\title{
WestVirginiaUniversity
}

THE RESEARCH REPOSITORY @ WVU

Graduate Theses, Dissertations, and Problem Reports

2015

\section{Intimate Empire: Women's Travel Writing and U.S. Imperialism 1880-1920}

Andrea Bebell

Follow this and additional works at: https://researchrepository.wvu.edu/etd

\section{Recommended Citation}

Bebell, Andrea, "Intimate Empire: Women's Travel Writing and U.S. Imperialism 1880-1920" (2015).

Graduate Theses, Dissertations, and Problem Reports. 5170.

https://researchrepository.wvu.edu/etd/5170

This Dissertation is protected by copyright and/or related rights. It has been brought to you by the The Research Repository @ WVU with permission from the rights-holder(s). You are free to use this Dissertation in any way that is permitted by the copyright and related rights legislation that applies to your use. For other uses you must obtain permission from the rights-holder(s) directly, unless additional rights are indicated by a Creative Commons license in the record and/ or on the work itself. This Dissertation has been accepted for inclusion in WVU Graduate Theses, Dissertations, and Problem Reports collection by an authorized administrator of The Research Repository @ WVU.

For more information, please contact researchrepository@mail.wvu.edu. 


\title{
Intimate Empire: Women's Travel Writing and U.S. Imperialism 1880-1920
}

\author{
Andrea Bebell \\ Dissertation submitted \\ to the Eberly College of Arts and Sciences \\ at West Virginia University \\ in partial fulfillment of the requirements for the degree of \\ Doctor of Philosophy in \\ English
}

Gwen Bergner, Ph.D., Chair

Cari Carpenter, Ph.D.

John Lamb, Ph.D.

Donald Pease, Ph.D.

Timothy Sweet, Ph.D.

Department of English

Morgantown, West Virginia

2015

Keywords: U.S. imperialism, travel writing, gender, race, suffrage, women's writing, empire Copyright 2015 Andrea Bebell 


\section{ABSTRACT \\ Intimate Empire: Women's Travel Writing and U.S. Imperialism 1880-1920}

\section{Andrea Bebell}

This dissertation examines how several turn-of-century U.S. women journalists and travel writers represent U.S. imperialism in a range of locales, trafficking in prevailing discourses of gender and race to represent colonized Others and as they engage in a comparative analysis to evaluate women's status in the U.S. In doing so, I suggest that these women, largely overlooked in critical discourses on U.S. imperialism, nonetheless contributed to the U.S. imperial imaginary. By recuperating the work of "newspaper ladies" Margherita Hamm, Nellie Bly, and Mary Krout, and through a reconsideration of Edith Wharton's travel writing, I consider the complex ways that white U.S. women negotiated the nexus of gender and race as consumers and producers of U.S. imperial ideology from 1880-1920. These texts reveal how white women utilized their white racial privilege to negotiate gender oppression at home and abroad. By exploring this subset of U.S. women's travel writing, I aim to examine the New Woman through a transnational lens, thus illuminating the intersection of empire, gender, and race at the dawn of what would be dubbed the American century. This study reveals the ways that white women utilized travel and text to foreground varying levels of commitment to the women's movement and to create alternate feminine identities and spaces for public and political engagement. In doing so, they often reify white racial privilege through their support for imperialism along with their utilization of social evolutionary theories, which posited white women as racially and biologically superior to non-white men and women. 


\section{Acknowledgements}

While writing about the travels of others, I embarked on my own journey. I wouldn't have made it very far in my travels through graduate school without the support and encouragement of my dissertation Chair, Gwen Bergner. We've been traveling partners for over eight years - from Colson Hall to Jamaica. She's led the way; and I've tried my best to keep up. Gwen, I'm forever grateful for your steadfast guidance, sharp criticisms, and professional mentorship. When I've stalled out, you've pushed me forward. When I felt too road-weary to continue, your tireless faith in me - and this project — kept me moving in the right direction. You're a model of professional and personal integrity that I can only hope to emulate. Thank you for being an incredible Chair, teacher, and friend.

I'd like to express gratitude to my entire dissertation committee: Cari Carpenter, John Lamb, Timothy Sweet, John Ernest, and Donald Pease. Your comments on drafts and our conversations about this project shaped this work for the better, and I'm very grateful for your time and attention to my growth as a scholar. Thank you for agreeing to be part of my journey.

I'm abundantly grateful for the faculty and staff in West Virginia University's Department of English. You've all — in ways big and small — made my path worth traveling. I'd especially like to acknowledge Professors Dennis Allen, Nathalie Singh-Corcoran, Laura Brady, Donald Hall, and Marilyn Francus. Along with my dissertation committee, you've all been instrumental in my development as a thinker and as a teacher. Thank you for leading by example. I'd also like to acknowledge the office staff who literally kept things moving smoothly during my time at WVU: Amanda Tustin, Cynthia Ulrich, Mary Vasquez, and Michele Marshall. Though some of you have moved on, you were a dream team, and I'm forever in your debt.

I'm also grateful for the friendship and camaraderie of my fellow doctoral students at WVU: Teresa Pershing, Jessica Queener, and Erin Johns Speese. To my “inner-circle": what a ride it's been! We've logged quite a few miles together-from the streets of Pittsburgh to the beaches of Mexico. We've celebrated each other's successes and we've commiserated over our disappointments. We've stood witness at each other's weddings and celebrated babies, and we've cried together at funerals. Thank you for your sisterhood, reassurance, and inspiration. You three have made this journey tolerable, and I can't wait to see where the road leads for each of us.

I owe a debt of gratitude to my 814 girls: Mary Feick and Theresa Gigliotti. Though we're separated by many miles, you've always been a source of encouragement and strength. We've come a long way since our shenanigans at PSU and on State Street. Thank you for keeping me grounded. I love you both.

This brings me to my constant traveling companion, John. I'm so grateful that you chose the empty seat next to me in our jazz class at Penn State thirteen years ago. I couldn't ask for a more supportive and loving partner in life. In all honesty, this work would mean very little if it weren't for you. In fact, it would likely have remained unfinished. You were kind when I needed kindness. You were generous in your encouragement when I wallowed in self-doubt. When the 
road got bumpy, you told me to buckle up and steer the course. Thank you for keeping your eye on the destination while I was lost in the journey.

Finally, I'd like to thank my mother and father, Marie and Donald Bebell. I can't begin to acknowledge all that you've sacrificed for my success. Dad-you always told me that you'd built a living "on your back," so that I could build one with my "brain." I hope I've made you proud. You've encouraged intellectual inquiry and instilled in me a deep respect for education and scholarship. At the same time, you taught me how to live with kindness, generosity, and love. You, like many good parents, told me that me that my options were limitless. Because of you both, I wasn't afraid to take a risk since I always had a safe place to fall. For this reason, and so many others, I dedicate this dissertation to you. 


\section{Table of Contents}

\section{Chapter 1}

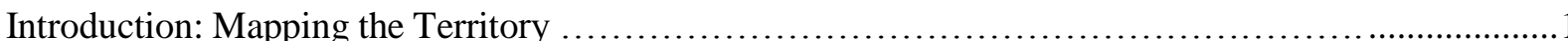

\section{Chapter 2}

The "Natural" Growth of the Republic: Race, Gender, Sex, and Science

in the Writing of Margherita Arlina Hamm.

\section{Chapter 3}

Little Ladies Locate the Pacific: Mary Krout's Alice's Visit to the Hawaiian Islands and U.S. Imperialism in Turn-of-the-Century Children's Geography Primers....

\section{Chapter 4}

"A Free American Girl”: Gender, Race, and Economic Empire in

Nellie Bly's Six Months in Mexico.

\section{Chapter 5}

Into the Bled: Edith Wharton's Islamic Morocco. 127

Conclusion .161

Notes .166

Works Cited. .189 


\section{Chapter 1}

Introduction: Mapping the Territory

In 1896, just a few days following her extensive coverage of the National Women's Suffrage Convention in Washington, D.C., Nellie Bly interviewed Susan B. Anthony for The New York World. Bly had become famous ten years earlier for her record-breaking trip around the world. The tenor and tone of the interview suggests that Bly was meeting one of her heroines. Almost gushing, Bly writes, "Susan B. Anthony! She was waiting for me. I stood for an instant in the doorway and looked at her" ("Champion" 131). Within moments of meeting, Anthony reveals, "I haven't read a newspaper in ten days and I feel lost to everything. Tell me about Cuba! I am so interested in it. I would postpone my own enfranchisement to see Cuba free" ("Champion" 131). At the time of the interview, the Spanish-American War was still two years away, but the question of liberating Cuba from Spanish control was a conversation point among suffragists and other Americans. Anthony's desire for Cuban liberation (even in place of her own, as she says) suggests that the U.S. women's movement was engaged with international politics and, moreover, that women viewed their fight for the vote as not unlike the struggle of foreign others to free themselves from colonial domination. Bly's interview with Anthony provides one glimpse into the complex relationship between U.S. women's rights and U.S. imperialism at the turn of the twentieth century. But just as suffragists differed on the rationale and strategies for gaining the vote, they also held varying views on U.S. continental and territorial expansion at the turn of the twentieth century. My project examines how several late nineteenth and early twentieth century U.S. women journalists and travel writers represent imperialism in a range of locales, trafficking in prevailing discourses of gender and race to represent colonized Others and engaging in a comparative analysis to evaluate women's status in the U.S. In doing so, I suggest that these 
women, largely overlooked in critical discourses on U.S. imperialism, nonetheless contributed to the U.S. imperial imaginary. ${ }^{1}$

By recuperating the work of "newspaper ladies" Margherita Hamm, Nellie Bly, and Mary Krout, and through a reconsideration of Edith Wharton's travel writing, I consider the complex ways that white U.S. women negotiated the nexus of gender and race as consumers and producers of U.S. imperial ideology. U.S. empire building was not exclusively a masculine activity despite the pervasiveness of the ideology of separate spheres within U.S. culture. Often women found their way into writing about empire by addressing the domestic spaces of empire. In fact, Ann Stoler argues that U.S. women's writing on empire blurs distinctions between the domestic and the foreign (“Tense and Tender Ties” 24). According to Stoler, U.S. women focused on "the intimate frontier" of empire, that is the "social and cultural space where racial classifications are defined and defied, where relations between colonizer and colonized could powerfully confound or confirm the strictures of governance and categories of rule" ("Tense and Tender Ties" 24). These spaces include the home, hospital, school, institutions for public hygiene, and the actions that take place therein like marriage, sex, illness, education, and laws that governed such areas of daily life. Through a discursive construction of the intimate frontiers of U.S. empire, U.S. women contributed to the biopolitical governance of U.S. territorial possessions and spheres of influence.

The range of texts and authors I examine suggests the breadth and depth of U.S. white women's participation in the discourse of U.S. imperialism between the years of 1880-1920, a period typically considered the height of U.S. extraterritorial expansion. Since this study focuses only on the writing of white women, it does not encompass the whole range of U.S. women's writing on empire. Nor are these authors solely concerned with the politics of empire. 
Rather, they explore the complex relationships among national expansion, gender, and race. As a group they represent white, middle-class women who mostly favored U.S. imperial endeavors. These women reveal how white women utilized their white racial privilege to negotiate gender oppression at home and abroad. By exploring this subset of U.S. women's travel writing, I aim to examine the New Woman through a transnational lens, thus illuminating the intersection of empire, gender, and race at the dawn of what would be dubbed the American century. ${ }^{2}$ This study reveals the ways that white women utilized travel and text to foreground varying levels of commitment to the women's movement and to create alternate feminine identities and spaces for public and political engagement. In doing so, they often reify white racial privilege through their support for imperialism along with their utilization of social evolutionary theories, which posited white women as racially and biologically superior to non-white men and women.

\section{An Occluded History: U.S. Women and U.S. Imperialism}

The publication of Donald Pease and Amy Kaplan's landmark Cultures of United States Imperialism in 1993 marked a paradigm shift in American Studies. The collection of essays considered how U.S. imperialism shaped "the multiple histories of continental and overseas expansion, conquest, conflict, and resistance which have shaped the cultures of the United States and the cultures of those it has dominated within and beyond its geopolitical boundaries" (Kaplan, "Left Alone" 4). Pease and Kaplan sought to disturb the master narrative of American exceptionalism, supported by notions of manifest destiny, which elided the histories of U.S. imperial aggression in terms of both contiguous and extraterritorial expansion. In histories of U.S. nation building, the process of continental expansion throughout the eighteenth and nineteenth centuries was long considered a separate and distinct phenomenon from European imperialism. Even those who are reluctant to acknowledge the United States' long history of 
continental aggression typically acknowledge the Spanish-American War, and its aftermath, as a watershed moment of U.S. imperialism. Following the war, the Treaty of Paris (1898) laid out America's new imperial possessions; Spain surrendered control over Cuba and ceded Puerto Rico, along with parts of the Spanish West Indies, the island of Guam, and the Philippines to the United States. In the same year, the U.S. also annexed Hawaii. I argue, like Pease and Kaplan, that 1898, while a key moment in the history of American empire, was part of an "expansionist continuum," which existed since the nation's creation (Kaplan, "Left Alone" 17). The “expansionist continuum," which still persists today, involved more than annexing or occupying new geographical territories. Discussions of U.S. imperialism exceed straightforward considerations of foreign policy or economic relationships based upon market demand, though these are certainly important aspect of U.S. imperialism. Rather, students and scholars of U.S. imperialism must consider how notions of "abroad" shaped domestic cultures at home. How did imperial relations shape notions of national belonging? How were such relations supported and challenged within the U.S.?

Despite the growing scholarship on U.S. imperialism, we still know comparatively little about U.S. women's involvement in U.S. imperialism following the Spanish-American war. Scholars, including Anne McClintock, Laura Donaldson, Sara Mills, and Anne Stoler have studied the intersections of gender and empire within the context of European imperialism. Importantly, these scholars established that empire-building, whether British, American, or otherwise, was not solely a masculine endeavor. In her foundational study of gender and imperialism, McClintock asserts that "women and men did not experience imperialism in the same way" (5). Additionally, women, far from a coherent group, experienced imperialism in different ways based upon their racial and class statuses. Both British and U.S. colonial women, 
usually white and middle-class, were "ambiguously placed" in the imperial infrastructure but still played important roles in the consolidation of empire abroad. Usually, women had little to do with the military aspects of empire-building, but were important consumers, creators, and defenders/objectors of imperial ideologies.

In the case of British settler colonies, colonial women were actually charged with making the imperial house a home, thereby "marking the boundaries" of domestic and foreign (McClintock 29). The colonial spaces of India or Africa were transformed, through the presence of white women in the colonies, to "a theater for exhibiting...the cult of domesticity" (McClintock 17). Moreover, Victorian women who remained in England played an equally important role in consolidating empire through their consumption of imperial goods. The work of McClintock and others clearly demonstrates the ways that women negotiated the territory of empire-building, but it also reminds us that gender is not an isolated area of analysis.

Constructions of gender, within the imperial context, consistently depended upon constructions of race, class, citizenship, and nation. For instance, discourses of British and U.S. imperialism often solidified white women's already privileged racial status, thus offering opportunities for agency within the spaces of empire that were not available at home.

Though U.S. women's involvement in U.S. imperialism has been less theorized than British women's participation in empire, Amy Kaplan, Etusko Taketani, Mari Yoshihara, Gail Bederman, Kristin Hoganson and others have considered the role of U.S. women in U.S. imperial initiatives during the nineteenth century. Kaplan's work on "manifest domesticity" is likely the most fully developed theorization of U.S. women and their participation in U.S. imperialism. Kaplan shifts our focus on manifest destiny as a driving force of U.S. empire, and places U.S. women as central to empire building processes. Kaplan uses the notion of "manifest 
domesticity," or the "imperial reach of the domestic sphere," to interrogate the ideology of separate spheres within the construction of empire during the 1840s and 50s. Generally, the ideology of separate spheres "configures the home as a stable haven or feminine counterbalance to the male activity of territorial conquest" (Kaplan, Anarchy 25). Kaplan argues that these gendered spheres were intricately intertwined. Rather than a binary opposition to territorial conquest, the "home" was a "mobilizing outpost that transformed conquered foreign lands into the domestic sphere of family and nation" (Anarchy 25). Kaplan looks to examples such as Katherine Beecher's Treatise on Domestic Economy to locate spaces where the language of empire was immersed within discourses of domesticity. The concept of domesticity posited the nation as home (and home as nation) at a time when territorial boundaries were expanding exponentially through violent confrontations with indigenous populations.

Also working within the first half of nineteenth century, Taketani builds upon Kaplan's formulation of "manifest domesticity" to explore alternative visions of territorial expansion fashioned by U.S. women. Taketani also takes the domestic as an important point of analysis; however, Taketani warns against the monolithic impulse in deployments of "manifest domesticity" as a way to "explain" U.S. women's involvement in U.S. imperialism. Instead, Taketani suggests that "the agency of women in U.S. imperialism may not fully be accounted for without a consideration of the negotiatory process in which women engaged in prior modes of colonialism operating in different parts of the world" (92). Moreover, special attention to geographical context explains the varying attitudes among U.S. women in relation to U.S. territorial expansion. Taketani's call for more location-specific analysis of women's involvement in empire is answered in works like Yoshihara's Embracing the East: American Women and Orientalism (2002) and Laura Briggs's Reproducing Empire: Race, Sex, and US Imperialism in 
Puerto Rico (2003). What these works suggest is that U.S. women held varying attitudes toward U.S. empire-building. Some supported expansion, while others argued against it, and some remained ambivalent.

Kaplan's “manifest domesticity,” along with Taketani’s insistence on location specificity, both highlight the ambivalence lurking within seemingly absolute terms like "domestic" and "foreign." As Kaplan asserts, in common uses, domestic is shorthand for nation and is the binary opposite of foreign. Domestic and foreign, then, are important markers of inclusion and exclusion in regards to who is part of the domestic nation and who is not. But as Kaplan, McClintock, and others point out, the distinction between domestic and foreign is not absolute. Rather than seeing imperialism as the one-way deployment of power, Kaplan asserts that foreign politics shaped national (i.e., domestic) culture. International struggles for imperial supremacy influenced “domestic metaphors of national identity” (Kaplan, Anarchy 2). Moreover, international conflict led to public debates over who is entitled to national membership. Debates over national belonging implicitly and explicitly reveal U.S. anxieties over gender, race, and citizenship. Women travelers, as McClintock notes, were in many ways boundary markers between the domestic and foreign.

My dissertation considers how each author, in each place, articulates the relationship between the domestic space of the nation and the foreign space of their chosen locales within the historical context of U.S. imperialism. I utilize Kaplan's paradigm of manifest domesticity as a way of discussing U.S. empire-building, while accounting for the unique locational specifics of each place, as Taketani suggests. I argue that each author depicts the "foreign" in an attempt to not only to transform "conquered foreign lands into [a] domestic sphere," but to also consolidate and question domestic policies in the U.S. (Kaplan, Anarchy 25). 
In the aftermath of the Spanish-American War, the U.S. worked to define its relationship (politically, socially, and culturally) to its new territories. The binary rhetoric of "domestic vs. foreign" infused political debates over which foreign places to include within the domestic national body politic and, if included, in what capacity (e.g., as an incorporated or unincorporated territory). The U.S. struggled to determine and define the fate of the foreign populations of these places. Questions about "fitness" of foreign populations to assimilate to U.S. culture or self-govern, along with public debates over territorial expansion of the U.S., prompted what is now known as the 1901 Insular Cases. The Insular Cases were a series of Supreme Court decisions that dictated whether or not newly-acquired territories were awarded rights and protections under the U.S. Constitution. The doctrine of incorporation posited that only incorporated territories, like Hawaii and Alaska, would be granted Constitutional rights. Spaces that remained "unincorporated," like the Philippines, Puerto Rico, and Guam, were awarded only partial Constitutional rights. The Supreme Court case of Downes vs. Bidwell, which Kaplan reviews in her work, is instructive here regarding the inclusion (or exclusion) of newly acquired territories in the domestic space of the nation. The case considered the status of Puerto Rico in regards to U.S. tax and tariff laws. Ultimately, Justice Edward Douglas White concluded that Puerto Rico was both domestic and foreign; in his opinion, Puerto Rico was not "a foreign country" in an international sense because the U.S. held possession over the island. At the same time, Puerto Rico "was foreign to the United States in a domestic sense" because the island was not incorporated into the U.S. (qtd. in Kaplan, Anarchy 3). From this perspective, Puerto Rico was neither domestic nor foreign and, somehow, both domestic and foreign. For Kaplan, the language of this opinion ("domestic in a foreign sense") demonstrates "an unstable paradox at the heart of U.S. imperial culture" (Kaplan, Anarchy 3). Domestic and foreign, then, become 
metaphors "imbued with racialized and gendered associations of home and family, outsiders and insiders, subjects and citizens" (Kaplan, Anarchy 3).

More than simple metaphors, the domestic/foreign paradox assisted the U.S. in managing its new possessions. The possessions, and spheres of influence, could be both foreign and domestic (or "domestic in a foreign sense"). Homi Bhabha's work on colonial stereotype and ambivalence is instructive here. Bhabha argues that the colonial fantasy "proposes a teleology," which posits that "under certain conditions of colonial domination and control the native is progressively reformable" (171). “On the other hand," Bhabha continues, this teleology "effectively displays the 'separation"” between colonial self and native other-a separation that denies the colonized "the capacities for self-government, independence, Western modes of civility" (171). In other words, Bhabha explains that the distinction between self/other (colony/metropole or domestic/foreign) within the colonial context relies upon a certain ambivalence, which posits that colonial others are both capable and incapable of Western reforms. In the context of U.S. territories, to borrow from Bhabha, the domestic/foreign paradox represents a similar type of colonial ambivalence. This time, though, "reform" has a direct relationship to citizenship.

While the specifics vary in each location, I maintain that this domestic/foreign paradox exists across much of women's writing about U.S. imperialism at the turn into the twentieth century. I argue that Hamm, Krout, Bly, and Wharton each "domesticate" foreign spaces, thus making these places knowable to U.S. readers. At the same time, even in the case of annexed territories like Hawaii, these places ultimately remained exotic and foreign. Each author I discuss considered her writing a performance of civic duty to make Americans "aware" of the geopolitical prowess of the United States. Moreover, the image of the traveling white woman 
itself became a domesticating force within these narratives of U.S. expansion. The ability of a woman to travel without a male chaperone suggested the extent to which these places were already domesticated (i.e., safe).

In this dissertation, I consider several geographical sites of U.S. imperialism that challenge the domestic/foreign binary. I also challenge traditional views of imperialism, which posit that imperialism only exists where one country establishes a formal colony abroad and exercises "absolute" power. I consider representations of sites of formal U.S. empire-building such as Hawaii, the Philippines, and Puerto Rico. Yet I also consider sites of informal empirewhere U.S. power dynamics were less easily defined, such as Mexico and Morocco. Mexico, the closest "foreign" neighbor to the United States, was a site of intense U.S. economic imperialism at the turn into the twentieth century. Morocco, a French colony at this time, may seem far removed for U.S. imperialism, but Morocco indeed held a place within U.S. imperial fantasies through the long-running discourses of American Orientalism.

Margarheta Arlina Hamm, the self-proclaimed "first female war correspondent," wrote extensively about America's possessions and "spheres of influence." She began her career as a foreign correspondent by reporting on the Sino-Japanese War. Throughout her career, she traveled to the Philippines, China, Korea, Japan, Puerto Rico, and Cuba. In her work following the Spanish American War, she made an explicit case for national growth by advocating, to use President McKinley’s phrase, “benevolent assimilation” and territorial occupation in the Philippines. Hamm mapped "the routes to the Philippines" making a case for "how closely the world [is] tied up together" (Manila and the Philippines 9). The Philippines, along with Puerto Rico, Guam, and to an extent Cuba, fell under U.S. control following the Spanish-American War. Once the U.S. purchased the Philippines from Spain, the U.S. asserted military control over 
the islands, which resulted in a bloody conflict between the U.S. military and Filipino revolutionaries, which "officially" lasted from 1898-1902 (now called the American-Filipino War). For the U.S., the Philippine islands offered a strategic military and commercial outpost in the Pacific and offered a route toward the fabled Chinese markets. Clearly Hamm saw the commercial potential of the Philippines, and dedicates much of her writing to explaining the rich natural resources and their export potential. Hamm deployed racialized descriptions of Filipinos using discourses of scientific racism to in order to argue that the majority of Filipinos remained too savage for U.S. citizenship. Therefore, Hamm sought to domesticate the Philippines as an area for U.S. occupation and economic growth, while maintaining that the people who inhabit the archipelago ultimately remain foreign and unable to assimilate.

Mary Hannah Krout, a school teacher turned newspaper lady, brought foreign affairs into the domestic space of the U.S. schoolhouse. Krout traveled throughout the "American Pacific" and published two book-length accounts of Hawaii-U.S. relations. After reporting from the "front-lines" of the "Hawaiian Revolution," she published her collected dispatches in Hawaii and Revolution (1898). The "Hawaiian Revolution" was the name assigned to the forceful U.S. overthrow of the Hawaiian monarchy in 1893, thus solidifying U.S. political control over the Islands. Formal annexation came in 1898 following the Newlands Resolution, which assigned Hawaii the status of "unincorporated territory." The Resolution denied Hawaii the advantages of U.S. statehood and withheld U.S. citizenship from Hawaiians. The U.S. did not grant Hawaii statehood until 1959. After Krout's return to the states, she adapted Hawaii and Revolution for a new audience: U.S. school children. In the preface to her children's geography primer Alice's Visit to the Hawaiian Islands (1900), she states that "it is important that children in our schools should learn something of the geography of these islands, and of the manner, customs, and 
history of the people who inhabit them" since "the Hawaiian Islands have now become part of the United States" (7). Krout's phrase "part of the United States" carries domestic connotations but effaces and simplifies the reality and brutality of Hawaiian annexation. Alice's Visit white washes the imperial overthrow of the Hawaiian monarchy and explains that prior to U.S. annexation, Hawaii, while rich with natural resources, was a diseased and savage waste-land.

Alice's Visit, and other geography-based texts, raise questions regarding the discursive creation of an "American Pacific.” As John Eperjesi notes, geographies are never natural regions. Instead, the creation of a geographical region is a political act "by which ruling classes, races, or nations secure their power...by making a particular way of mapping the world appear natural" (16). Alice's Visit indoctrinates U.S. schoolchildren in the geographical creation of the “American Pacific," of which Hawaii was the "jewel." To do so, Krout presents U.S. annexation of Hawaii as a civilizing mission that upholds the efficacy and necessity of U.S. annexation to the mutual benefit of both U.S. citizens and Hawaiians.

At the end of the nineteenth century Mexico lacked a formal colonial relationship with the U.S.; however, due to its close geographical proximity, the U.S. always maintained an economic and political interest in Mexico. Therefore, Nellie Bly's Six Months in Mexico (1888) reflects a different sort of imperial relationship to the U.S. - a soft imperialism. Following the Mexican-American War, the U.S. claimed huge portions of Mexican territory, but, by the time Bly traveled there in 1886, formal annexation of Mexican territory had officially ceased. However, U.S. political debates regarding further claims on Mexican territory (all or in part) played out in the popular press well into the early twentieth century, thereby leaving open the possibility of future territorial expansion. Though it did not annex additional Mexican territory, the U.S. exercised policies that ensured the "economic domination" of Mexico, thus securing 
Mexico within U.S. spheres of influence (González 16). Bly’s text demonstrates that Mexico loomed large in the imperial imaginary as a space for future U.S. economic development. Bly confidently asserts that in the future Mexico will serve as a new "California" through U.S. economic domination and cultural influence (Six Months 224). Bly promotes this imperial fantasy while also criticizing the regime of Mexico's president, Porfirio Diaz, who was wellliked by U.S. industrialists for his "open-door" policy toward U.S. investment. Bly sees the repugnant condition of Mexico's poor as evidence of Diaz's failing presidency, despite his open attitude toward U.S. economic intervention in Mexico. So Bly emerges as both a supporter of U.S. influence in Mexico and an objector to pro-expansion industrialists who unabashedly supported Diaz.

Edith Wharton's travel guide In Morocco (1920) sheds light on another sort of U.S. imperial fantasy, which she expresses through the discourse of American Orientalism. Wharton polices U.S. domestic space against perceived threats of Islam. Wharton does not discuss a territory within the U.S. empire, but her text highlights the international dynamics of Orientalist discourse and how this discourse articulated the need to protect the U.S. nation from intrusions of the foreign within domestic borders. Specifically, French Morocco emerges not as a site for overt U.S. imperialism or annexation but as a fantasy of Muslim incursion in U.S. culture. Since Morocco was a French protectorate at the time of Wharton's visit, In Morocco suggests the ways that French empire building impacted U.S. popular and political culture. U.S. possession over Hawaii and the Philippines, along with U.S. economic control of Mexico, provide more straightforward examples of U.S. imperialism in action. But Wharton's work reflects the functions of American Orientalism filtered through the lens of French colonialism. 
Bebell 14

\section{Race and Gender in the Context of U.S. Empire}

This project examines how a group of select U.S. women journalists and travel writers performed the "labor of race" at home and abroad at the turn into the twentieth century in the service of U.S. expansionism and empire-building. David Goldberg defines the labor of race as "the hard work, conceptually and materially, socially and politically, legally and forcefully, it took to set up and reproduce racial arrangements within a society" (3). Goldberg maintains that the labor of race is so subtle and constant that it often goes undetected, thus making racial inequality seem like a natural epistemological truth. By the late-nineteenth and early twentieth century, the racial climate in the United States reflected legacies of slavery, the prevalence of Jim Crow's "separate but equal" doctrine, anti-miscegenation laws, the final suppression of Native Americans, and stringent immigration regulations that assigned racial statuses to immigrants or enforced strict immigration quotas or bans depending on the presumed "fitness" of a particular ethno-racial group. Debates over political participation, social equality, U.S. citizenship, and national belonging almost always revolved around categories of race. Racial categories, then, were never just mere "legal" distinctions; racial categories dictated social, political, and citizenship distinctions. Laws that govern citizenship, such as the Jim Crows laws and the immigration acts of this period, provide the backdrop for understanding the complex racial dynamics of U.S. expansionism during this period. Yet domestic politics did not merely influence the management of new territories abroad; the management of new territories also shaped domestic politics as well. Together, these laws and regulations deployed at home and abroad, in theory and practice, "forged images, histories, and narratives that place, displace, and replace individuals in relation to the national polity... and powerfully shapes who the citizenry is" (Lowe 2). The United States' imperial ambitions at the turn of the twentieth century put these 
issues in stark relief, thereby challenging what constituted citizen/subject, home/abroad, and domestic/foreign. $^{3}$

As the U.S. approached the twentieth century, Americans were confronting "foreigners" on at least two fronts: at home and abroad. Twenty-six million immigrants entered the U.S. between 1870 and 1920 (Jacobson 61). This rise in foreign populations raised two concerns for many Americans. The first was whether American workers would survive foreign labor competition (especially during the economic depression of the 1880s). Second, growing antiimmigrant sentiment had "given voice to profound misgivings of absorbing so many 'unassimilable' strangers" (Jacobson 61). U.S. discourses regarding assimilation were intimately tied to conceptions of race. The racial categories in play at the turn of the century were rigid and unforgiving, while remaining mutable and fluid. The "one drop rule still held sway," as did the black/white binary, but Americans had difficulty placing many new immigrants within contemporary racial schemas. David Roediger reports that by 1888 "scientific authorities" estimated that there "were between two and sixty-three races" in existence (11). Legal definitions of "white" racial status shifted throughout the years of the nineteenth century, though racial hierarchies, which placed whites in a position of power over those deemed "non-white," remained staunchly intact. But what of those who inhabited the newly acquitted territories following the Spanish-American War, or those who were crossing the U.S./Mexico border as laborers? Or even those racial others in places like North Africa that loomed large in the American Orientalist imaginary?

This study examines how white U.S. women performed the labor of race within the context of U.S. imperialism through various publications loosely termed "travel writing." The writers I examine made foreign "races" legible to a U.S. audience by drawing on available and 
established U.S. racial categories. I'm guided by the following questions: what sort of currency did U.S. white women have in the symbolic economy of U.S. imperialism? How do intersections of racial and gender identities function to shape the ideologies and strategies of U.S. empirebuilding at the turn into the century? How did white women's convictions regarding race shape their gender politics at home and abroad? And, conversely, how did white women's gender politics interact with their racial ideologies and attitudes toward U.S. expansion? This set of questions necessitates examining both "whiteness" and "U.S. womanhood” as socio-ideological and historical constructs created in the midst of already established power hierarchies in the U.S. I share Reina Lewis and Sara Mills's call to deconstruct the inner-workings of whiteness in the colonial context, "rather than assuming that race is a term which can only be used in discussions about Black people" (8). The texts I examine offer opportunities to observe what Vern Ware calls the "machinations of white supremacism" in locales essential to consolidating U.S. empire (Out of Whiteness 2). ${ }^{4}$

U.S. women's opinions about empire and expansion varied. Some supported U.S. imperialism, while others were vocal critics. No matter their particular position regarding imperialism, women "were central actors" in empire-building at home and abroad (Coloma 244). Those who traveled abroad served an important symbolic function; they signaled "American womanhood," which was almost always conceived of as white and middle class. Yoshihara notes that U.S. women were important symbols of national identity and "guardians of American nationalism" (4). Roland Sintos Coloma, working within the context of the U.S. occupation of the Philippines, uses the term "imperial feminist" as a way to signal white women's mutual interest in gender equality, racial subjugation, and expansion. Building upon the work of Valerie Amos and Pratibha Parmar, Coloma contends that "white women as imperial feminists asserted 
their principle crusade and superiority over white men and brown women becoming bearers of racialized heteronormative traditions and feminine respectability and becoming barriers to interracial sexual relations" (243).

While Coloma's "imperial feminist" is a useful term for understanding the intersection of gender, race, and empire, it remains too totalizing to encapsulate the activities of all U.S. women abroad. Additionally, as Yoshihara points out, the image of the "white American woman" was itself an ideological construction, which benefited white males (5). Not all women who traveled to U.S. territories or spheres of influence necessarily identified as feminist. For example, Edith Wharton remained ambivalent on the issue of suffrage. Additionally, not all women who traveled to U.S. territories or spheres of influence identified with Victorian notions of femininity. Nellie Bly, a self-professed tom-boy, vocally rejected such notions. Therefore, it is counter-intuitive to apply the broad term of "imperial feminism" to all U.S. women's activities abroad.

White women would often assert transnational moral and racial superiority to regulate and discipline the behaviors and bodies of non-white others through an emphasis on the intimate aspects of imperialism. This is not to say that U.S. women did not report on the "masculine" business of empire (e.g., military and economic discourse). They certainly did. For instance, Hamm emphasizes the economic advantages of U.S. imperialism in her Manila and the Philippines and America's New Possessions and Spheres of Influence. However, more often than not, U.S. women's representations of foreign others included depictions of domestic space and intimacies contained therein. I agree with Stoler's assertion that representations of the home, sexual arrangements, marriage structures, child rearing, bodily health, etc. all play a crucial role in the biopolitical governance of imperial spaces. Furthermore, as a method of "intimate surveillance," these representations contribute to the comparative racialization of colonial 
subjects (Stoler, Carnal Knowledge xvi). Hamm, Krout, Bly, and Wharton focus on one of the central facets of the intimate: the foreign family. The family — whether on the streets of Mexico or in the Moroccan harem-is an "axis of colonialism" (Briggs 5). These authors, in fact, pathologize the "foreign family" as abject sites of racial mixing, sexual deviance, and disease. They then cite these intimate pathologies as evidence of racial, cultural, and national inferiority. Hamm's Manila and Philippines (1898) is an almanac-like volume written during the final months of the Spanish-American War. Throughout the volume, Hamm utilizes scientific racism to elucidate the practice of "racial mixing" and the presence of "half-breeds" in the archipelago. She identifies and creates racial categories ranging from "the Spanish Malay halfcaste" to the "Chino-Spanish half breed" throughout the text (Manila and the Philippines 23). By presenting the Philippines as "a battleground of many races," Hamm enforces order upon the racial chaos of the Philippines as a form of colonial management and as evidence of her "scientific" expertise (Manila and the Philippines 22). While many Western travelers blamed the licentiousness of native women for the presence of "half-breeds," Hamm instead deploys a critique of colonial men's sexual transgressions. Half-breeds, Hamm writes, "represent the unrighteous living of the men who make the declaration" (Manila and the Philippines 23). From this perspective, Hamm's role within the imperial machine as a white woman is in the policing of sexual boundaries between colonial men and native women — an abject domestic arrangement. Hamm nearly overlooks the Chinese practices of polygamy, concubineage, and miscegenation; however, she condemns Spanish men (usually colonial functionaries) for their sexual liaisons with native women and their lack of paternal responsibility. Moreover, Hamm asserts that it is the children of such liaisons that truly suffer the consequences. She concludes that "the men become gamblers and the women usually drift to the ranks of the lost" (Manila and the 
Philippines 42). In her genteel way, Hamm argues that the daughters of these relationships most likely become prostitutes, thus perpetuating racial mixing through illicit sexual practices.

In her children's geography primer Alice's Visit to the Hawaiian Islands (1900), Krout provides U.S. schoolchildren with an imperial education that supports U.S. annexation. In doing so, Krout provides a historiography of U.S.-Hawaii relations that effaces the brutality of colonization in favor of a narrative that celebrates the United States' role in Hawaii's "evolution" from barbarism to civilization (Alice's Visit 7). She contrasts the clean, sanitary Hawaii that Alice visits with stories of pre-annexation Hawaii's purportedly savage customs and mistreatment of women and children. By the time Alice visits Hawaii, there is already evidence of the United States' “civilizing” force via colonial management evidenced by Hawaii's clean streets, happy natives, along with the presence of so many Americans already on the islands. Yet the specter of Hawaii's barbarous past lurks throughout the primer-particularly in the images of child abuse, tropical disease, and contagion. In sections of the primer such as "Some Hawaiian Customs" and the "The People of Hawaii," Krout depicts pre-annexation Hawaii as a space of not only unbearable cruelty to native women and children, but as a space overrun with leprosy and other communicable diseases. She touts U.S. efforts at the containment of such diseases and the banishment of cruel practices and traditions. Ultimately, Alice's Visit interpellates U.S. schoolchildren as miniature imperialists with a special emphasis on Hawaii as a space for a young American girls, like Alice, to come of age.

Nellie Bly both supports and subverts traditional discourses of U.S. imperialism toward Mexico during the late nineteenth century, thus mixing domestic and foreign concerns over women's rights, cross cultural patriarchies, racialization, and economic imperialism. In Six Months in Mexico (1888), Bly crafts her public persona as "an American girl” in Mexico in order 
to demonstrate by example the ability and independence of women in the U.S. In this way, Bly was always a participant in her own story, which was a common facet of "girl stunt reporting," a genre that made Bly famous in the late-nineteenth century. Given her understanding of and frustration with gender oppression, Bly wages a critique of the Mexican government, under the direction of President Diaz, that focuses on the lives (and deaths) of Mexico's indigenous poor women and children. In doing so, she creates a cross-cultural comparison of politicallysanctioned patriarchies wherein she advocates on behalf of Mexican women and children, thus using the "Mexico example" to highlight the inequities of U.S. gender politics. Bly carefully outlines Mexican marriage and reproductive habits, wherein women are expected to bear more children than they are able to support, thus bolstering U.S. views that Mexican's had a tendency toward over-population thereby making them unable to assimilate to U.S. culture. Mexican children, Bly contends, are apt to die before maturity due to diseased-filled streets, lack of nutrition, and an absence of proper parenting. While Bly is sympathetic toward the domestic constraints placed upon Mexico's women, she nonetheless racializes Mexican bodies and renders Mexico's poor as bare-life. As a result, Bly reveals the unevenness in which U.S. women, though victims of U.S. patriarchy, maintained racial superiority over non-white women, which is evident in Bly's reduction of Mexican women to bare-life status. Here, Bly's identification with and against Mexican women suggests a problem inherent in discourses of (proto)transnational feminism. Bly universalizes female experience of patriarchal oppression, while perpetuating myths of white racial superiority.

Edith Wharton's observations in her travel guide In Morocco (1920) demonstrate how religious identity/affiliation impacted categories of race, gender, and imperialism. Wharton describes Islamic Morocco as a modern "death world" and uses necropolitical narration to 
suggest the living dead status of Moroccans who continue to observe the violent, backward, and misogynist religious practices, such has blood-rituals and harem seclusion. In her description of Islamic traditions, Wharton's criticism of Islam takes on a distinctly racial tone. Wharton creates a discursive link between death, violence, race, and Islam. To this end, Wharton reports on the intimate, domestic space of the Moroccan harem in a chapter titled "Harem and Ceremonies." For Wharton, the harem is anti-domestic racialized space that stands in stark contradiction to Western-style marriage and monogamy. The certainty of Wharton's assertions regarding the racial degeneracy of the harem is abruptly disturbed when she encounters a "French" harem girl, who, for Wharton, racially reads as "white." Wharton's horror at seeing a "white" harem woman reflects the fear/fantasy of white sexual slavery that loomed large in American Orientalist imaginary. Since the times of the Barbary captivity narratives, stories of "white slaves" held by Muslim "masters" circulated in the West. But moreover, Wharton's anxiety at both her own racial identification with the "white" harem girl reflects not only the mythological status of white slaves, but also contemporary discourses of "white slavery" and prostitution, which were playing out in the British and American presses since the mid-nineteenth century. Wharton's work reflects a second concern as well: the foreign threat of Islam in the domestic space of the United States. As part of the socio-political concerns over growing immigrant populations, there was a palpable social anxiety regarding a covert or secret Muslim population in the U.S., or as one 1911 newspaper called it "The Moslem Menace."

\section{Recovering the Past: Recuperating Women's Writing on U.S. Empire:}

While current scholarship has refuted the "exceptional" status of U.S. imperialism, we still have an incomplete picture of the complexities and nuances of the processes and participants in U.S. empire building at the turn of the twentieth century. Since U.S. women's writing about 
U.S. imperialism remains vastly understudied, I've recovered the work of female writers that has until now has gone largely unnoticed in the fields of literary scholarship and American Studies. ${ }^{5}$ In some ways, scholars' lack of engagement with U.S. women's writing about (and roles within) U.S. imperial processes suggests that "in the academic sphere as far as literary criticism is concerned, still only minimal attention to paid to the work of women writers" (Kietrys and Linares 47). Recuperative studies like this have the potential to destabilize, complicate, and challenge the metanarratives of U.S. historical memory. As may be evident at this point, Margarheta Hamm, Mary Krout, and Nellie Bly were prominent journalists at the turn of the twentieth century with national syndication in some of the nation's best-known papers, including Joseph Pulitzer's New York World and the New York Journal. Each traveled abroad and wrote extensively on domestic and foreign politics from their perspective as white U.S. women. Their near invisibility today is almost surprising. Their absence suggests not only a gap in our understanding of the myriad ways that white women participated in U.S. empire-building, but it also suggests that we know very little about turn-of-the-century women's journalism. ${ }^{6}$

Nellie Bly, born Elizabeth Cochrane, was, and continues to be, the best known of the group for her record-breaking (and highly publicized) trip around the world in 1890 . The rest of her writing, including (or maybe especially) Six Months is Mexico, remains mostly unacknowledged by historians and literary critics. Six Months in Mexico, Hamm's Manila and The Philippines and America's New Possessions and Spheres of Influence, along with Mary Krout's Hawaii and a Revolution and Alice's Visit to the Hawaiian Islands, began as newspaper articles. So, why have these writers been overlooked? A primary reason is that the genres of travel guides, newspaper writing, and children's educational literature have been viewed as subliterary genres. As Alice Fahs notes, "Despite reaching an extensive audience and despite 
offering a host of innovative features that even included fiction, mass-circulation newspapers have rarely been considered a form of popular literature to be studied on par with magazines and books" (10). Among the reasons for neglect of turn-of-the-century newspapers, Fahs discusses the "genteel attacks on [journalistic] sensationalism" that contemporary book and elite magazine publishers waged. Their logic went something like this: newspapers were flashy, tawdry, low brow, and, fundamentally, unliterary. Fahs surmises that this attack on popular newspapers had long-lasting consequences, extending to their continued disparagement by scholars today. But turn-of-the-century newspaper writings, particularly by women, offer a wealth of insight regarding women's engagement in the public sphere, and the discourses they crafted to express concerns over gender equality, suffrage, and international politics as they experienced them.

Children's geography primers, a subgenre of children's literature, are also understudied. However, cultural and literary studies scholars have recently begun to address children's literature as a serious source of information on the creation of national culture and the sociopolitical ideologies that sustain it. Taketani, one of the few scholars that consider children's primers, makes that point that children's geographies are part of a "patriotic genre" that indoctrinates U.S. school children regarding the rules of U.S. national boundaries and membership. ${ }^{7}$ Primers like Alice's Visit, and others published around the same time, educated U.S. school children on the growing U.S. empire that followed the Spanish-American War. I loosely label each of my primary texts as "travel writing," but perhaps the most recognizable example of travel writing in the group is Edith Wharton's travel guide In Morocco. In Morocco was initially published in serial form in Scribner's Magazine-one of the "elite" magazines, which set itself against more sensational newspaper venues. While Wharton is a well-known and celebrated American author, her travel writing (and especially In Morocco) has 
received far less scholarly attention than the rest of her oeuvre. This may reflect a tendency among literary scholars to dismiss travel writing as, to quote Alfred Benedixen and Judith Hamera, "unimaginative hackwork" (1). Travel writing attracted both well-known authors like Wharton and those who were lesser known like Bly, Hamm, and Krout. The "travel-guide," one of several packages for writing about travel, became increasingly popular in the U.S. following the Industrial Revolution, which provided easier and faster ways to travel. As Mary Schriber points out, this period ushered in a tremendous amount of travel writing by U.S. women. “Women's travel writing," Schriber explains, "often offers personas who, in the act of freeing themselves physically from geographical constraints, free themselves from less tangible ideological boundaries hemming them in" (8).

Wharton had fewer "boundaries" than women of color or working-class travel writers. In fact, each author in this study traveled with the advantage of racial privilege. But rather than accepting this as par for the course in a white supremacist culture, I instead examine their work as a way to unpack the workings of whiteness and gender within the context of U.S. imperialism. Though a recuperative project that focuses on the experiences and articulations of white women abroad within the context of imperialism may initially appear passé, I argue that it is central to creating a complex and nuanced portrait of U.S. imperialism in all its manifestations. A closer look at turn-of-the-century white women's writing about empire reveals a complex discursive process wherein U.S. women merged concerns over gender, race, and citizenship. As Yoshihara notes, white women "positioned themselves as practitioners, critics, and experts" on discourses of U.S. empire-building (7). Further, these women used the imperial context to create unprecedented opportunities for women in public, professional, and political spheres. 
The differing genres, locales, and experiences of each individual writer shows the variance of white women's participation in U.S. empire building and the ways that it dovetailed (even depend upon) other discourses such as gender equality, race, and citizenship. An analysis of these forgotten texts also reveals the extent to which white women engaged in the intimate aspects of empire-building, thus merging domestic and foreign interests on a global scale. Ultimately, an investigation into the role of white women and U.S. imperialism demonstrates the extent to which women, through discourses of imperialism, were able to gain material power and efficacy in the public sphere, not only in relation to white men, but also colonized subjects, nonwhite U.S. citizens, and new immigrant populations entering the U.S. in record numbers at this time. White women's participation in U.S. imperialism, beyond providing new public visibility and agency, resulted in dramatic changes to constructions of "white American womanhood" (Yoshihara 6). This is not a project that celebrates the individual achievements of the selected authors (though I do believe that in many ways their lives were remarkable). Instead, I see these texts as discursive constructions, created in complex nexuses of knowledge and power, that reveal the multifaceted intersections of gender, race, and U.S. empire at the turn into the twentieth century. Examinations of colonial subjectivity and modes of resistance will always be a necessary project, but there is also value in analyzing the discursive creation of those power structures that colonial subjects resisted.

\section{The Home Terrain: U.S. Women and Reform}

Historians generally consider 1880-1920, the years framing this study, as the Progressive Era in U.S. history. In the 1880s, America was in the midst of its second Industrial Revolution. Advancements in technology, including the mass production of railroads, were making the United States, and the world, seem like a smaller place. Following the economic boom of 1880s, 
came the crash of 1893 . The severe depression of 1893 , caused by the overproduction and precarious financing of railroads, resulted failing banks, businesses, and farms that ceased production. Stock prices declined while unemployment sky-rocketed. Concerns over industrialization, urbanization, immigration, and the rise of monopolistic corporations came into keen focus within the context of wide-spread economic failure. As a result, a wave of social and political reforms swept the U.S. Progressivism was "a complex, sometimes contradictory amalgam of social criticism, popular protest, political restructuring, economic regulation, and social welfare legislation, [that] embodied a vast array of responses to the changes taking place in American society at the turn of the twentieth century" (Dye 1). In short, Progressives wanted to reform the political process to address social ills, such as labor and living conditions in urban centers.

U.S. women played a key role in the Progressive movement. Women were actively involved in the fight for suffrage, though they addressed issues that reached beyond suffrage. Nancy Dye argues that during this period women called into question the separation of private and public spheres. She notes that "Many of women's reform efforts were directed at exploring and documenting the connections between the private world of the household and the political and economic institutions of the larger society" (4). Through political involvement, women hoped to achieve more control over the economic forces that dictated their position in society. Specifically, women hoped to carve out a place for themselves in politics through involvement in “municipal housekeeping," which emphasized "local” issues like the improvement of women and children's labor conditions, clean water and pure food, improved sanitization, and better housing and schools. Ultimately, women saw these areas of the social as places wherein they could attain unprecedented political agency. Clubs and associations became the major means 
through which these women organized, including the prominent racially exclusive General Federation of Women's Clubs. Many white women progressives, such as Margherita Hamm and Mary Krout, continued to promote genteel Victorian notions of femininity while simultaneously embracing New Woman rhetoric and working toward increased political agency. For these women and others, these two issues - femininity and political agency_-were not mutually exclusive.

As a result of white women's continued attachment to racial privilege, they often excluded women of color from various reforms including suffrage. Racially segregated women's movements were a symptom of the social, cultural, and political atmosphere in the U.S. The memory of slavery, the lynchings of the 1880s, the installation of Jim Crow, and the failures of Reconstruction all contributed to a hostile socio-political environment for non-whites in the U.S., including African Americans, Native Americans, and immigrant populations. Progressivism brought into stark relief the "racial tensions and class strife in the new century" that "illuminated not only differences in the daily lives of blacks, Latinos, and Anglos, but also the conflicts generated as each group pursued its own version of civic improvement, community order, and social justice" (Hewitt 27). Rather than embracing non-whites as part of their reform initiatives, white women reformers were more likely to take non-white populations as subjects for reform. In addition to race, class differences contributed to the exclusionary tendencies of white reformers. As Ardis Cameron explains, "Immigrants and minorities were seen as objects to be reformed because of home labor and consumption practices that were considered questionable by white urban women reformers" (57). White progressives widely deployed the rhetoric of "uplift" regards to those they deemed lower on the evolutionary ladder. Ultimately, even with its 
emphasis on civic and social justice, mainstream progressivism upheld white supremacy and the subordination of African Americans and other racial minorities (Rouse 12).

Many African American women developed their own reform initiatives by establishing separate associations and clubs. Charlotte Rich explains that African American women organized separately from white women and centralized "the race question," which "New Negro Woman" was often short-hand for, in their reform goals (Transcending the New Woman 21). Throughout the 1890s, African American women established several associations, including the Bostonbased Women's Era Club and Washington, D.C.-based National League of Colored Women. However, these clubs (and others) were denied recognition from the General Federation of Women's Clubs, thus prompting African American women to create their own National Association of Colored Women in 1896.

Those committed to white supremacy in the U.S. utilized several turn-of-the-century disciplines to support their "racial uplift" initiatives. These disciplines included anthropology, genetics, biology, historiography, and psychology among others. As Matthew Frye Jacobson points out, the field of "evolutionism" was particularly useful as "a model whose central tenets in one form or another had by the late nineteenth century swept across biology, anthropology, some schools of historiography, and the rising sciences of the human mind and intelligence" (139). Proponents of this thinking posited that despite a probable "common origin" of mankind, different races had developed along very different lines-Anglo-Saxons being the most advanced along the evolutionary path, while non-whites occupied lower rungs on the evolutionary ladder. Those in power then deployed scientific racism as a key mechanism in the U.S. government's biopolitical governance of its domestic and overseas territories. 
As the Progressive Era pressed on, not only was immigration to the U.S. growing in record numbers, but the U.S. was becoming a global imperial power. Progressives were split regarding the issue of extraterritorial expansion. Some vehemently opposed U.S. imperialism because they felt that the imperial paradigm (i.e., U.S. political control over foreign peoples) was in direct opposition to U.S. constitutional values. Others, like Hamm, saw imperialism as a solution to the economic problems the country was facing as it recovered from the Panic of 1893. From this perspective, newly acquired territories potentially offered a wealth of natural resources, cheap labor, a market for over-produced goods, and pathways, especially in the Pacific, to a mythologized Chinese market. The discussions regarding the pros and cons of U.S. imperialism took on an urgent significance following the Spanish American War in 1898. After Admiral Dewey defeated the Spanish armada in Manila Bay, the U.S. took possession of Cuba, Puerto Rico, Guam, and the Philippines. Just a few months prior, the U.S. had annexed the island nation of Hawaii. Within a short time, the U.S. had developed an extraterritorial presence, which challenged conceptions of domestic, foreign, citizen, subject, and nation.

\section{Women's Suffrage and U.S. Expansion}

Most historians consider women's reform of this era in a "local" context; however, as Bly's interview with Anthony shows, U.S. women fought to participate in discourses of foreign policy and often considered women's rights, especially suffrage, in relation to the issue of imperial expansion. Many anti-imperialists assumed, incorrectly, that suffragists would necessarily also be anti-imperialist, due to women's supposed repugnance toward violence and war and the anti-democratic aspects of imperial rule. In her study of imperialism and suffrage, Allison Sneider rightly posits that suffragists, a group that itself had many internal fissures, were not of one opinion about U.S. empire-building and its impact on U.S. women. Suffragists were 
split in their support of the Spanish American War; in fact, notable suffragists Julia Ward Howe and Elizabeth Cady Stanton supported a war with Spain. When asked if she favored the war, Stanton responded, "War under many circumstances is a great blessing"” (qtd. in Sneider 93). She expressed regret that "we did not thrash that cruel, brutal nation, with her bull-fights and inquisition, years ago" (qtd. in Sneider 93). Nellie Bly also enthusiastically supported war with Spain as an effort to liberate Cuba; she even proposed an "all women" regiment arguing that "Wars in the future must and will be planned and offered by women"” because "with calm, intelligent, noble women leading the way there would be no such thing as drawn out battles"” (qtd. in Kroeger 290). ${ }^{8}$ On the contrary, some suffragists argued that any resources allocated toward foreign territories would necessarily result in fewer resources for the immediate task (i.e., securing the vote) in the U.S.

Suffragists came from diverse backgrounds, and the suffrage movement was divided along racial and class lines like many other Progressive Era reform groups. White suffragists barred black women's participation in in white women's social clubs and suffrage associations. In her study of U.S. women's movements, Louise Michele Newman explains how white women used religion, science, and politics to assert their role as "the primary definer and beneficiary of women's rights" (Newman 5). Newman explains that white women leveraged "religious conviction (the ideal of Christian benevolence), with science (social evolutionary theories), and political ideology (progressivism)" to maintain racial hierarchies that presumed Anglo-American Protestants were culturally and physiologically superior to all others people (7). Black suffragists, notably Ida B. Wells, mobilized efforts among African American women and created local and national organizations including the National Association of Colored Women $(\mathrm{NACW}) .{ }^{9}$ Even though the NAWSA refused to allow black participation, white and black 
suffragists maintained a dialogue with one another. Though, despite occasional cooperation, most white suffragists remained steadfast in their commitment to white women's rights based upon their sense of supposed racial and moral superiority over black women (Newman 6). Hamm, Bly, Krout, and Wharton each had a varying level of commitment to the suffrage cause, but they were all well-versed in social Darwinism as a way of understanding, promoting, and preserving racial hierarchies at home and abroad. ${ }^{10}$

The U.S. added new territories to the union through annexation, treaty, and incorporation, which provided new opportunities for suffragists to raise their concerns on a national scale. ${ }^{11}$ In the 1870 s and 1880 s, political debates regarding statehood for the Western territories offered an opportunity for discussing women's votes at a national level. The politics of national territorial expansion had to directly confront the problems of Indian citizenship and Mormon polygamy. In 1869, Wyoming's territorial legislator gave women the vote and in 1870 the Utah Territory followed suit. If these territories were in fact made into states, then the government would potentially (and inadvertently) set a national precedent for the woman's vote. Though many suffragists scoffed at the possibility of Indian suffrage before their own and could not reconcile polygamy in Mormon communities, they nonetheless saw these opportunities as ways to pivot the suffrage issue away from states' rights and secure suffrage as central to debates over territorial expansion. As Sneider explains, "Women's enfranchisement in the territories turned statehood debates into unexpected national referenda on the question of woman suffrage and on the nature of national authority over the vote" (58). Suffragists became experts in making the national question of territorial expansion align with the "woman question," thus recognizing how the expansion of "national borders could reconfigure the gendered boundaries of political space" 
(Sneider 86). Suffragists would recall this lesson as the U.S. shifted from contiguous to extraterritorial expansion.

U.S. suffragists, still under the direction of Stanton and Anthony, saw the Spanish American War and its aftermath as an opportunity to raise the suffrage issue on the national level yet again. Sneider notes that suffragists "largely concerned themselves with the strategic question of how U.S. control over new island territories might provide opportunities to get national precedents for women's voting right" (Sneider 86). Though Snider maintains that the "abstract question of the Filipino or Puerto Rican right to self-government" was not a focus of suffragists, it is hard to see how these two issues could have been handled in isolation. Undoubtedly, suffragists were split on their support for the Spanish American War and U.S. imperial ambitions. As noted, some felt as though this was merely a distraction from the suffragist cause, while others felt that it opened further national discussion for women's votes. At any rate, suffragists remained almost myopically focused on how the situation of overseas territories could enhance their chances of gaining the vote for U.S. (white) women through a constitutional amendment. The fact remained that each new territorial constitution was a chance to enfranchise women, or at least not disenfranchise women. Anthony urged both anti- and prowar suffragists to direct their energies to the consequences of the war rather than the merits or justness of U.S. military engagement with Spain. Specifically, Anthony wanted to focus on the content of each new territorial constitution in an effort to ensure that word "male" be omitted from such documents. Stanton was less concerned with the anti-democratic components of imperialism, and, instead, focused her energy on "a critique of patriarchy" (Sneider 91). Through this process, Sneider maintains, Anthony and the NAWSA lent their "tacit approval to the U.S. imperial project" (91). 
An illustrative example of the NAWSA's strategy is the 1899 Hawaiian Appeal, a petition to Congress that demanded suffrage for all women — both U.S. and native - in the territory of Hawaii. In July of 1898, the U.S. annexed Hawaii through a congressional joint resolution (despite tremendous protest among many native Hawaiians). The exact terms of U.S. control were unclear, though the plan was for Hawaii to become a federal territory and eventually a state. Therefore, Congress planned to create a Hawaiian territorial constitution (Sneider 90).

Suffragists saw an opportunity in the new territorial constitution of Hawaii, and focused their efforts on the Hawaiian Appeal. The Appeal requested that, "In the qualifications for voters in the proposed constitution for the new Territory of Hawaii, the word 'male' be omitted" (20). It continues, "The declared intention of the United States in annexing the Hawaiian Islands is to give them the benefits of the most advanced civilization, and it is a truism that the progress of civilization in every country in measured by the approach of women toward the ideal of equal rights with men" (20). The Appeal then meticulously listed suffrage achievements and gains (including those U.S. states and territories that did allow women's suffrage, like Wyoming and Utah, along with international examples such as Australia's passage of women's suffrage). The Appeal did not limit the vote for white women who were U.S. citizens, but it requested the vote for native women by arguing that native women were especially victimized by savage Hawaiian men and therefore needed the voting rights. Specifically, the Appeal argued that Hawaiians were in the process of moving from the "physical plane" of existence, wherein native women relied upon themselves and where "her failure or success depends wholly on her own strength," to an “intellectual place" of existence (20). The "intellectual plain" was governed by law-laws that would, according to the Appeal, enhance the lives of native "women emerging from barbarism 
[and] the ball and chain of a sex disqualification" (20). The rhetoric of the Appeal depended upon the discourses of civilization, universal womanhood, and male savagery — all underpinned by the assertion that their Hawaiian "sisters" were less civilized and racially marked. The Appeal, Sneider argues, "grafted the Reconstruction era focus on federal constitution writing to the new realities of U.S. imperialism" (92). Importantly, the Appeal merged two "vocabularies" all within the context of women's suffrage — one of citizenship and rights and the other of race and civilization.

Beyond Stanton and Anthony, there were thousands of suffragists that added to the growing commentary regarding suffrage and U.S. imperialism. Many of these commentators were in the newspaper business. Hamm, Bly, and Krout were, for all intents and purposes, suffragists, as their newspaper journalism indicates. Bly, in her conclusion to her interview with Stanton, offered a call to action: "Let us all help to promote the cause of woman suffrage" (137). Throughout her professional career, Bly advocated for the vote and lobbied for the rights of women laborers. Though her newspaper writing, Bly posed controversial questions such as: “Should Women Propose?" She answered this question in the affirmative, asking "What gives a man the sole right to ask the one he loves to wed him?” (123). Bly's feminist sensibility undoubtedly informed her travel writing. In Mexico, she criticized the subjection of Mexican women to their husbands and the overall patriarchal nature of Mexican society and politics.

Krout and Hamm, perhaps more subdued than stunt-reporter Nellie Bly, took a more conservative approach to suffrage but still promoted it in their newspaper writing. Each was well-known within suffrage circles. Hamm's name even appeared alongside Anthony's and Stanton's in Frank G. Carpenter's 1895 "If Women Were Members of Congress" in the Boston Daily Globe. Hamm edited a column titled "Among the Newspaper Women," wherein she 
featured other progressive women journalists for their contributions to women's rights. In an article titled "Some Women Editors," which appeared in an 1886 edition of Peterson's Magazine, Hamm acknowledges a growing field of women's journalism within the context of international engagement: "The extension of journalistic fields, and the ever-growing interest taken by the people of one country in the life of other nations, has made the foreign editor and correspondent a general feature of daily journalism. In this new department women are already doing excellent work" (609). The exemplary female journalist that Hamm features is none other than Mary Krout, whom Hamm praises for her dual journalistic commitment to foreign politics and women's rights.

Both Hamm and Krout edited their own columns that primarily focused on women's rights for leading U.S. newspapers including The New York World and The Chicago Inter Ocean, respectively. Like other suffragists, they took an active interest in the United States' imperial territories. Unlike most other suffragists, each traveled extensively throughout the newly acquired U.S. territories. They were, for lack of a better phrase, "the boots on the ground," providing the raw data used for shaping arguments for and against annexation, expansion, and suffrage within U.S. territories and spheres of influence. Their presence abroad, and their subsequent publications and lectures, complicate Sneider's assertion that "suffragists did not understand...the fine distinctions between Hawaii and the Philippines, or the distinctions being made between Cuba and Hawaii, or between Cuba and any of the other island territories in the former Spanish empire" (101). Sneider concludes that it was "difficult for suffragists to think about expansion in specific and individual terms" (101). While this was probably true in many cases, the work of Hamm and Krout suggests that some suffragists did manage to negotiate the politics and conditions specific to varying locales of U.S. imperialism. Overall, both Hamm and 
Krout supported U.S. imperial invention into the Pacific, providing rationales that were steeped in the rhetoric of U.S. exceptionalism and white supremacy.

Krout, Bly, and Hamm were all committed to the cause of U.S. women's suffrage and added to public discourses of not only women's rights, but also women's rights in conjunction with U.S. empire-building. Edith Wharton, on the other hand, remained somewhat ambivalent toward both U.S. expansion and suffrage. Elizabeth Ammons notes that Wharton's attitude toward equality for women changed throughout her lifetime. Growing up in the affluent class of New York City's elite, Wharton spent the 1890s and early 1900s developing a theory of women's rights that fused "sociological, economic, psychological, and anthropological perspectives" (Argument ix). By the 1920s, Wharton grew conservative in her gender politics. She criticized the figure of the New Woman and remained "aloof" regarding suffrage (Ammons, Argument 2). Wharton supported women's education and professionalism, but largely dismissed the work of suffragists. Wharton's primary gender critiques were related to the institution of marriage. Her fiction in the 1900s reveals her position that "until fairy-tale notions of romance and marriage are relinquished...equality between the sexes, and thus the full emancipation of women, rich or poor, new or old fashioned, will not come to pass" (Ammons, Argument 57). Wharton might have remained ambivalent toward the vote, but she was a self-proclaimed "rabid imperialist" (qtd. in Wegener 783). ${ }^{12}$ As the work of Frederick Wegener has shown, Wharton surrounded herself with well-known expansionists, including her close friend Teddy Roosevelt. Based upon her papers and letters, Wharton appeared to support U.S. imperialism, along with French and British imperialism, in the early years of the twentieth century. In some ways, her attitudes toward empire were informed by and contributed to Wharton's racialization 
of African American and immigrant populations, along with her commitment to evolutionary Darwinism, which is well documented by Wharton scholars.

\section{U.S. Women and Occasions for Travel}

In June of 1899, Hamm made an acute observation in the pages of Frank Leslie's Popular Monthly. "As the world grows smaller," she wrote, "the number of women travelers grows great" (13). Travel, and its technologies, she argued, "opened new opportunities for ambitious women" ("Women as Travelers" 13). This statement was more controversial than it first appears; the underlying assumption was that women's traditional roles in U.S. were changing as rapidly as the technology that allowed for faster and easier travel; the steamship and the rail car were among the most celebrated. Travel, Hamm and others maintained, opened new professional opportunities to women and offered more occasions for women's participation within public spheres. The image of the traveling woman stood in stark contrast to earlier images that dictated ideal femininity, including the antebellum "cult of domesticity," which was encapsulated in the image of the True Woman. Kaplan explains that the "cult of domesticity" was an extension of the ideology of separate spheres, which posited that a woman's "hallowed place is within the home" (Anarchy 24). ${ }^{13}$ By the 1890s, a new articulation of female identity emerged in Britain and the United States: the New Woman. Usually, the story of American women's shift from True Woman to New Woman goes something like this: the dual forces of industrialization and urbanization created new public spaces for women (Ammons, Conflicting Stories 7). Absent from this description is the force of imperialism and expansion abroad as potential contributing factors to the development of alternative gender configurations.

The phrase "New Woman," originating from Henry James's image of the "rebellious" American woman, was used "to describe a monolithic figure that encompassed all modern 
Bebell 38

women at the turn into the twentieth century" (Ammons, Conflicting Stories 7). The New

Woman was stereotypically white and middle class, was born between the years 1850-1890, and married later than their predecessors (if at all). If they had children, they had fewer than earlier generations. Women had new options other than wife and mother due to increased educational and professional opportunities. In addition to the New Woman, the Bachelor Girl emerged as yet another alternative to the "angel of the house." Similar to but distinct from the New Woman, the Bachelor Girl had fewer financial resources than the New Woman, lived alone, and pursued a demanding career. Descriptions of the Bachelor Girl “focused on unmarried women’s living arrangements, behavior, and personal appearance" (Fahs 139). Krout, a self-described Bachelor Girl, explained that "the bachelor woman [is] a product of modern opportunity and civilization. There are thousands of such women in the United States to-day...They crowd the school-room, the colleges, the professions; they make a business of art and literature" (qtd. in Fahs 137). ${ }^{14}$ Krout, Bly, Hamm, and Wharton all epitomized several aspects of "new" womanhood. None had children, and though Bly, Hamm, and Wharton married they each also divorced. With the exception of Bly, each had some level of formal education beyond high school and all maintained successful professional careers throughout their lifetimes.

The shift from True to New Woman was not a smooth or straightforward sociohistorical process that impacted all American women in the same way, and we should be careful not to present this shift as an all-encompassing linear narrative. For instance, white women and women of color experienced this shift in markedly different ways due to the racist and sexist underpinning of U.S. culture. Class, too, was a factor in how femininity was understood and performed. Many working class women, both white and black, worked in the public out of necessity long before this activity was sanctioned or made fashionable with the advent of the 
"New Woman.” Additionally, the New Woman did not come of age in cultural vacuum. As Martha H. Patterson notes, the New Woman emerged within a "wide range of social, economic, aesthetic, and political discourses" (3). Proponents of women's rights needed to negotiate the "increasing impact of evolutionary theory, incorporation, consumer culture...Jim Crow, xenophobic legislation, and imperialist missions at home and abroad" (Patterson 3). The "imperialist missions at home and abroad" is the thematic focus of my examination of the turnof-century gender and travel, but it is inseparable from those other discourses that created the context of U.S. women's travel and the general parameters of U.S. culture. While the trajectory from True to New woman is overdetermined and mostly limited to the experiences of white middle-class women, it does provide an overview regarding the general shift in attitude toward women in U.S. culture.

The New Woman, though celebrated today as a feminist, was not always (or even often) a welcome figure in turn-of-the-century America. Some argued that the New Woman, with her increased mobility and independence, signified an irrecoverable loss of the principles of traditional American society. A poem appearing in Harper's in 1898 by Charles Henry Webb titled "The New Woman" lamented the loss of the True Woman, imploring American women to reverse the course of their journey: "Does the New Woman, then / In her singular babies,/ Find nothing in men — / Next to nothing in babies?/ See, sister, I kneel / Though I don't often meddle,/ And I pray cease the wheel/ Oh woman, back-pedal" (264). Webb was not alone in his assertion that the New Woman threatened the very continuation of the nation in her supposed rejection of the roles of wife and mother. What is more, Webb directly links the New Woman with movement and travel. Specifically, he asks women to "cease the wheel" and "back-pedal," alluding to movement, mobility, and freedom. Webb refers to what Sidonie Smith calls 
"machines of motion," the ship, rail car, and bicycle, which made women's travel possible at the turn into the twentieth century (xi). Machines of motion were the ultimate symbol of American modernity during the Progressive Era, and travel was most often considered a man's activity (Smith x). As Sidonie Smith notes, "Even though travel has generally been associated with men and masculine prerogatives...women have always been and continue to be on the move" (Smith x). This sense of "women on the move" was exactly what Webb criticized. It was enough that women were rejecting their national duty as wives and mother, but now they were also physically mobile, an outward manifestation of the upward mobility of U.S. women in educational and professional arenas. Again, race and class dictated how specific women negotiated machines of motion. For white women, access to machines or motion and, by extension travel abroad, often signaled their racial privilege.

Most of what we know about U.S. women's travel between the years of 1880-1920 is based upon their own written accounts. As Hamm articulates in "Women as Travelers," travel opened professional opportunities for women, including the role of travel writer. Hamm notes that "travel and literature present a fine industrial field for the educated women. Books of travel are always in demand" (13). Hamm was right. The U.S. market was flooded with accounts of travel and the sheer number of women traveling prompted one scholar to describe this phenomenon as "female exodus" of epic proportions (Schriber 13). At this time, women travelled to many of the same places as men, including China, North Africa, Arabia, Central and South America, the South Pacific, the Caribbean and beyond. Women traveled abroad under many different circumstances. Following the Spanish American War, U.S. women traveled to newly acquired territories as the wives of U.S. political functionaries, as teachers, as journalists, and as missionaries. Schriber notes that several different "occasions" prompted U.S. women to 
travel and then record their experiences, including autobiographical, political, and cultural occasions (171). Political and cultural occasions are of particular interest to this study of women's travel writing. "Travel-as-politics," Schriber explains, prompted women to write accounts of travel that interrogated U.S. domestic and foreign politics as they affected U.S. women. In this way, women's travel accounts "write the nation" in their own image (Schriber 134). Women journalists, like Hamm, Krout, and Bly merged travel writing with politics, as both journalism and travel writing provided a space to address politics (such as women's rights discourses) directly. Women used journalism coupled with travel writing to "make themselves heard on national and international issues, including concepts of gender and rules of decency the impinged on their daily lives at home and abroad" (Schriber 165). From another perspective, women journalists and travel writers practiced "travel-as-culture," wherein the experience of travel, and subsequent writings about said travel, operated as a way to enhance the author's cultural capital and their place within the broader genres of journalism and travel literature. Rather than seeing travel-as-politics and travel-as-culture as independent categories, I submit that the two motives overlap in the works considered here, thus suggesting that the desire for political agency and cultural capital constituted were never mutually exclusive.

Mary Louise Pratt's foundational work on travel writing suggests that "journalism and narrative travel account" were influential in creating a "planetary consciousness" for EuroAmerican reading publics $(26,15)$. Journalism and narrative accounts of travel are just two of several popular forms of writing-about-travel. The genre of "travel writing" is, to use to Bendixen and Hamera's word, "murky" (2). Travel themed writing could fall into any of the following narrative forms, or mix several of these forms, including: first-person journals, 
pseudo-fictional accounts, meditations, personal essays, romances, poems, periodicals, and anthropological or ethnographic treatises, to list several of the most popular forms (Smith 26-27).

As already mentioned, this study explores several travel-themed genres, including geography primers, newspaper writing, and the more traditional travel guide. The authors included share three elements: 1) the author of the text literally traveled to the location explored in the writing, 2) the locations visited were, I argue, important to notions of U.S. empirebuilding, and 3) these works were published in either newspapers or other publishing institutions during the authors' lifetimes. The travel-themed texts I explore were all initially published in periodical form. Bly, Krout, and Hamm published their work in widely circulated newspapers such as the New York World, the New York Journal, and the Chicago Inter Ocean among other venues before collecting their dispatches into full book-length volumes. Wharton's In Morocco was first published in Scribner's literary magazine in serial before being collected into a full length travel guide.

In the following chapter, I examine Hamm's writing that followed the Spanish American War including Manila and the Philippines and America' New Possessions and Spheres of Influence. Hamm, an erudite social Darwinist, celebrates the U.S. as growing nation finally realizing its full potential as a global imperial power. I then shift to another area in the Pacific to study Krout's writing about Hawaii. The chapter focuses primarily on her children's geography primer Alice's Visit to the Hawaiian Islands and her desire to promote a pro-empire/pro-woman education for U.S. schoolchildren. I then move away from the Pacific to consider Bly's Six Months in Mexico. Bly emerges as a more contradictory figure whose work represents the ways in which the United States exerted control over its spheres of influence. Like Krout, Bly's work contains a powerful expression of a desire for women's rights in the U.S. The final chapter 
Bebell 43

moves from Mexico to Morocco. I consider Wharton's In Morocco as an example of the transnational flow of U.S. imperialism and as an expression of American Orientalism in action. 
Bebell 44

\section{Chapter Two}

The "Natural" Growth of the Republic: Race, Gender, Sex, and Science in the Writing of Margherita Arlina Hamm

\section{Introduction: The "Treasure Island of the Pacific"1}

On May 29 1902, in the midst of the Philippine-American War, Clemencia Lopez addressed the New England Women's Suffrage Association at their annual meeting. Lopez, a Filipina from a landed gentry family of Batangas province, wished to tell the Association "something of the condition of the women in the Philippine Islands" (184). At this time, the brutal Philippine-American War was in its second year. The U.S. was well into its "scorched earth" campaign to "pacify" the Philippines under the umbrella of what President McKinley famously called "benevolent assimilation." In her own words, Lopez wished to promote "a different and more favorable opinion of the Filipinos than the conception which the generality of American people have formed, believing us to be savages without education or morals" (184). Lopez argued that Filipinas and U.S. women were more alike than different. "I believe," Lopez explained, "that we are both striving for the same object-you for the right to take part in national life; we for the right to have a national life to take part in" (184). As may be obvious, Lopez's assertion for gender equality rings of anti-imperial sentiment. U.S. women, according to Lopez, had a national life, whereas Filipina women lacked a sovereign nation. Lopez revealed that Filipina women "differ very little from the general condition" of women in the U.S. (184). She explained that in the Philippines gender equality was "not introduced from Europe, but was innate, and the natural expression of the love and respect which a man ought to feel toward his mother, his wife, and his daughters" (184). After establishing comradery between U.S. women and Filipinas, and conceding that "American women have greater liberty than we," Lopez asked 
the Association to join in the fight for Filipino independence. Lopez left her audience with an image of the "horrors and cruelties" of war and its impact on women in the Philippines: "I do not believe you can understand or imagine the miserable conditions of the women of my country, or how real is their suffering. Thousands have been widowed, orphaned, left alone homeless...It is, then, not a surprising fact that diseases born of hunger are increasing, and that to-day immorality prevails in the Philippines to an extent never before known” (185).

I begin with Lopez's address because it sheds light on the understudied intersection between U.S. women's suffrage and U.S. imperialism following the Spanish American War. Lopez identifies U.S. suffragists as potential allies in the fight against U.S. imperialism. It initially seems reasonable that Lopez thought she'd find allies for Filipino independence among the New England Women's Suffrage Association. Lopez assumed that all women had an innate repugnance toward war and identified with those whose rights were confiscated by an overarching socio-political structure. Yet, as I noted in the introduction, U.S. suffragists were split on the twin issues of war and imperialism. Certainly, there was an active anti-war/anti-imperial cohort among suffragists for whom Lopez's appeals would have resonated. At the same time, a proportion of U.S. suffragists not only supported war with Spain, but supported any and all territorial expansion resulting from the war. One such supporter of U.S. expansion was journalist and suffragist Margherita Arlina Hamm. There's no record that Hamm was present for Lopez's address, but as an avid reader of and contributor to The Woman's Journal, it is almost certain that she read the address. Hamm considered herself an expert about both "women's issues" and the Philippines as evidenced by her newspaper writing and books on the subjects. And while Lopez surely had sympathetic supporters for Filipino independence within the suffrage community, Hamm was likely not one of them. 
Indeed Hamm's name is absent from most histories of U.S. journalism, suffrage, and imperialism. Yet she played a key role in all three arenas during the late nineteenth and early twentieth centuries. Hamm began her professional career as a journalist. She wrote for highprofile newspapers including the New York Journal and the Boston Globe. Early on, her columns focused on “women's issues.” Her first newspaper column for the New York Journal, “Among the Women," highlighted the work of fellow newspaper women. She offered commentary on the attributes and accomplishments of her contemporaries. She was also an active participant in the National American Woman Suffrage Association; her name even appeared alongside Susan B. Anthony and Elizabeth Cady Stanton as a potential Congresswoman in the aspirant article "If Women Were Members of Congress" published in the Boston Globe in $1895 .^{3}$ Columns like Hamm's, Alice Fahs asserts, created a "public community of independent” and professional women (1). When Hamm was not writing about women's equality, she focused on foreign politics. Following her marriage, Hamm accompanied her husband to China, Japan, and Korea. ${ }^{4}$ As a self-titled "foreign correspondent," Hamm reported on the Sino-Japanese War of 1894. Once the Spanish American War began, Hamm wrote stories from Cuba, Puerto Rico, Hawaii, and the Philippines. While debates over war and U.S. overseas expansion played out in the press, Hamm's position was clear; she unapologetically favored U.S. territorial expansion into the Pacific and beyond. Before her untimely death at age thirty-six, Hamm predicted that the spread of U.S. empire across the globe would be the defining feature of the twentieth century.

This chapter explores a handful of Hamm's newspaper writings in conjunction with two of her book-length works: Manila and the Philippines (1898) and America's New Possessions and Spheres of Influence (1899). Both texts are compilations of Hamm's many newspaper articles. The results are ephemeral and somewhat quirky volumes that contain various types of 
information, which range from geographical features of select locales, commercial opportunities and natural resources, and lengthy and descriptive accounts of native populations. As the titles suggest, Manila and the Philippines is limited to the archipelago, while America's Possessions contains a more comprehensive account and endorsement of America's growing territories and “spheres of influence." This is far from a holistic account of Hamm's oeuvre. Rather, my focus is on Hamm's relationship to U.S. expansion and empire as it relates to her feminist politics. As Gail Bederman notes, Progressive era "feminism was inextricably rooted in the white supremacist" discourse of "civilization" (123). "Civilization," Bederman continues, "drew on ideologies of race and gender, but people with different political agendas could deploy the discourse in a variety of ways" (121). Anti-feminists could use "civilization" to demonstrate, usually through the language of social Darwinism, that women were less civilized than menless developed in mind and body (Bederman 121). At the same time, feminists simultaneously deployed the discourse of "civilization" in the interest of arguing just the opposite- - that advanced societies acknowledged women as full citizens. "Civilization" always signaled race (whiteness) as well. For Hamm in particular, her attachment to social Darwinism and racial science likely contributed to her unwillingness to feel solidarity with non-white subjects of U.S. imperialism and enhanced her argument that empire-building was the natural, biological extension of a civilized nation. Hamm uses an organicist theory of the nation and deploys the language of scientific racism to advance the cause of U.S. empire, but, in doing so, she favors white solidarity over feminist solidarity, thereby suggesting that white women and white men "share a racial bond that made them partners in advancing civilization" (Bederman 124). 
Bebell 48

By the mid-1890s, the U.S. public was paying close attention to the Cuban rebellion against Spanish colonial rule. Cuba Libre was receiving primarily positive coverage in the press and gaining the support of many Americans, including well-known suffragists like Susan B. Anthony and well-known women journalists like Nellie Bly. Initially, the U.S., under the guidance of President McKinley, remained neutral in the conflict. However, after tremendous pressure from the public and fellow politicians, along with the sinking of the U.S. Maine, McKinley signed a resolution for war on April 15, 1898. With this, the U.S. officially engaged in a war with Spain. Less than a month later, the U.S. defeated the Spanish armada in Manila Bay. After the Spanish defeat, the U.S. negotiated the purchase of the Philippines, Guam, and Puerto Rico. In doing so, the U.S. positioned itself as a "global power" and gained valuable strategic presence and influence in both the Pacific and the Caribbean. Through what John Hay deemed a “splendid little war," the U.S. asserted itself as a major player in extraterritorial empire building. ${ }^{5}$

Hamm was on the frontlines of U.S. empire-making, and she wrote extensively in support of imperialism abroad. Her gender politics, while apparent in her newspaper writing, remain almost absent in both Manila and the Philippines and America's New Possessions. In Hamm's descriptions of U.S. territories and spheres of influence, white women appear only in the margins. However, when they do appear it is as consumers of U.S. imperialism. U.S. womenwhite women in particular - may have been consumers of imperial goods, such as Hawaiian pineapples, but they were also producers of American Orientalism through their fascination with and consumption of the region dubiously labeled "The East." In her study of American Orientalism, Mari Yoshihara notes that even though U.S. white women did not travel to newly acquired territories en masse, they did participate in "informal empire" at home (7). Yoshihara identifies ways that U.S. women consumed empire through the literal consumption of products 
imported from the East, but also notes that ways that U.S. white women were producers of empire though their roles as writers, artists, critics, and experts. Hamm situated herself as “expert” and produced knowledge on locations key to U.S. empire-building.

Texts like Manila and the Philippines and America's Possessions added to discourses of U.S. imperialism and performed the cultural work of making far-off locations, like the Pacific, more tangible and familiar to American readers. Geographical locations are not natural givens. John Eperjesi explains that a label such as "American Pacific" does not "simply take hold of an already given region. Rather, the imperialist imaginary produces the region that it takes as its geographical foundation" (4). Further, Eperjesi argues that "the 'American Pacific' is a geographically specific form of American Orientalism” (14). Rather than a foundational geography, the American Pacific is a myth that legitimated U.S. imperial aggression. Hamm's participation in the production of the imperial imaginary raises several questions about how the discourses of gender and race intersect within the discourse of empire-building. Hamm, a middle-class and white, traveled under the umbrella of racial and national privilege, while facing certain limitations due to her gender. Hamm's commitment to gender politics, U.S. imperialism, and white racial privilege suggest the complex intersections that constitute Hamm's professional identity.

I join other scholars in examining the mechanisms of U.S. imperialism in the Philippines at the turn of the twentieth century. After centuries of colonial rule, Filipino revolutionaries desired national independence and rejected U.S. plans to colonize the islands. Led by Emilio Aguinaldo, and dubbed "insurgents" by the U.S. press, Filipino nationalists engaged in a brutal war with the American military that lasted until 1912. Much of the violence and brutality of the Philippine-American war was effaced by the dominant narrative of benevolent assimilation, 
which became the United States' "official” approach to the Philippines. In short, the rhetoric of benevolent assimilation promoted the belief that the primary objective of the colonizer was, to quote President McKinley, "to win the confidence, respect, and affection" of the colonized (qtd. in Rafael 185). ${ }^{6}$ Vicente Rafael explains that in reality the "allegory of benevolent assimilation," which he calls "white love," was "predicated on the simultaneous deployment and disavowal of violence” (186). "The measured use of force," Rafael asserts, "was deemed consistent with the tutelary aims of colonization: that of making the native inhabitants desire what colonial authorities desired for them" (186). In the case of the Philippines, the alleged aim was to “institute the 'democratic' aspirations, sentiments, and ideals"” of the United States (Rafael 186). To accomplish this aim, the U.S. instituted disciplinary tactics and constant surveillance at both the practical and ideological level. Hamm's work on the Philippines certainly effaces the brutality of war in favor of a narrative of benevolent assimilation. Her choice to "dedicate" Manila and the Philippines (finished in 1898) to Emilio Aguinaldo as a "living hero" speaks volumes. One year later, when she completed America's Possessions and while the U.S. fought a war against Filipinos, Hamm's attitude toward Aguinaldo shifted abruptly. Instead of a "living hero," who assisted the U.S. in the war with Spain, Hamm writes that Aguinaldo is "some sort of half breed" who has continued to engage the U.S. army in "mere guerilla fighting" (126).

As studies of U.S. imperialism become more commonplace, many scholars have considered the role of the U.S. in the Spanish American War and subsequent colonization of the Philippines. For instance, Kristin Hoganson provides an alternate historiography of the SpanishAmerican war that places gender as a central force in the U.S. decision to go to war with Spain. The war, Hoganson argues, was a response to a crisis in white male masculinity brought about by a closing of the frontier and the social advancement of women and African Americans, which 
provided a significant psychosocial motive for both a U.S. war with Spain and the subsequent war in the Philippines. Hoganson contends that "gender served as a cultural motive that easily lent itself to economic, strategic, and other justifications for war" (Fighting 9). She continues, “Gender served as a coalition-building political method, one that helped jingoes forge their disparate arguments for war into a simpler, more visceral rationale that had a broad appeal. As both motive and method, gender helped men from different regions, parties, and walks of life come together to form a powerful political movement" (Hoganson Fighting 9). U.S. participation in both the Spanish American and Philippine American wars worked to consolidate and legitimate white masculinity. Ironically, the war with Spain also offered a public space for women's participation in politics_-perhaps an unintended consequence.

This chapter continues with an examination of Hamm's imperialist politics, which she articulates through the language of evolutionary biology, thus arguing that empire-building is the natural, biological extension of the nation. At first glance, Hamm seems to appropriate and reproduce the masculine paradigm of empire-building. Yet her involvement within the suffrage community shows alternative ways that U.S. women merged the discourses of imperialism and women's rights. Hamm promotes scientific racism, which blends discourses of gender, race, and imperialism. I trace the contradictions inherent in Hamm's discussions of foreign others, and consider the extent to which discourses of eugenics and women's equality remained logically incompatible, despite the frequent use of such discourses by members of women's rights communities. Specifically, Hamm depends upon discourses of eugenics and social Darwinism as scientific truth in order to demonstrate Filipinos' innate inability for self-government. At the same time, Hamm herself is the victim of what Foucault calls the "clinical gaze" by members of the phrenological community as shown in an article published on Hamm's physical 
characteristics and mental attributes. While the article is favorable toward Hamm, it still demonstrates the extent to which the (mostly white male) scientific establishment applied discourses of social Darwinism, phrenology, and eugenics to white women often regarding women's aptitude for full political and professional autonomy in the U.S.

\section{Nation as Organism and Hamm's Imperialist Politics}

America's New Possessions and Spheres of Influence (1899) contains Hamm's most complete endorsement of American empire-building. Hamm completed the volume in 1899 following her other book-length works about foreign politics, which include Manila and the Philippines, Porto Rico and the West Indies, and Dewey the Defender. ${ }^{7}$ The "object" of America's New Possessions, Hamm explains, "is to present in condensed form the more interesting facts respecting the growth of the Republic beyond the boundaries of the United States proper" (8). The volume is a sort of compilation of empire; its chapters are organized by location, beginning with the U.S. acquisition of Alaska, moving through Cuba, Hawaii, Puerto Rico, and the Philippines. Along with actual territorial acquisitions, Hamm considers the U.S. “spheres of influence,” including Mexico, Japan, China, and Jamaica. ${ }^{8}$

American's New Possessions is a celebration of U.S. imperialism wherein Hamm argues that the spread of U.S. empire is merely the natural growth of the nation. Initially, it may appear that Hamm is merely recycling pro-imperialist arguments that relied on the logic of manifest destiny, and this is partly true. However, what really stands out in Hamm's rendering of national growth is her assertion that the nation is itself a living, breathing organism that continues to grow or faces an inevitable death. As Benedict Anderson notes in his foundational work on the origins of Western nationalisms, the organic theory of the state is a common aspect of the logics of national belonging. He contends that the nation is often understood as "a sociological organism 
moving calendrically through homogenous, empty time, which is also conceived as a solid community moving steadily down (or up) through history" (26). This shared understanding among members of nation leads to both an inclusive and exclusive notion of national community - those members of the populations who are within the pale of the nation and those who are out (often based upon racial or ethnic difference).

The metaphor of the nation as body speaks to the perceived disembodiment of the white American male, which recalls the overt gender politics of the Spanish American War and subsequent territorial acquisitions. Amy Kaplan notes that often "nationhood and manhood have long been intimately related in the representation of the dynamic of territorial expansion" (Anarchy 95). Representations of U.S. territorial expansion utilized the metaphor of the masculine body because, as Kaplan argues, American masculinity appeared to be under threat in the final decade of the nineteenth century. By the 1890s, overseas expansion provided an anecdote to this loss of masculine purpose. In 1893, Frederick Jackson Turner announced the closing of the Western frontier, which suggested the abrupt cease in contiguous expansion. The "winning of the West," and the bloody conflicts with Native Americans, provided for decades a stage for the performance of American masculinity and power. Moreover, the end of the official system of slavery following the Civil War posed a perceived threat to white male authority. With an influx of immigration, along with strides made toward women's equality, the authority and masculinity of white males never seemed so tenuous. As Kaplan notes, "In the period of the New Woman, the New Negro, and the New South, the New White American Man was invented as a tradition... as nothing new at all but a father figure from an enduring and recoverable past" (98). As a response to this perceived loss, empire abroad was seen as a way to preserve the dominance of the American man; empire offered a new stage for the performance of white masculinity via 
fantasies of imperial control (Kaplan 96). At the same time, however, a "fear of anarchy" loomed large beneath the fantasy of empire (Kaplan 12). The dual assertion of the embodied nation and the necessity of "redefining national power as disembodied" (i.e. separate from contiguous expansion) coexisted as an uncomfortable irony.

The subtext of the biological metaphor of the nation as a response to the perceived loss of masculinity suggests men were actors in empire, while women were mostly "spectators enjoying the pleasures of imperialism" (Kaplan 95). Women certainly were "spectators" of empire, but how does the biological metaphor of nation shift when articulated by a woman? In most ways, Hamm reproduces the nation as body in her explanation of U.S. expansion. Yet Hamm's very presence on the imperial scene (both physically through travel and through her extensive writing) challenges imperial embodiment as a solely masculine project.

In Hamm's biological metaphor she reproduces masculine nation building paradigm through the language of the body, perhaps unintentionally supporting the very masculine ideology that she rejects as a suffragist. Hamm begins the story of imperial expansion by asserting that empire-building represents the "invincible laws of national growth" (America's Possessions). These "invincible laws," Hamm argues, "includes territorial and commercial expansion" abroad (America's Possessions 7). Hamm contends that the U.S. nation literally feeds itself by attaining new territories. In the first chapter of America's New Possessions, Hamm discusses the purchase of Alaska and the Aleutians from Russia. Hamm explains that following these acquisitions there was a brief pause in national growth: "Here for a moment the nation paused, like an animal which has eaten a substantial meal and rests when it is over" (America's Possessions 8). With its metaphoric stomach full, America witnessed the "development and organization of industries and resources such as had never been known before" (America's 
Possessions 7). To continue growing, America needed to continue its extraterritorial expansion. Even the Cuban Revolution, Hamm argues, is more likely the manifestation of America's growth than "an endeavor to secure freedom or to change onerous political conditions" of Spanish rule. Rather, "the entire Cuban movement" was more likely the result of "the law of national growth in the new world" (America's Possessions 8).

Positioning the state as an organism that needs continuous territorial growth to survive undercuts the complicated geopolitical histories of places like Cuba or the Philippines. It effaces the details and violence of U.S. conquest and occupation in favor of a foregone conclusion of eventual (natural) territorial growth. Furthermore, this rendering de-legitimates anti-imperialist arguments as unnatural violations of biological (i.e., natural) law. Even though Hamm deployed this logic of nation building, she still had to address anti-imperialists in a political volume like America's Possessions. She emphasizes the logic of the organic state, noting that she "has but little patience with the doctrines of what is termed anti-expansion and anti-imperialism. The stronger the tree the larger it is bound to grow" (America's Possessions 11). According to Hamm, U.S. expansion will help solidify national identity moving into the twentieth century. "The process of growth," she explains, "merged the New Yorker, the Yankee, the Virginian, the Texan, and the Californian into the American" (America's Possessions 12). What Hamm does not say, because it was an unquestioned assumption of this assertion, is that "the American" she refers to is white. The consolidation of "the American" via national territorial growth promotes imperialism as the key to white national unity. 
Bebell 56

\section{Suffragist (and) Imperialist:}

There is little doubt that Hamm was both an ardent imperialist and suffragist. However, drawing conclusions about a relationship between the two is challenging. Neither imperialists nor suffragists were cohesive groups that shared all of the same goals and ideals. For instance, some suffragists were staunchly anti-imperialist, while others supported certain overseas agendas while rejecting others. This section explores the intersection of discourses of U.S. women's rights and pro-imperialism (or lack thereof) within Hamm's book-length political writing including Manila and the Philippines (1898) and America's New Possessions and Spheres of Influence (1899). In Fahs's study of turn-of-the-century women journalists, she explains that women journalists and the fight for suffrage are usually discussed separately by historians, if at all. She notes that "newspaper women who covered suffrage practiced a form of politics little addressed" (275). This absence is matched by a lack of critical investigation of newspaper women's role in U.S. imperialism. Since there are deficiencies in both areas, even less is known regarding how these two discourses—-suffrage and imperialism—intersect in the writing of female journalists at the turn-into-the twentieth century.

Hamm self-identified as a suffragist. She was passionate not only about the vote, but also about women's advancement in professional careers - most especially in journalism. When she was not working as a foreign correspondent, Hamm focused her journalism on issues pertinent to the advancement of white women in the United States. Hamm was the editor of the Woman's Department at The Daily Mail and the Suffrage Department at the popular Pearson's Magazine. Moreover, Hamm created the short-lived Woman's Suffrage Press Association in 1895 (Fahs 275). The group was meant to join newspaper women together in the fight for suffrage. Hamm 
was an active part of the suffrage community and wrote extensively about the myriad conventions and associations that were dedicated to this cause. Moreover, Hamm idolized Elizabeth Cady Stanton, even writing a poem dedicated to Stanton and published in Current Literature in 1885 praising her "Dear Elder Sister" for her "busy fourscore years/ praise for her labor, love and tears / Self-consecrated to the good / Of universal womanhood” (526).

Hamm's "feminist sensibility" also appears in her travel-themed newspaper writing. In the wake of the Spanish American War, Hamm wrote "Woman as Travelers" for Frank Leslie's Popular Monthly in 1899. In the piece, Hamm mixes practical advice for women travelers along with essentialist assertions regarding the inherent difference between male and female travelers. Women, she argues, can travel in a number of capacities, including as a "traveling companion, the courier, the war correspondent, the foreign correspondent, the commercial traveler, the missionary, and the student, who, paradoxically enough, is usually a teacher [and] explorer” (“Travelers" 13). After this statement, Hamm immediately dismisses the role "traveling companion," noting that the traveling companion is "an annex or attachment to the traveler proper and is not a traveler per se" ("Travelers" 13). She continues by explaining how "travel brings out the deep ethical difference between the two sexes" ("Travelers" 13). Men, Hamm maintains, are flippant travelers who make a "beeline for the famous inns, pubs and music halls" in London and "frequent...the places where geishas give their songs and dances" in Japan. On the other hand, women spend their time in "flower gardens and the temples" ("Travelers" 13). This comparison suggests that Hamm not only felt that women were capable travelers, but that they were better travelers than men, who were so easily distracted by things such as pubs and geishas. Women, she continues, "have more tact and a greater regard for the rights of others," and are less likely than men to ignore or violate "native customs and religious laws" ("Travelers" 
13). In this capacity, men "sin fifty times where women do once" ("Travelers" 13). Finally, Hamm promotes the professional opportunities for women who are willing to travel: "Travel and literature combined present a fine industrial field for the educated woman" She continues, "The encroachments of civilization upon the wilds are bringing into notice and making of interest scores of places which heretofore were of no account excepting to the map-maker or the strategist” ("Travelers” 13). In this article, Hamm promotes a new public and professional sphere for U.S. women.

Hamm's “Women as Travelers" joins discourses of gender and travel. Yet Hamm's writing on foreign politics generally avoids any direct discussion of U.S. women. Despite Fahs's assertion that Hamm brought a "feminist sensibility" to her writing abroad, Hamm does not directly address the role of middle class white women in the establishment of U.S. territories abroad in her book-length works on foreign politics (252). Unlike the transparent gender politics of some women journalists like Nellie Bly, Hamm does not use her pro-imperialist writing to bolster an argument for increased women's rights in the U.S. At first glance, Hamm's writing on foreign affairs appears to avoid the topic of American women entirely. Hamm does not mention the presence of or opportunities for white women in the Philippines. She does not overtly use the plight of native women as a mouthpiece for middle-class white women's rights in the United States either. Given Hamm's public support for women's rights, the absence is curious. As noted above, Hamm felt that women were apt travelers and she promoted the professional opportunities provided for women through travel. Yet both Manila and the Philippines and America's Possessions makes little mention of the figure of the American woman abroad, which appears as almost as an opportunity missed. 
Bebell 59

Hamm only mentions U.S. women twice throughout the entire volume of Manila and the Philippines. The image of "American women" (i.e., white women) appears only spectrally in the text. For Hamm, the "American woman" does not occupy a physical space in the Philippines, but occupies a place within the imperial machine through their consumption of goods produced in the Philippines for the U.S. market. In a chapter titled "Some Native Industries," while describing the export potential of Philippine-sourced pineapple cloth, Hamm reports that "the most important of these industries from a commercial point of view is the manufacture of those beautiful tissues, pina or pineapple cloth" (Manila and the Philippines 141). "All three clothes," Hamm continues, "are known and highly appreciated by American women" (Manila and the Philippines 141). In the only other mention of American women in Manila and the Philippines, in a section titled "The Stores and Shops," Hamm explains that the meager shops of the Philippines would come as "a profound surprise to American women... accustomed to large establishments, the numerous clerks and wide assortment of goods which mark the dry goods, millinery, boot and shoe trades of the Western world" (56). In both cases, Hamm mentions American women only in conjunction with economics - as (literal) consumers of empire.

Hamm imagines U.S. women as consumers and places native women as producers. Hamm praises the native women of the Philippines for their "wonderful skill" in the production of goods such as jewelry (Manila and the Philippines 59). Considering U.S. women as consumers and native women as producers, Hamm reproduces in miniature the imperial economics that supported U.S. occupation and economic exploitation of the Philippines. There was not a large population of U.S. citizens, especially white women, in the Philippines when Hamm visited, but they were nonetheless important participants in empire building through their purchasing power in the United States. ${ }^{9}$ As such, American women could actively participate in 
U.S. imperialism in the Philippines without ever leaving the United States. As Yoshihara points out, "The encounter with, and consumption of, Asian objects turned white, middle-class women into agents of the culture of Orientalism without their having to physically travel to the Orient" (18). Yoshihara continues, "Consumption and material culture offered women a cultural, educational, and liberating experience akin to the grand tour of the world which their wealthy male counterparts undertook" (18). Whether explicit or implicit participation, American women participated in the spread of Orientalism within U.S. culture. Orientalism, the twin discourse of U.S. imperialism, turned middle-class women into consumers of empire through their literal use of goods associated with Asia. Through the role of consumer, average American women became producers of the imperial imaginary.

Even though Hamm rarely mentions U.S. women in Manila and the Philippines and America's Possessions, she does describe native women in America's newly acquired possessions. Throughout both texts Hamm describes native women as victims of savage patriarchy. Hamm notes that in Manila "neither Spanish women, nor women of other nationalities, are seen much on the street. Under Spanish etiquette, it is bad form for a women to go out walking alone, or with one of her own sex, and it is also bad form for them to be escorted by any man excepting their brother, husband or father" (Manila and the Philippines 43). Elsewhere, Hamm explains that native women are subject to "polygamy," "patriarchy," and a “general contempt for women" (America's New Possessions, 83, 131, 133). Hamm's assessment of victimized Filipinas stands in contrast to Lopez's assertion in her address that "mentally, socially, and in almost all relations of life, our women are regarded as the equals of our men" (184). Lopez even claims a long history of gender equality in the Philippines, stating that "equality of women in the Philippines is not a new thing" (184). Gender equality in the 
Philippines, Lopez continues, was not "introduced from Europe, but was innate and the natural expression" of familial love for one's mother, sister, or daughter. In this way, Lopez claims that Filipinas have in many ways already attained the social equality that U.S. women desire. She shifts the logic of imperialism, which promotes the notion that white men save brown women from brown men. Lopez clearly asserts that gender equality in the Philippines is far more affected by the lack of a free and independent nation than savage and barbaric native customs. Taken together, Lopez and Hamm represent competing narratives of the gender politics of U.S. imperialism. Specifically, Lopez dismantles the pro-imperialists' assertion (which is promoted by Hamm) that U.S. control is needed to "protect" native women from native men, thus leading to a modern/progressive society. Lopez shifts attention away from gender and instead focuses on sovereignty as prerequisite for women's full participation in public life.

While a comparison between the lack of rights among Filipinas and the plight of U.S. women would make some rhetorical sense, Hamm avoids this comparison entirely in her endorsement of U.S. imperialism. Some journalists, such as Mary Krout, used descriptions of native women in U.S. territories to draw a direct comparison between the lack of rights of both native women and American women. Unlike Krout and Hamm, other suffragists were staunchly anti-imperialist. For example, Mary A. Livermore, made an explicit anti-imperialist argument within the context of women's rights (“As Badly Off” Hoganson 27). ${ }^{10}$ Livermore insisted that the denial of women's rights and the occupation of the Philippines were two sides of the same coin. In order to gain the support of anti-imperialists for the suffragist cause, Livermore addressed the New England Anti-Imperialist League directly: "As for myself, I cannot do anything. Why I am as badly off as the Filipinos! I have for half a century been slowly, with the company of other women, trying to obtain for women the rights which you want for Filipinos- 
the right to vote, to have a voice in representation, and to effect something" (34). For suffragists like Livermore, there seemed to be an obvious connection between U.S. women and Filipinoseach were subject to the authority of white men. Convincing anti-imperialists of this was only one challenge that Livermore faced. She faced equal difficulty in convincing suffragists that antiimperialism was a parallel cause to their own.

Hamm rejected Livermore's approach, and she was not alone. Both Susan B. Anthony and Elizabeth Cady Stanton supported U.S. extraterritorial expansion. Stanton claimed that she was " "strongly in favor of this new departure in American foreign policy"” (qtd. in Griffith 259). She followed this assertion with a question: "WWhat would this continent have been if left to the Indians?"” (qtd. in Griffith 259). Hamm's stance was more closely aligned with Stanton than Livermore. It is likely that Hamm felt there was a political risk inherent in making a direct comparison between U.S. women and colonized women. In her study of the intersection of suffrage and imperialism, Allison Sneider notes that rather than asserting parallels between white women and colonized subjects (of either gender), many white suffragists "preferred to think of themselves as 'civilizers,' not as subjects of domestic imperialism” (116). The anti-imperialist argument had the capacity to challenge the often racist assertions of white suffragists. As Hoganson suggests, "the racist inclinations of white U.S. suffragists assumed international dimensions" by the late 1890s (“As Badly Off” 11). For Hamm and others who worked so hard to break down gender barriers within their chosen professions, there was a lot to lose by making a direct comparison between themselves and those colonized by the U.S. Making the comparison, rhetorically, would mean that U.S. women would need to admit the lack of progress achieved during the last decades on the nineteenth century. They felt as though this meant 
relinquishing gains they had made in the professional and political arenas. Therefore, Hamm keeps the rights of U.S. women and native women in discrete siloes.

\section{Sex and Science of Empire: Phrenology and Feminist Eugenics}

Hamm's racism undoubtedly informed her attitudes toward U.S. imperialism and women's rights. Hamm's understanding of race stemmed from her investment in scientific racism. Scientific racism, often appearing as pseudoscientific discussions of social Darwinism, eugenics, phrenology, and physiognomy, both upheld and contradicted the U.S. imperial project in the Philippines and elsewhere at the turn into the twentieth century. In short, scientific racism refers to the (often faulty) deployment of the scientific process to legitimate, degrade, and classify different races into discrete racialized categories. Inherent in this process is the elevation of one racial group (white Anglo-Saxons) over all other human races. At a glance, it is easy to see how the discourses of scientific racism assisted the U.S. colonial project. After all, if white Americans were above degenerate races in terms of physical, mental, and moral attributes, extraterritorial expansion could be promoted by pro-imperialists as a benevolent mission wherein the "uplift" of foreign peoples was seen as a dubious priority. On the other hand, the relationship between race and empire was not always a supportive one. As Eric Love argues, notions of white racial superiority often thwarted U.S. imperial ambitions abroad. Working against the dominant pro-imperialist narrative of "the white man's burden," Love asserts that many pro-imperialist policy makers "saw racism, racist beliefs, and the laws, customs, and structures that upheld the dominant social order as stumbling blocks" to empire-building (78). Race often emerged as "the most contentious" issue in public debates, often played out in the press, about the merits of moving forward with U.S. expansion into the Pacific (Love 102). The presence of the foreign races that inhabited the Philippines posed a logistic problem for pro-expansionists. Given the 
racial climate of the U.S. at the turn into the twentieth century, it was difficult for proexpansionists to convince the American public that the Philippines was of value to the U.S. This reluctance to incorporate foreign peoples into the U.S. is evidenced by the terms of the U.S. occupation of the Philippines. As Senate deliberations concluded in 1899, the decision was not to annex the Philippines. Instead, the Senate deemed the Philippines an "unincorporated territory" administered through an insular government. The ruling denied U.S. citizenship to over ten million Filipinos on the grounds that they could never assimilate into white America (Love 164). Politicians and writers relied upon the discourses of scientific racism, which were widely used to make foreign populations knowable (and manageable) to the American public and worked to destabilize the threat felt by many white Americans about the Filipino "other." In his study of visual culture imperialism, David Brody notes that "these ethnographic renderings of a putatively uncivilized Filipino...translated into cultural inferiority, an inadequacy that many claimed should be avoided and others could be enhanced through benevolent assimilation" (64). Certainly, Hamm deploys the image of the uncivilized Filipino. She uses scientific racism for two purposes: to promote and legitimate U.S. empire and to promote and legitimate her role as “expert” on U.S. empire. In other words, Hamm masters (pseudo) scientific discourse to demonstrate the extent to which U.S. women could actively participate in the political sphere. In both America's New Possessions and Manila and the Philippines as well as her newspaper writing, Hamm presents the "racial types" that occupy various locations of U.S. empire and "spheres of influence." Hamm's work in the area of categorizing the racial types of the Philippines won her praise and acknowledgment among eugenicists and phrenologists in the U.S.; in fact, in December of 1898, The Phrenological Journal and Science of Health featured Manila and the Philippines as their "Book of the Month." Manila and the Philippines is praised 
as a "book of thrilling interest" about "Uncle Sam's new possessions in the far East" (197). According to the article, "students of ethnology and anthropology will find the first extensive discussion of the many races and sub-races which inhabit the Philippine archipelago" (197). Hamm's volume, the article continues, debunks the "popularly supposed" notion that the islands are occupied by a single Malaysian population. Instead, readers of Hamm's work will learn that "the inhabitants of the islands are a strange mixture of varying races, white, yellow, brown, dark brown, and black; of different states in civilization" (197). Moreover, the article praises Hamm's work on the basis of its accessibility to "general or special" readers.

Hamm contributes to the imperial imaginary through her "extensive discussion" of the racial types of those living in the Philippines. Through her descriptions of the places, and peoples, of the islands, Hamm literally produces the very images that she takes as an a priori fact. Most of her racialized descriptions are dependent upon physiognomy as in the following passage:

Malays, who are tall, dark, muscular men, averaging about five feet four, and some reaching as high as five feet eight inches. They are active, energetic but are said to be untruthful and dishonest. Those of the coast and in the lowlands are much smaller, averaging about five feet in height, of thinner build, and smaller muscular development. They are not very strong, but are very lazy. They work half-heartedly, and get tired quickly. They are good natured, taking nothing seriously. They make poor workingmen, but, on the other hand, they are said to be singularly affectionate, loyal, truthful, and honest. (Manila and the Philippines 81)

Hamm mixes physical characteristics as they relate to non-physical characteristics, like work ethic, which is typical of writing at this time and an example of physiognomic reasoning. These 
descriptions often follow a similar pattern—physical description of height, build, and skin color, followed by moral strengths and flaws. Not coincidently, skin color correlates to level of civilization. In her description of a "brown race" called the Garoti, Hamm notes that this race "are believed to have been the race that immediately succeeded the original negroid stock, and preceded the Malay stock" (Manila and the Philippines 80). In this explanation of the evolution and development of Filipino races, the Garoti, the closest link to "the original negroid stock," "preserve, even to-day, many, if not most, of their savage rights, ceremonies, and superstitions" (Manila and the Philippines 80). This particular racial group, Hamm reports, "have not improved greatly in the three hundred years" of Spanish rule and thus pose a threat to the modernization of the Philippines under U.S. tutelage. Hamm asserts that even the most degenerate of Filipino races can be assisted toward civilization under the direction of the United States via "education" (Manila and the Philippines 83). So, along with the "natural" state of the degenerate races, the Spanish colonial infrastructure is blamed for the lack of advancement among the lesser races of the islands.

Hamm uses physiognomic descriptions of racial types and bloodlines as another means of imperial mapping. However, this time rather than mapping geography (as described above), Hamm maps meaning onto Filipino bodies. Hamm takes part in the media's depiction of the Philippines as a "visually curious site where civilization did not exist and all that could be found was the taint of exoticized bodies, odd costumes, and contaminated blood" (Brody 61). For most turn-of-the-century readers, familiar with the slavery-era "one drop rule," the notion of bloodlines informed their understanding of race. Many white Americans saw bloodlines as “indicators of racial typology" (Brody 70). The press circulated images of blood as carriers of disease in the Philippines (Brody 70). More specially, discussions of "mixed" and 
"contaminated" blood dominated images of Filipinos. These articles and visual images are a reflection of the intense anxiety Americans felt with regards to racial mixing and miscegenation. In the U.S., laws prohibited miscegenation and the Philippines became known for large populations of mestizos and populations of mixed descent. Hamm makes frequent mention of the "half-breed" and "mestizos" throughout Manila and the Philippines $(93,91)$. Hamm explains that "the Philippines from time immemorial have been the battleground of many races. On Luzon there have been a Negroid race, a Papuan race, two Malay, Chinese settlers, Japanese, and Spanish" (Manila and the Philippines 22). She continues, "None of these races have kept themselves aloof from others, and each and all have blended and reblended, until in the course of time men and women have been produced in whose veins was the blood of at least six different or anthropologic types" (Manila and the Philippines 22). While racial mixing under Spanish colonialism was the norm in the Philippines, Hamm's insists that "[t]here is in Manila the same prejudices or superstitions that is found in many part of this country, namely, that half-breeds generally combine the vices of both parent races" (Manila and the Philippines 23).

In the context of the Philippines, "half-breeds" cued the act of miscegenation in the mind of many Americans. The mestizos and half-breads appeared to make visible miscegenation perpetrated through immoral (or unnatural) sexual acts. Interestingly, Hamm seems to give the "children" of such circumstances a break, claiming that "the real meaning" of the presence of half-breed is "that the half-breeds represent the unrighteous living of the men who make the declaration" (Manila and the Philippines 23). Hamm continues to use the discourse of phrenology and racial mixing in her discussion of other places as well. In America's New Possessions, Hamm's description of a “typical” Puerto Rican household structure is telling. Before explaining the household structure, Hamm notes that the "racial variety is best seen in the 
shape and proportion of Porto Rico heads, male and female. They range all the way from the oval face and dolichocephalous skulls of the old Visi-Goths conquerors of Spain, to the square, flat face, flattened nose, narrow eyes and brachycephalous skull of the low Ethiopian" (America's Possessions 82). Hamm literally maps the history of empire onto the bodies of Puerto Ricans. What follows the physical description is the assertion that most Puerto Ricans live in "true patriarchal style" and that "the men have been very immoral" (America's Possessions 83). Therefore, according to Hamm, to an "American visitor it as shocking as it is surprising to enter a native household and find two sets of children, one white and the other mulatto" (America's Possessions 83). This is made all the more shocking since Puerto Rico and the Philippines are, according to Hamm, "Christian lands" (Manila and the Philippines 26).

Hamm maintains that men, through their lascivious and immoral behavior, create the social ill of the half-breed. Hamm is not referring just to the sexual practices of Spanish or native men either. She is likely alluding to U.S. servicemen's "illicit" sexual behavior with native women in both Puerto Rico and the Philippines. In the U.S. press, discussions of prostitution in the territories were linked to discourses of disease, contagion, and miscegenation. U.S. reform groups, including the International Reform Bureau, maintained that the "social evil" of "prostitution must be eliminated from American-controlled territory" (Tyrrell 123). However, the U.S. military thwarted "the social purity campaign" through the regulation and licensing of prostitutes in the Philippines, which led to the "de facto government recognition of prostitution" (Tyrrell 124). ${ }^{11}$

Hamm was too genteel to directly address the issue of prostitution but nonetheless participates in the surveillance and policing sexual acts between white men and brown women. Hamm's comments on "colonial intimacy" reflect the biopolitical micromanagement of empire. 
In his study of "imperial feminism," Roland Santos Coloma adapts Gayatri Spivak’s now famous articulation of imperial justification "white men saving brown women from brown men" to "white women saving white men and brown women from each other" to explain the role of white women in the Philippines (Spivak 296-297; Coloma 243). Coloma traces how U.S. women missionaries policed "white men's moral and sexual degeneracy" while constructing "brown women as sexually available and libidinal temptations to white men" (243). Coloma traces white women's efforts to discipline these transgressions through the rhetorics of public health and antiimperialism. White women asserted "superiority over white men and brown women by becoming bearers of racialized heteronormative traditions and feminine respectability by becoming barriers to inter-racial sexual relations" (245 emphasis mine). In Hamm's case, white women served a symbolic role as carriers of "normative family traditions" and bulwarks against white male sexual corruption. "Half-breeds" were evidence of the failure of morals and a threat to whiteness, which caused an already racially charged U.S. society to fear and prohibit racial mixing. Hamm's explanation of half-breeds shows the extent to which not only racial ideologies in the U.S. were transposed in discussions of new acquisitions, but also the discourses of gender and sexuality. In her disciplining of "the erotics of empire," Hamm asserts her transnational moral superiority both at home and abroad. ${ }^{12}$

The discourses of ethnology, phrenology, social Darwinism, and others within the "scientific" realm, are areas where race, gender, and sex intersect, clash, and constitute one another. Hamm relies heavily on the discourses of scientific racism, which were common at this time. Yet Hamm's use of these discourses seems to contradict her feminist politics. This is not to say that white American women did not normally use scientific racism when describing nonwhites, but that scientific racism was also applied to white women in arguments for and against 
suffrage. Some women's rights activists deployed "eugenic feminism" in their arguments for political rights (Ziegler 213). In short, the argument of feminist eugenics posited that "the decline of the [white] race could be prevented if and only if women were grated greater political, social, sexual, and economic equality" (Ziegler 213). This line of argument correlated gender equality with the racial politics. In terms of eugenics, white women were charged with "the responsibility to produce the coming race" (Derereux, para. 6). Therefore, some suffragists deployed "feminist eugenics" to argue that "society had the responsibility to empower [women] to do that work" (Derereux, para. 6). At the same time, in order to support this argument, women were subject to the very eugenic-based arguments that were used to delimit their rights. For instance, the same discursive construction of non-whites through the language of scientific racism was applied to women, suggesting the "nature of women" as "licentious, neurotic, or otherwise deviant" (Ziegler 214). The "eugenic fitness" of white women was generally assessed based upon sexual reproduction. Women without children, like Hamm, were seen as eugenically unfit for promoting and preserving the white race. Eugenicists claimed that both education and professions for women compromised the "eugenic fitness" of women because it obstructed their role in the reproductive process. Alas, intersections of feminism and eugenics proved to be "inherently contradictory" when examined outside of its application to non-whites (Ziegler 219).

Phrenology, a sister pseudo-science to eugenics, was a key characteristic of writing about race and gender at the turn into the twentieth century. The phrenological community praised Hamm's Manila and the Philippines, as seen in the glowing review that appeared in the Phrenological Journal in December 1898. In September of that same year, the Phrenological Journal published a different article wherein the phrenological gaze is reversed and mapped upon Hamm, who is herself the subject of the article. J.A. Fowler's "Margherita Arlina Hamm: 
The World Renown Journalist and Her Inheritance" commends Hamm for her "brainy achievements in journalism" (82). Fowler describes the "indefatigable traveler" through a discussion of Hamm's “inheritance.” Here inheritance refers to characteristics and qualities inherited from one's parents or ancestors, either physical or mental. Fowler uses the discourse of inheritance to trace Hamm's bloodlines, noting that Hamm “on her mother's side [is] a direct descendent" of philosopher Herbert Spencer. Hamm's association with the Spencer family, Fowler continues, explains her exceptional "cerebral power" (82). Once Fowler establishes Hamm's Spencerian bloodline, he turns his attention to her physiognomy. In between the text of the newspaper article are two large photos of Hamm; in the first shot, Hamm's head is facing the camera, though her gaze is averted. In the second picture, placed side-by-side with the first, is a side profile picture of Hamm. The juxtaposition of the photos is very similar to the ethnographic side-by-side photos of natives that Hamm and others included in their depictions of foreign lands. Fowler spends the rest of the article "reading" Hamm's physical features, and identifying her mental aptitudes, and is worth quoting in full:

When having the pleasure of interviewing her I found her head exceptionally well developed in the anterior and superior portions, while her features are very small and refined, as will be seen by her new and special photos taken by Rockwood for the Phrenological Journal....She has a wonderful memory, and is able to recall experience and historical events. This is not owing to the activity of one faculty only, but several, such as Eventuality, Individuality, Comparison, and Locality; all of which have their distinct memory. (82 Fowler)

Here, the gaze is reversed, and Hamm becomes the object of scientific study. Fowler notes the "pleasure" he feels when examining Hamm's head. This scopic pleasure wherein Hamm is the 
object suggestions how tenuous the position of white women, even those with professional authority, really was in the U.S. While women reporters, and travel writers, utilized scientific racism, they too were often subject to the very same discourse. While Fowler's article seems to reify Hamm, the subtext dictates that Hamm is indeed a rare exception — an exceptional specimen of her sex. Moreover, it shows the extent to which women's bodies, including Hamm's, were subject to critique by the very disciplines they upheld.

From a practical perspective, Hamm's supposed “exceptionalism” suggests that most other women, who lacked the same prestigious bloodline or fine skull shape, were not suited for public or professional life. Hamm's very presence in the field of journalism, and the large number of other female journalists and professionals, suggested otherwise. Nonetheless, rather than seeing Hamm's success as evidence of women's equal ability in the field of journalism, the phrenological community presents Hamm as an atypical exception to firmly held gender standards. Often phrenologists had no problem assigning characteristics to entire populations through a handful of examples based upon their methods. But when it comes to a white, middleclass American women, the journal maintains that these positive characteristics and abilities are unique to Margherita Arlina Hamm.

The "exceptional" status assigned to Hamm by the Phrenological Journal oddly coincides with Hamm's own preoccupation with the notion of exceptionalism within the context of U.S. empire. As demonstrated, Hamm felt no need to apologize for U.S. imperialism, particularly regarding the territories acquired following the Spanish American War. Hamm argues that U.S. expansion was the only antidote to damage done by Spanish imperialism. As a bonus, Hamm notes that the consolidation of overseas empire promotes national unity. Hamm's contribution to the imperial imaginary promotes the narrative of American exceptionalism, 
which continues to inform contemporary politics. She asserted with absolute certainty that the territories acquired via the Spanish American War were just the latest additions in what would be a long and continued trajectory of national growth. While Hamm maintains that "prophecy is an unsafe steed for any writer," she proclaims that "the trend of events indicates that the West Indies, in whole or large part, and Northern Mexico will in the course of time be added to the national domain, that if the Nicaragua canal can be built the same destiny will await the little Central American Republic, that Samoa, the Ladrones, and other Pacific Islands will follow in the footsteps of Hawaii” (America's Possessions 10). Ultimately, in Hamm's imperial fantasy, the end game is China. She predicts that "American concessions in China will expand into a zone or sphere in influence" (America's Possessions 10). "Already," Hamm writes, "Uncle Sam appears upon the books of the Chinese government as the owner of at least five thousand pieces of property" (America's Possessions 244). Hamm's imperial fantasy culminates with the "partitioning" of China "among the great powers of the West" (244). In this case, Hamm asserts that the "United States would be in a position to demand with perfect right and justice an area of land twice as large as that taken by Germany at Kiao-Chou...for the extension of U.S. markets" (America's Possessions 244). U.S. imperialism in the Philippines and Hawaii provided a foothold in the Pacific and a path toward the future that Hamm imagines. In many ways, Hamm's prophecy wasn't far off. China has remained a defining factor in U.S. foreign economic policy as "globalism" replaced "imperialism" as a way to describe economic and political relations between what Stuart Hall famously articulated as "the West and the rest" (305). The United States' preoccupation with Chinese markets has been a defining feature of the twentieth and twenty-first centuries. 


\section{Chapter Three}

Little Ladies Locate the Pacific: Mary Krout's Alice's Visit to the Hawaiian Islands and U.S. Imperialism in Turn-of-the-Century Children's Geography Primers

\section{Introduction}

In an 1893 column titled "The Home Circle," published in the Chicago Daily Inter Ocean, Mary Hannah Krout, a regular columnist for the paper, argued that the "best citizens" were those who traveled abroad. "The most enlightened," she argued, "were not those who have lived a lifetime under one roof or spend the most time within doors" ("Home Circle" n.p.). Travel, she maintained, was the key to a "liberal education" ("Home Circle" n.p.). "Next to the university, and rivaling it in some essentials, the world is the greatest of educators," she wrote ("Home Circle" n.p.). Krout concluded that only a "citizen of the world learns, as none other ever can learn, how much excellence there is there is in humanity at large - that even those condemned as hopelessly barbarous show virtues that the civilized might imitate with profit" ("Home Circle" n.p.). A school teacher turned journalist, Krout felt she knew a thing or two about education and travel. She had traded the schoolroom for the steamship, and now compelled other American women to do the same, but what did this "liberal education" acquired through travel really entail? What did "The Home Circle," a column which appeared on the women's pages and clearly devoted to domestic life, have to do with travel and education? The article signaled the intersection of U.S. women's rights, travel, and education as Krout imagined it. By the late 1890s, the domestic boundaries of the home — and nation-were expanding. U.S. women were actively engaged in Progressive Era reforms and women's rights groups became increasingly visible and active in the public sphere. Women's rights groups, to which Krout was firmly committed, demand increased opportunities for education, professional advancement, and 
political agency for white women. A drastic increase in women's travel, and the innate sense of mobility associated with travel, facilitated these social and political changes. Further, the 1890s signaled a new age in U.S. empire-building wherein the U.S. looked beyond its own borders to territories in the Pacific and West Indies. In 1893, four months before the "Home Circle," Krout traveled to Hawaii with an "ardent desire" to witness history in the making — the U.S. backed overthrow of the Hawaiian monarchy (Hawaii and a Revolution vii). ${ }^{1}$ U.S. empire-building, then, provided a space for U.S. white women to assert themselves as political agents and professional equals.

Krout took seriously the assertion that travel and education were intimately linked. After becoming a self-titled foreign correspondent, and traveling to Hawaii in 1893, Krout published extensively on Hawaiian "affairs" in an effort to educate the American public regarding Hawaii's shift from "a semi-barbarous monarchy" to an "advanced state of intelligence and wholly prosperous self-government" (Hawaii and a Revolution vii). As historical hindsight shows us, a “prosperous self-government” wasn't in Hawaii's future. Rather, after the 1893 establishment of a provisional government comprised of wealthy U.S. planters under the direction of Sanford Dole, the U.S. officially annexed Hawaii in 1898 - the same year as the Spanish American War and the subsequent imperial acquisition of Guam, Puerto Rico, the Philippines, and, to an extent, $\mathrm{Cuba}^{2}$ Krout sent dispatches to the Chicago Inter Ocean throughout the conflict of 1893 . In 1898 once annexation was official, Krout combined her 1893 dispatches and published Hawaii and a Revolution: The Personal Experiences of a Correspondent in the Sandwich Islands During the Crisis of 1893 and Subsequently. That same year Krout's work on Hawaii appeared in several literary magazines and periodicals including a series of articles titled "The United States and Hawaii," which appeared in The Chautauquan between January and May 1898. 
Two years after annexation, Krout adapted Hawaii and Revolution into a geography primer for a new audience: U.S. school children. She titled the primer Alice's Visit to the Hawaiian Islands. ${ }^{3}$ In the preface to Alice's Visit, she states that "it is important that children in our schools should learn something of the geography of these islands, and of the manner, customs, and history of the people who inhabit them" since "the Hawaiian Islands have now become part of the United States" (7). Krout's phrase "part of the United States" carries domestic connotations that efface and simplify the reality and brutality of Hawaiian annexation. Alice's Visit white-washes the imperial overthrow of the Hawaiian monarchy and explains that prior to U.S. annexation, Hawaii, while rich with natural resources, was a diseased and savage wasteland. Krout asserts that prior to U.S. influence Hawaiians lived perverse domestic lives. In Krout's opinion, pre-annexation Hawaii was a place where native women were abused by native men, there were uncontrolled disease epidemics, and rampant acts of infanticide. Through a combination of geography lessons and narrative, Krout enthusiastically endorses U.S. imperialism in Hawaii just as she did in Hawaii and a Revolution.

Alice's Visit to the Hawaiian Islands constitutes an experiment in U.S. imperial pedagogy that makes U.S. empire-building central to children's education. I argue that Alice's Visit provides U.S. children with a pro-imperialist and a pro-(white) feminist education — an education in foreign politics with a subtext devoted to an argument for the advancement of white women's rights. Alice's Visit functions not only as a mechanism for teaching the geography and customs of the newly acquired U.S. territory and legitimating unquestionable U.S. ownership over Hawaii, but it is also functions as an endorsement of what Louise Newman calls white women's “civilization work" (52). Through combined rhetorics of social evolution, women's rights, and imperialism, white women found new social and political roles as "civilizers of the race," which 
strengthened "long-standing beliefs in (white) women's moral superiority" over non-white women and men (Newman 52). In other words, white women could and did use the opportunities provided by U.S. imperialism to deploy arguments for women's rights in the United States. Krout's choice of a girl protagonist in Alice's Visit is instructive. Alice's presence on the Islands, along with her family who are an ideal picture of U.S. domesticity, show that even girls must contribute to the civilizing work of U.S. empire. In her account of the history of U.S.-Hawaii relations, Krout places women and girls as avid historical actors, travelers, and participants in discourses of imperialism within an international context. Moreover, Alice's Visit suggests the extent to which U.S. school children were expected to accept and participate in discourses of U.S. expansion in the Pacific and beyond. ${ }^{4}$

School primers fall into the general category of children's literature. Many scholars have dismissed this genre as non-literary or unworthy of serious academic attention. The tendency of scholars to relegate primers to the margins of literary study partially results from a reluctance among academics (and society) to view children as more than "passive receptors of culture" or, worse, “culturally irrelevant” (Sanchez-Eppler 5). As Karen Sanchez-Eppler, James Kincaid, and others have argued, children (and by extension children's reading materials) deserve a place within literary and cultural studies. Literary critics and historians too often view school primers, which have existed since the country's inception, as "fragile, cheap and unaesthetic" massproduced scraps (Venezky xi). These opinions dismiss primers for their ubiquity, which, ironically, is the very reason they deserve careful consideration. Primers, and geography primers in particular, constituted official instruction in primary school curriculums. "Primers," a catch-all term used to describe an educational textbook that presents basic information on a particular topic, appeared in a variety of forms and on a variety of topics. The structure and content of U.S. 
primers changed over time, but were generally influenced by three variables: theories of psychology of education (how do children learn?), the market place (what will sell?), and hegemony (what is pertinent at that historical moment?). Primers were didactic and typically in line with the hegemonic agenda of U.S. culture at the times of publication.

Primer content changed drastically in the 1890 s. ${ }^{5}$ This shift was influenced by the increasing U.S. interest in travel, social evolution theories, Progressive Era initiatives, and imperial expansion. By the end of the nineteenth-century, geography primers increasingly appeared as travelogues that presented "factual accounts" of a region through narrative (SandsO'Connor 76). Primers like Alice's Visit literally redrew domestic boundaries and fostered the formation of children's "national identity" through the nexuses of geography, gender, race, and religion (Sanchez-Eppler 186). Primers trained U.S. children in the ways of empire. ${ }^{6}$

As I noted in the previous chapter, the discipline of geography, and by extension geography primers, operate under the guise of unbiased "scientific" spatial truth, which interpellates readers into seeing the world in a particular way. In the nineteenth century, as the U.S. expanded its borders, the field of geography evolved, as did the demand for children's geography books (Smith 4). ${ }^{7}$ Yet as Edward Said reminds us, the transmission of geographical knowledge is never merely the transmission of factual, unmediated historical knowledge. Rather, Said explains that "none of us is outside or beyond geography, none of us are completely free over the struggle for geography" (Culture 7). Alice's Visit demonstrates that the struggle over geographical knowledge "is not only about soldiers and cannons but also about ideas, about forms, about images and imagining" (Said, Culture 7). In Alice's Visit, Krout puts forth her own images and imaginings of the world through the lens of U.S. expansion and women's rights. This type of geo-literacy, deployed in the domestic space of the U.S. schoolroom, reflects covert and 
explicit commentary on late-nineteenth and early twentieth-century attitudes toward imperialism, gender, and race in both domestic and foreign contexts. As such, geography primers became crucial contributions to nation-building and self-definition (Smith 133).

By considering Krout's primer one can also address the absence of female-authored primers within academic discussions of this genre. The marginalization of women-authored primers reflects a broader trend within the historiography of geography that ignores the work of female geographers and travelers such as Isabella Bird (one of Krout's cited influences) (Domish 95). Krout, along with other female travelers, contributed to the discourse of feminist geography. ${ }^{8}$ This is not to say geographies by women are somehow essentially different than those written by men; rather, the context and conditions in which they are produced tended to differ significantly (Mills 31). "Internationals," books for kids that focused on settings outside of the U.S., often used de facto masculine paradigms of travel and conquest - like those found in the famous Robinson Crusoe stories where an exotic setting provides "the testing ground for masculinity" (Singh 35). These texts presented the process of national expansion—made possible through military and economic engagement - as a masculine endeavor (Adas 139). Krout's choice to place Alice, a young white American girl, at the center of her narrative challenges the above paradigm and reflects Krout's unwavering feminist politics in the U.S.

Almost forgotten by twenty-first century readers and scholars, Krout was a well-known “trailblazer of the women's newspaper business," in addition to a well-known writer and lecturer on the suffrage circuit (Zach 133). ${ }^{9}$ To date, there is not a single sustained critical examination of Krout's life or work, despite her contemporary popularity and relevance within the fields of women's rights and U.S. imperialism. She began her professional career as a school teacher in her home state of Indiana. Later, she shifted professions to an area newly open to women: 
Bebell 80

journalism. Her first job as a journalist was for her home-town paper the Crawfordsville Journal in 1881. Later, she edited the Terre Haute Express, and finally spent ten years on the staff of the well-respected and widely-circulated Chicago Inter Ocean (Who's Who 649). At the Inter Ocean, Krout edited a column dedicated to women's issues titled "The Woman's Kingdom" throughout the 1880s and 1890s. In her column, Krout fiercely defended the "New Woman" and "Bachelor Girl" as alternatives to the previous generation's attachment to "True Womanhood" and the stereotype of the "old maid." The "bachelor girl," a label Krout applied to herself, was "a product of modern opportunity and civilization" ("The Woman's Kingdom" 11). She described the ways that bachelor girls "crowd the school-room, the colleges, the professions" ("The Woman's Kingdom" 11). Along the same lines, Krout founded and joined several politicallyminded women's groups. Like Hamm, Krout had occasion to meet and work with the leading figures of the suffrage movement. Susan B. Anthony praised Krout for her participation in the Woman's Congress in May 1893. In a feature for Peterson's Magazine, fellow journalist Hamm praised Krout for "excellent work" as a "lady editor" reporting on "the life of other nations" (“Some Women Editors” 609). Hamm acknowledged Krout's former career as a teacher and explained that Krout's "writings were so much appreciated that she gave up pedagogy and took up the pen for a profession" ("Some Women Editors" 609). However, Hamm was incorrect; Krout didn't give up "pedagogy" for “the pen.” Instead, Krout joined the domestic goal of pedagogical instruction with her interest in "life of other nations," thus joining together domestic and foreign concerns in the space of a school textbook and in the service of U.S. imperialism.

To most readers, Krout's racial politics will appear far less progressive than her gender politics, which is indicative of broader racial divisions within the U.S. women's movement and U.S. culture generally. Krout considered herself a "progressive republican," and likely felt that 
her racial politics were progressive compared to those of mainstream U.S. society (Fahs 265). At the same time, Krout likely shared Susan B. Anthony’s thought that “'I have but one question, that of equality between the sexes - that of race has no place on our platform"' (qtd. in Newman 4). Despite Anthony's assertion, women's rights and racial equality were intimately intertwined, even if, as Anthony thought, politically separable. White women developed "specific relationships" between gender and race that ensured the "white woman as the primary definer and beneficiary of women's rights" (Newman 5). Like many other white feminists, Krout relied upon social evolutionary theories of racial advancement to uphold white racial privilege. Social theories of evolution, as Newman and Gail Bederman argue, did not totally eliminate the possibility for future advancement of non-white races, but simultaneously posited that AngloSaxons were the most civilized among the world's races. White women's relationship with and deployment of social evolutionary theories, as shown in the previous chapter, was complex. Dominant culture promoted white women as "mothers" and "conservators" of the white race. As immigration and urbanization increased, this role took on more urgency. Imperialism was a crucial factor too; the annexation of Hawaii and the Philippines could also potentially lead to the degeneracy of the white race (Newman 17). ${ }^{10}$ As Newman asserts, and as Krout's work attests, “feminism developed in conjunction with — and constituted a response to - the United States' extension of its authority over so-called 'primitive' peoples" at home and abroad. This rationale allowed Krout to make an argument for the "uplift" of Hawaiian women while simultaneously applying racialized logic to explain (and maintain) their inferiority.

\section{Imperial Pedagogy: Domesticating the Foreign}

Primers like Alice's Visit are overt tools of didactic instruction that interpellate children into future U.S. citizens. As such, primers present a particular historiography — one that is often 
in-line with the dominant socio-political narratives. In the case of Alice's Visit, and other primers meant to instruct children regarding new territorial possessions, the primer imbued U.S. school children with an imperial education. In Alice's Visit, children receive a particular history of Hawaii in which U.S. imperialism becomes an uncontested site of U.S. benevolence. Native Hawaiian resistance to U.S. rule is masked or framed as barbarous rebellion. Alice's Visit is one of several U.S.-produced works of "historiography" that perpetuates what Noenoe Silva considers "the most persistent and pernicious myths of Hawaiian history," that of native nonresistance to U.S. imperialism (2). Despite active anti-American resistance movement in Hawaii, and anti-annexation movements in the U.S., Krout tells the story of U.S. colonization in Hawaii as a natural extension of U.S. borders through the language of American exceptionalism. In 1898, the year the U.S. officially annexed Hawaii, Krout contributed a series of articles in The Chautauquan wherein she acknowledges that "in the course of its history the greater republic has steadily opposed any acquisition of territory beyond the actual coast to the east and west" (176). However, Krout argues the exceptional case of Hawaii and exceptional status of U.S.-Hawaiian relations. Unlike Cuba, where the U.S. "in not inspired by any desire whatever to secure possession," Krout claims that U.S. "relations" with Hawaii are "radically different from those between the United States and the West Indies" ("U.S. and Hawaii I" 176). "Hawaii," Krout asserts, is "already practically an American colony with a civilization that is essentially AngloSaxon" ("U.S. and Hawaii I" 176). Taking this rationale one step further, Krout concludes that "what may be known as American influence" marks Hawaii with "a touch of romance to what otherwise would be an almost unrelieved record of bloodshed and violence" ("U.S. and Hawaii I" 176). 
The mutually constitutive notions of American exceptionalism and manifest destiny that inform Krout's books for adults also infuse her primer. Krout begins Alice's Visit with a Preface that states her intended goals in the primer. "In writing this imaginary journey," Krout writes, "I have described the country and the people as they were studied by me during two actual visits" (7). However, she reveals that the study of Hawaiian "evolution affords such a variety of incident that it is somewhat difficult to decide, in preparation of a book for children, what to reject and what to utilize" (Alice's Visit 7). "It is necessary, on one hand," she continues, "to consider the importance of customs in shaping the destiny of the people, and, one the other hand, to bear in mind the consequence of filling the impressionable minds of children with painful images and with facts that they cannot reconcile with justice" (Alice's Visit 8). Here, Krout considers "painful images" as those that depict pre-U.S. Hawaiian "customs" or pre-U.S. attempts by other nations to exert control over the Islands. In no way does Krout mean to signal the injustice felt by the majority of native Hawaiians at U.S. political, economic, linguistic, and cultural control over what once was a sovereign kingdom. She explicitly dismisses the view that U.S. annexation in Hawaii was an overt act of imperial aggression in direct violation of the Monroe Doctrine. Rather, Krout argues that "the native Hawaiian has been an object of much misplaced sympathy on the part of those who know nothing of Hawaiian affairs, or, who are, at best, merely superficial and not wholly disinterested observers" (Hawaii and a Revolution vii). Initially, Krout traveled to Hawaii in 1893 "prejudiced in favor of the natives" and "deeply sympathizing with them because of they had been disposed of their lawful possessions" (Hawaii and a Revolution ix). However, "after careful and conscientious study of the situation," she changed her views "absolutely" (Hawaii and a Revolution ix). She concludes that all U.S. offenses toward native Hawaiians were done "of necessity and with wisdom and forbearance" (ix). Alice's Visit 
promotes Krout's pro-imperialist political views and presents the U.S. annexation of Hawaii as an act of justice and necessity.

What specific lessons were children meant to learn in Alice's Visit? First and foremost, children learn that U.S. control over Hawaii can be subsumed under the general rhetoric of manifest destiny and American exceptionalism. In other words, children learn the lesson of imperial ownership. This lesson begins in the front matter of the primer, which contains a map of Hawaii's major islands. It appears before the title page and geographically situates young readers immediately. The placement of the map suggests the territorial agenda of the primer. The appendix of Alice's Visit is equally revealing. It contains a guide titled "Pronunciation of Hawaiian Names and Terms," which explains that "a is sounded as in far; e as in prey," and so on (n.p.). Following the guide is a list of common Hawaiian words that are used throughout the primer. Seemingly innocent, the pronunciation guide is in fact an important teaching tool and imperial gesture. Verbal recitation required children to make what Martin Bruckner describes as "geographical noises" (178). Bruckner explains that "for the duration of an oral geography lesson, as place names, coordinates, and territorial sizes wafted through American parlors and classrooms, students not only learned how to noisily claim a common geographical identity but also practiced how certain geographical noises extended to territorial rights" (178). This gesture reinforces and challenges "other linguistic markers that had traditionally focused on birthrights (biology) and cultural rights (history)" (Bruckner 178). Through the process of verbal recitation, students claimed linguistic ownership over Hawaii. From the domestic space of the U.S. classroom, children became miniature imperialists through discursive colonization via their mastery of maps, sounds, and history. 
Bebell 85

In addition to imperial ownership, U.S. schoolchildren learn a lesson in American exceptionalism via Alice's Visit. The text differentiates between U.S. and European expansion in Hawaii. For example, in the chapter titled "The Story of Captain Cook," Alice learns that the British were typically met with quarrels, violence, and disaster: "Quarrels between the English and natives grew more frequent every day, and when Captain Cook and his party finally sailed away, the Hawaiians were very glad to see them go" (Alice's Visit 101). When Cook and his party return they are met with "a cold welcome" until the native "killing" of Captain Cook (Alice's Visit 102). On the one hand, as Krout tells it, Hawaiians appreciate and value U.S. presence for the supposed betterment and civilization of the Islands. Rather than bringing death and destruction like Cook, Krout explains that a "network of Americans" (mainly missionaries and businessmen) improved infrastructure and quality of life throughout Hawaii. According to the primer, the U.S. alone is responsible for the uplift and modernization of an otherwise backward and savage Hawaii. Krout uses the example of transportation to illustrate this point: "People who once had to go back and forth on horseback, over the lava, were glad enough to have any sort of railway by which they could go quickly, and without fatigue" (Alice's Visit 57). Alice even finds that there are modern "telephone lines" that connect the towns with the plantations. What Krout doesn't reveal is that these modern improvements are integral aspects of colonial infrastructure used to exert control and extract economic benefits.

Overall, Krout presents Hawaii to U.S. schoolchildren as a place nearly totally domesticated by the U.S., thus presenting Hawaii as clean, sanitary, appropriately white, with subdued and pleasant natives. The primer begins by introducing Alice Earle, a "clever little girl" whose parents "decided to take her with them on a visit to the Ha-wai' an Islands" (11). The Earle family is an ideal picture of normative U.S. domesticity, which Krout contrasts with the scenes 
of native life that Alice encounters. As the family travels, they trace the westward path of U.S. expansion. They travel from Chicago to San Francisco by "Pullman car for long ride from Chicago to California" (Alice's Visit 13). The ride might have been long, but the Earles travel in relative comfort in the Pullman car-a signal of their upper-middle class status. As they cross the Mississippi, Alice is "much interested in the pretty towns and villages in Iowa," and marvels at "the Sierra Nevada Mountains" before descending into the Sacramento Valley (Alice's Visit 14). Finally, Alice and her parents board the steamship Miraposa (Spanish for "butterfly"), signaling the transformation Alice undergoes as she travels across the Pacific to Hawaii. Alice's family moves toward the western frontier (which, in 1893 Frederick Jackson Turner deemed officially "closed") to the next seemingly logical location: Hawaii. In addition to an articulation of manifest destiny, Alice's journey signals the beginnings of what would become massive U.S. tourist activity in Hawaii. According to Alice, visits across the Atlantic have become passé when compared to traveling through the Pacific. The journey across the Atlantic is "rough [with] much fog and rain" (Alice's Visit 16). Instead, Alice prefers the "air of the Pacific," which "was as warm and soft in February as in June" (Alice's Visit 16).

The Earles represent a domesticating force in Hawaii that symbolically signals the cultural emphasis placed on the family as "the principal, moral, and social organizing unit of the nation" (Sanchez-Eppler xv). So, while Hawaii is clearly an "exotic" locale peopled with "queer" natives, it is "domesticated" enough to host a white upper-middle class American family who themselves represent the ideal U.S. domestic scene (Alice’s Visit 104). Amy Kaplan's configuration of manifest domesticity is instructive here. Manifest domesticity, an alternative framework to manifest destiny, takes into account "the imperial reach of the domestic sphere" (48). In this case, the domestic family unit travels to "out of the way places not often visited by 
travelers," and promotes, in miniature, the legitimacy of U.S. political presence and domestic presence in Hawaii (Alice's Visit 104). In one particular scene, Alice "is surprised" to see "so many white people" already living in Hawaii (Alice's Visit 22). ${ }^{11}$ Historian Eric Love argues that due to U.S. concerns over the "management" of non-white populations in Hawaii, the “appearance of a 'lily white' citizenry" was "vital to establishing an independent republic, and also a shrewd and necessary precondition for annexation to the United States" (116). To thwart concerns over Hawaii's native and Asian populations, pro-imperialists circulated images of Hawaii as already domesticated by the U.S. The Earles both reaffirm the U.S. domesticity in Hawaii and at the same time represent the absolute racial and cultural difference between white U.S. citizens and native Hawaiians. It is likely the U.S. courts took the "lily white" image of Hawaii into account when deeming Hawaii an "incorporated" territory as opposed to "unincorporated" territory as with Puerto Rico and the Philippines. ${ }^{12}$

In Alice's Visit, Krout works against a primarily masculinist expression of American exceptionalism that was common in turn-of-the-century imperial rhetoric. ${ }^{13}$ Krout deliberately chooses a female child as the central character of the narrative. Young readers learn that Alice is “clever" and adventurous, but still appropriately feminine (Alice's Visit 11). Alice knows "much more about geography than most children of her age" and she likes "nothing better than traveling" (Alice's Visit 7). Krout's choice to make Alice bold, "not timid," reflects Krout's feminist politics and her interest in the emergence of alternative forms of femininity in the U.S. like the New Woman, Bachelor Girl, and Working Girl. As stated, Krout celebrated "the bachelor girl" for her financial stability and professional status. Like adults, children experienced, influenced, and responded to these sociological changes. "American girls," as Gillian Avery notes, were viewed as "more assertive" than British girls. Krout is careful to 
include that Alice travels the rough terrain of Hawaii's mountains "like a man," not on a sidesaddle (Alice's Visits 106). ${ }^{14}$ Krout configures Alice as a New Woman in miniature. Despite Alice's toughness and resolve, she is still configured as an actor, not an agent. Alice isn't the narrator of her experiences; in fact, she doesn't actually speak to readers at all. Instead, the primer uses third-person omniscient narration. This is not an uncommon feature of this particular genre, but nonetheless bespeaks a broader issue regarding the limits of female — and childagency. As a child, Alice is subject to the will of her parents. As a girl, Alice is subject to the rules of polite femininity. So, if exotic-setting children's books were typically, as Singh asserts, "testing grounds for masculinity" and "a great place for a boy...to come of age," then in Alice's Visit, Hawaii is a testing ground for alternative U.S. femininities and a place for girls like Alice to come of age (35).

The contexts of travel and U.S. imperialism allowed Krout to test her own boundaries as they related to gender and women's rights. Krout regularly expressed her own frustrations pertaining to the "woman question" in her newspaper columns. In an article for the Friends' Intelligencer in 1892, Krout lamented that "a woman without a vote is a cipher with no numeral to give it integral value. She stands alone and counts for nothing" ("Women's Vote" 832). She concluded that "education and property qualification count for nothing" ("Women's Vote" 832). In addition to suffrage, Krout expressed frustration with the male-dominated news establishment. In Hawaii and a Revolution, Krout describes the "masculine prudence" of her editors. Her maleeditors, she writes, "did not look kindly" upon her desire to travel to Hawaii in 1893. Undeterred, Krout asserts that "women after all have ten times the daring and resolution of men; and if the generality of them only knew how safe the road and even the uninhabited places of the world, and how purely imaginary the dangers are....there would be a hundreds of explorers like Mrs. 
Bishop and Miss. Kingsley" (Hawaii and a Revolution 39). Even Columbus, Krout explains, was rejected by "kings and courtiers," only to be granted permission finally from "the Castilian Queen, alone, who listened, believed, and pledged her jewels" (Hawaii and a Revolution 39). Krout frames herself as a modern-day (female) Columbus, while also noting that it was a woman — not a man—who "listened" and "believed" in Columbus regarding the splendor of the "new" world. In other words, Krout emphasizes a history where women are a driving force of imperial initiatives and international politics, thus suggesting that the new U.S. empire in the Pacific will provide similar opportunities for turn-of-the-century women to be active historical agents.

Indeed, there is a relationship between expressions of white feminism and U.S. imperialism; empire did provide a space for white women to enact a professional role in international affairs. However, as Newman notes, white women's assertions of gender equality at home and abroad usually hinged on expressions of white racial superiority. Newman writes, "White women's belief in their own race-specific trait of moral superiority permitted them to view other cultures with condescension, if not outright disrespect" (8). As an educational text, the implications of this in Alice's Visit are significant. U.S. schoolchildren, already literate in both popular expressions of gender and race within the United States, are now introduced to a host of evolutionary others including native Hawaiians, Chinese, and Japanese populations. A book like Alice's Visit creates and propagates racialized views of Hawaiians as the quintessential noble savage in desperate need of U.S. oversight and governance.

\section{From" Savagery" to "Civilization": Race, Disease, and Contamination}

In the preface to Alice's Visit, Krout presents young readers with "a study of Hawaiian evolution" (8). Part of the primer's pedagogical aim is to "familiarize children" with the native 
populations in Hawaii (Alice's Visit 7). To this end, Krout includes ethnographic descriptions of Hawaii's non-white populations and promotes a child-like image of Hawaiians who need the parental guidance of the U.S. Students learn that prior to "civilization," Hawaiians "used to fear the darkness, being much afraid of ghosts and evil spirits" (Alice's Visit 43). She continues, "It was long before the missionaries could convince them that such spirits do not exist, and that the nighttime is just as safe as the day" (Alice's Visit 43). Krout uses the image of child-like Hawaiians to make the power structures of U.S. imperialism legible to children readers in the U.S.

Krout categorizes the various races in Hawaii based upon U.S. racial models, which stem from "scientific" discussions of race in fields like "physiology, anthropometry, physiology, and ethnology" (Geiger 55). In Hawaii, the application of these racial types worked to "face the Pacific" for readers in the U.S. and often upheld the legitimacy of empire. In Alice's Visit, children learn the native Hawaiian "type": "dark skin, dark straight hair, black eyes, and good features" (22). The physical descriptions are accompanied by innate character-traits as well. In addition to being "child-like," Alice's Visits reveals that "the race of people born on the islands," are by nature, "fat," “lazy,” and "superstitious" (Alice’s Visit 18, 27, 34, 43). U.S. schoolchildren would have recognized these as negative traits when compared with U.S. ideals of ingenuity, rationality, and modernity. Moreover, Krout describes native Hawaiians as “recently emerging from barbarism," but not yet civilized (citation needed). As Bederman notes, “civilization," as understood by Americans within the context social Darwinism referred to a "stage" in "human racial evolution [and] followed the primitive stages of savagery and barbarism" and functioned, unevenly, "to establish (or challenge) white male hegemony" (23). Like Hamm in the Philippines, Krout uses the rhetoric of civilization and savagery to argue that 
white women could "be partners with white men" in imperialism since they shared "a racial bond that made them partners (perhaps, even equals) in advancing the civilization" (Bederman 124).

Beyond the native Hawaiian population, Krout considers other "races" in Hawaii including Chinese and Japanese residents. Krout's discussion of the Chinese population of Hawaii contains overtones of "the yellow peril" - the perceived threat of Chinese immigrants in the United States in the late-nineteenth and early twentieth centuries. ${ }^{15}$ Throughout Alice's Visit, both Japanese and Chinese residents are associated with criminality, labor, and contagion.

During her trip to Hilo, Alice observes Japanese sugar cane workers where "the sun was hot and the men were covered in dust" (Alice's Visit 61). Alice encounters the Chinese ship-workers who are "queer in custom and appearance" (Alice's Visit 63). When not associated with labor, both Japanese and Chinese populations on the Islands are linked to discourses of criminality. When Alice visits a prison (a seemingly strange stop on her tour and an odd addition to a children's book), she is told that all the prisoners "are Chinese or Japanese. There were no white men among them, and only a few Hawaiians" (Alice's Visit 63). Following this description, students can assume that the Chinese and Japanese are the "deviant" races on the island, which further justifies the perceived threat of yellow peril at home in the United States. Hawaiians, depicted as less threatening noble savages, are still a threat to U.S. white sensibilities. According to these descriptions, it is the white population on the islands that maintains social order and discipline over other helpless and criminalized human races.

Krout's negative descriptions of Hawaii's Asian populations are significant for another reason related to, but beyond the threat of "yellow peril." Love notes that as annexationists attempted to convince the U.S. government to annex Hawaii by framing their plea as "an epochal conflict between two races" (135). As noted, annexationists promoted the "whiteness" of the 
Islands, but also argued that if the U.S. didn't assert official ownership over the Islands, then the white U.S. citizens already living in Hawaii would be overrun by "creeping Asian hordes" (Love 135). Annexationists argued that Hawaii was at a crucial historical tipping point-it would either join the ranks of civilization as a "white" Christian nation, or it would slip back into Asian savagery. The Hawaiian branch of the Sons of the American Revolution declared in an address that if the U.S. didn't take action in Hawaii, then the Japanese would: "Hawaiian markets would be filled with Japanese products, its industries carried on by Japanese planters and manufacturers, and its ports with ships carrying the victorious flag of the Rising Sun" (qtd. in Love 137). The provisional government claimed that they could "hold back the Asians," but they needed the official assistance and endorsement of the U.S. government. While Krout's primer does not address the details of the active anti-Asian argument in Hawaii, her presentation of both Chinese and Japanese populations nonetheless suggests that they would be "unfit" rulers over Hawaii.

Children also learn of the economic benefits of annexing Hawaii through race-based division of labor (the white supervision of non-white laborer). Alice learns that "nearly all the useful plants...were brought to the islands by white men" (Alice's Visit 49). Krout asserts that sugarcane was not properly cultivated by native Hawaiians, but now with native labor and white overseers, Alice learns that "Hawaii yields more sugar than that grown in our Southern states" (84). The "cultivation" of land in Hawaii reversed traditional Hawaiian notions of communal land ownership in favor of (mostly white owned) private property. Wealthy white planters attempted to control "massive numbers of laborers," mostly Chinese and Japanese laborers, through systems that amounted to indentured servitude (McGowan 180). However, Alice's Visit presents Japanese sugar workers as "happy and contented" (89). The primer effaces the brutal 
reality of agribusiness in Hawaii that "immersed workers in a cycle of debt" in favor of highlighting the vast economic potential of Hawaiian exports like sugar, pineapple, kona coffee, guavas, wheat, and corn for U.S. markets—all cultivated by non-white laborers on the Islands (McGowan 180). ${ }^{16}$

Krout's attempt to define and separate "races" in Hawaii is continued and enhanced through her lengthy discussions of disease and contagion. Krout's presents Hawaiians as both vulnerable to and carriers of disease. Krout presents leprosy as a racialized disease that haunts the periphery (literally and figuratively) of an otherwise civilized and properly domesticated territory of the United States. On one hand, Alice learns that the quarantine station she encounters in Honolulu Harbor is meant to protect Hawaiians from disease infiltrating the Islands. On the other hand, prior to reaching Honolulu Harbor, Alice learns that "upon this island many poor people are confined who are ill with a terrible disease, called leprosy" (17). Hawaiians are both vulnerable to disease and in need of U.S. protection, but, at the same time, carriers of disease in need of quarantine. Leprosy, as Alice learns, can never be cured and is highly contagious. The colonial management of leprosy (the decision to deport lepers to Molokai), and Krout's treatment of it in Alice's Visit, are instructive regarding the U.S. biopolitical management of the islands. In Stoler's work on imperialism, the intimate, and biopower, she argues that "the micromanagement of the individual and the macrosurveillance of the body politic" helps maintain colonial control over the colonized. This control is exemplified in the assignment of diseased bodies to a leper settlement - away from the Americanized, semisanitary space of Honolulu.

Krout makes clear that "Alice did not visit Molokai, the island set apart for the poor lepers" (Alice's Visit 156). Visitors must secure a "permit from the government physicians" 
before traveling to the island. Krout explains that the plan of isolating lepers, which may at first seem "hard and cruel," was "in the end, kind and humane" (Alice's Visit 157). In the primer, Krout asserts that Hawaiians were incapable of controlling the spread of this disease: "The Hawaiians themselves never shunned the lepers. They were not repelled by their drawn of misshapen features, but ate of the same calabash" (Alice's Visit 157). Therefore, "the disease could not be controlled" (Alice's Visit 157). Foreign governments responded by "dividing" the islands into districts, zones of contamination and sanitation, and identifying diseased bodies through physical examination. Historian Michelle Moran elucidates the relationship between the management of leprosy and U.S. governance in Hawaii: "U.S. encounters with places where leprosy was widespread in this era...raised fears of its contagion and prompted the development of institutions and policies to contain what was increasingly viewed as a foreign threat encroaching on the national body" (3). Therefore, Molokai remains strictly off limits to Alice and her family. The specter of foreign disease mustn't reach the sacred domestic idol of the American family, or worse, the American child.

\section{White Women and Hawaiian Queens: The Woman Question in Hawaii}

As is apparent by now, Krout's personal gender and racial politics informed Alice's Visit to the Hawaiian Islands. Her racialized descriptions of Hawaiians, created expressly for U.S. schoolchildren, reflected and contributed to turn-of-the-century evolutionary discourses of race and civilization. As an active "bachelor girl" and suffragist, Krout emphasizes the role of women in the "civilization" of Hawaii. Krout views Hawaii as somewhere between "barbarism" and "civilization" on the social evolutionary ladder. The people of Hawaii, based upon their racial status, are also somewhere within this transitional phase. In the preface to Alice's Visit, Krout explains that the primer doubles as a "study in Hawaiian evolution" that alludes to Hawaii's 
barbarous past, semi-savage present, and civilized future (only accomplished through affiliation with the U.S.

Krout argues on "behalf" of native women, claiming that pre-contact Hawaii was a space inherently cruel to women due to its savage patriarchy, thus stunting Hawaiian women's development into appropriate mothers. Krout depicts Hawaiian queens, depending on her commitment to U.S. involvement in Hawaii, as either "exceptional specimens of their race and gender" (like Queen Emma) or as evidence of the continuation of Hawaiian barbarity (as is the case with Liliuokalani who strongly opposed U.S. annexation). Each of these representations of Hawaiian women, as both commoners and Queens, are filtered through Krout's own belief in her "race specific moral superiority," which makes it possible for her to overlook "the ways in which white culture was implicated in systems of oppression that governed the lives" of women (Newman 8). This becomes clear as Krout provides what amounts to a pseudo-hagiography of white missionary women as "civilizing” forces in pre-annexation Hawaii. Krout intends to advocate of behalf of her Hawaiian sisters, but ultimately her commitment to white racial and cultural superiority remains intact.

In Alice's Visit, school children learn that in pre-missionary Hawaii native women were treated very "cruelly" by native men. The primer reports that "under the old chiefs...the lot of average Hawaiian women was often one of great misery," despite their inherent "gentleness and grace" (131). In the "primitive days," women were restricted from temples and "men and women never ate at the same table" (Alice's Visit 47). "Parents loved their sons far better than their daughters," Alice learns (47). The primer continues, if a "boy was five years old, if he was of high rank, he was allowed to eat pork and bananas, and thereafter never again sat at the table with his mother and sister" (47). The depiction of mistreated Hawaiian women and girls stands in 
stark contrast to Alice, who is clearly doted on and adored by her parents. Moreover, Krout highlighted gender-based cruelty against Hawaiian women as an extension of her own arguments toward gender equality in the U.S. The "Hawaiian example" depicts a culture wherein patriarchy was permitted to exert full, seemingly uncontested, dominance. The results, if you follow the logic of the primer, were disastrous for native Hawaiian women and girls.

Krout presents a narrative of Hawaiian history wherein native men exerted their "cruel authority" over native women, resulting in native women who are "stunted" in terms of developing a proper (appropriately white and Western) domesticity. Alice's Visit makes this point clear as it explains patterns of infanticide, which demonstrate the extent to which Hawaiian women make bad-even murderous - mothers. Alice's Visit posits that the act of infanticide was a common part of Hawaiian culture prior to the arrival of the missionaries. "Before they were taught better by the missionaries," Krout writes, Hawaiian women "used to bury their dead near the door or under the floor of their huts. Mothers would often put their children to death as soon as they were born" (Alice's Visit 38). In her article "The Women of Hawaii," Krout provides an even more detailed description of the "barbarous practice": "Infanticide was a common crime, which was encouraged, rather than punished. One woman confessed that she had killed eight of her children and buried them under the floor of her hut" (419). In Alice's Visit, no reason is provided for this practice, but in "The Women of Hawaii" Krout explains that "the excuse offered for the prevalence of infanticide was that the islands were small, and even with equitable division of the land for taro patches...there was always danger of famine" (419). Regardless of the rationale, the act of infanticide would be especially disturbing to white school-age children and would enhance the already unflattering portrayal of native Hawaiians and non-Anglo-Saxon cultures. Children could then add Hawaiians (and the Chinese and Japanese) to "the long list of 
ethnic minorities victimized through cultural stereotyping found often in children's books" (Howes 68). Krout cites the practice of infanticide as proof of the necessity of missionary engagement in Hawaii. She presents native Hawaiian women as lacking proper domesticity and failing in their role as mother. Even though Krout and other white feminists critiqued "the cult of domesticity as too restrictive and oppressive when applied to themselves," many offered a “defense of domesticity as necessary for the advancement of primitive women" (Newman 8). In other words, learning to be a good wife and mother (appropriately feminine and domestic) is an important point on the path from barbarism to civilization. One must pass this point, as Krout felt she and other white feminists had, before they can achieve "civilized status" or full political autonomy.

At the same time, white feminists indeed drew on their "Hawaiian sisters" when it was convenient for the advancement of white women's rights in the U.S. A primary example of this rhetoric appeared in the NAWSA's 1899 "Hawaiian Appeal," a petition to Congress that demanded suffrage for all women in Hawaii (both U.S. and native-born). ${ }^{17}$ The Appeal requested that "in the qualifications for voters in the proposed constitution for the new Territory of Hawaii, the word 'male' be omitted" (20). It continued, "The declared intention of the United States in annexing the Hawaiian Islands is to give them the benefits of the most advanced civilization, and it is a truism that the progress of civilization in every country in measured by the approach of women toward the ideal of equal rights with men" (20). The Appeal further argued that Hawaiians were in the process of moving from the "physical plane" of existence, wherein native women fended for themselves, and where "her failure or success depends wholly on her own strength," to an "intellectual place" of existence, which was governed by law-laws that would, according to the Appeal, "offer women emerging from barbarism the ball and chain of a sex 
disqualification while we held out to men the crown of self-government" (20). The Appeal was rejected by Congress, but nonetheless demonstrates white feminists' rhetorical strategy of "difference and doubling." According to Mary Schriber, "difference and doubling provide two textual attitudes in the constitution of the female other: ethnographic detachment and a nervous psychological attachment expressed in erratic oscillations between empathy and compassion, one the one hand, and arrogance and disdain on the other" (82). Additionally, Alice's Visit and "The Women of Hawaii," along with the Hawaiian Appeal, contribute to what Chandra Talpade Mohanty terms the discursive "production of the "Third World Woman"” by white western feminists (citation?). Krout compares the monolithic oppressed "Hawaiian woman" with "pioneer" missionary women for instructional purposes to further advance her argument for white women's rights in the U.S.

In addition to its general discussion of "native Hawaiian women," Alice 's Visit presents detailed biographies of individual white missionary women. In Alice's Visit, missionary women are a civilizing and domesticating force in Hawaii. Krout reports that missionary women taught native Hawaiian women proper civility and domesticity. Missionary women taught native women to "sew" and "cook," and, importantly, proper methods of child-rearing (Alice's Visit 140). Krout concludes that missionary women in Hawaii were much like "pioneers," which harkens back to U.S. myths of Western settlement, but also suggest the ability, desire, and fortitude of U.S. women missionaries working toward "civilizing” Hawaii. For example, Krout highlights the Boston-born missionary Mrs. Laura Fish Judd, the wife of medical missionary Dr. Judd. Mrs. Judd "had to cook and mend and do much hard work," which Alice learns from her mother (Alice's Visit 151). Moreover, Alice learns that Mrs. Judd took over responsibility for the 
education and general well-being of native women in Hawaii. It is clear that Krout wishes to show the tradition of women travelers as a civilizing and domesticating forces of U.S. culture. In Alice's Visit, Krout also provides sketches of Hawaiian queens who are depicted as either "exceptional" specimens of their race or as evidence of continued Hawaiian barbarism. Only those queens who accepted U.S. missionary and military intervention in Hawaiian culture are given flattering portrayals. This is most obvious in the lesson on "the Nobel-hearted woman" Chief Kapiolani. Mrs. Earle explains to Alice that Chief Kapiolani was supportive of U.S. missionaries and "became a Christian" (Alice's Visit 77). Alice learns that Kapiolani faced Pele's crater, a sacred space where the goddess Pele was thought to reside. Native Hawaiians believed that "if any one disobeyed [Pele], she would strike him dead" (Alice's Visit 76). Mrs. Earle explains that "missionaries had tried in vain to show the Hawaiians that this idea was false, but the people were still in deadly fear of this spirit" (Alice's Visit 77). Therefore, as the story goes, Kapiolani goes to the volcano to face Pele in an effort to show her fellow Hawaiians that Pele is not a "true god" (Alice's Visit 78). Alice learns that when Kapiolani reached the volcano, onlookers were stunned because she "neither vanished from their sight, nor was she stricken to the ground by the angry spirit" (Alice's Visit 78). As a result, Kapiolani convinces her people that "their thoughts of Pele were but illusions" (Alice's Visit 79). Krout praises Kapiolani in Alice's Visit for her purported participation in the erosion of native beliefs, traditions, and customs.

Alice's Visit also includes a discussion of Queen Liliuokalani, which stands in contrast to the primer's treatment of Queen Kapiolani. Krout casts Liliuokalani, the reigning queen disposed and imprisoned following the 1893 U.S. overthrow of the Hawaiian monarchy, as a villain and criminal in Alice's Visit. Krout combines her critiques of Liliuokalani with a pro-annexation historiography. Krout notes that "at this time many people thought it would be a good plan to ask 
the United States to govern the Islands; but it took time to consider what would be best for both countries, and it was not before the summer of 1898 that the Hawaiian Islands were annexed to the United States" (Alice's Visit 176). Krout continues by explaining that "the people in Hawaii established a republican form of government and chose a president, Mr. Sanford B. Dole, who...white people and Hawaiians knew they could trust" (Alice's Visit 177). Krout celebrates Dole's governance over the islands and presents the passive acceptance (even support) for U.S. leadership among native Hawaiians. Recent revisionist historiographies of Hawaiian-U.S. relations, like those by Silva and Kēhaulani Kauanui, demonstrate that U.S. annexation was not merely accepted by native Hawaiians. In fact, there were mobilized resistance movements, demonstrated by ample evidence in Hawaiian-language newspapers and magazines, along with an anti-annexation petition that was signed by nearly ninety-five percent of native Hawaiians (Silva 5).

In Krout's version of events, which reflects the dominant pro-annexation narrative, Liliuokalani is cast as a criminal because she did "not wish the Hawaiian Islands to be governed by the United States" (Alice's Visit 177). Krout presents Dole as a symbol of U.S. benevolence and order while she presents Queen Liliuokalani as selfishly obsessed with "royal power" (Alice's Visit 175). Liliuokalani was “jealous of the power of the white men, and thought if she could but get rid of them she could make new laws to suit herself" (Alice's Visit 175). The primer continues to explain that Liliuokalani refused to acknowledge that "the white men understood better than she how to govern" (Alice 's Visit 175). Liliuokalani's deviance is further describe in Alice's Visit: "When she lived at the Washington Villa, she held secret meetings at her house and brought guns and swords, power and shot, which were buried in pits upon her lawn" (Alice's Visit 177). She planned to "arm Hawaiian soldiers and fight in the streets, until the 
people who opposed her were conquered or killed" (Alice's Visit 178). Krout posits that Liliuokalani simply refused to accept the purportedly infallible U.S. claim to Hawaii. The white men who Liliuokalani wished to "conquer," Krout explains, "had been born there [in Hawaii]...and that it was their country just as much as her own" (Alice's Visit 178). Eventually, after her plans are foiled, Liliuokalani is "taken back to the palace, not however as a queen, but as prisoner" (Alice's Visit 178).

These opposing depictions of two Hawaiian queens send a powerful message to U.S. school children: only those queens who supported U.S. annexation and accepted Christianity are "noble" and strong. Those who did not, like Liliuokalani, are selfish, power hungry desperados. Many native Hawaiians, then and presently, viewed Liliuokalani as a national hero for her fight against U.S. annexation. Krout's emphasis on annexation overrides an opportunity to provide more sympathetic renderings of female power, noble or otherwise. Hawaiian queens are positive examples of female strength if, and only if, they accept U.S. power indisputably. The narrative version of events presented in Alice's Visit, as Silva points out, continues to dominate popular understandings of Hawaii-U.S. relations. Stories like Alice's Visit, which present Liliuokalani as a rouge element with a few equally deviant coconspirators, perpetuates the untrue assertion that the vast majority of Hawaiians accepted (even welcomed) U.S. annexation passively and without protest.

U.S. schoolchildren learn much more about Hawaii than its geography in Alice's Visit; they learn that as Americans they share ownership over the islands of Hawaii, its inhabitants, and its natural resources. Additionally, they learn that annexation of Hawaii was the only right and just course of action when, in reality, there were active anti-imperialism movements in the U.S. and Hawaii that vocally opposed annexing Hawaii (and other locations including the Philippines 
and Puerto Rico). While U.S. anti-annexation arguments aren't even acknowledged in Alice's Visit, native resistance movements are reduced to drunken plots and criminal savagery. To tell the "other side" of Hawaii's annexation, territorialization, and eventual U.S. statehood, would amount to admitting to U.S. schoolchildren that Hawaii was in fact a "stolen nation" (Kauanui 85). As the twentieth century progressed, U.S. imperialism in Hawaii manifested itself economically (through imports and exports), politically (through statehood), and culturally (in phenomena like the "hula circuits" of the 1950s). ${ }^{18}$ In the preface to Alice's Visit, Krout claims to understand "the consequences of filling the impressionable minds of children with painful images and facts that they cannot reconcile with justice" (7). This statement begs the question: justice for whom? Two years after the publication of Alice's Visit, Krout turned toward another foreign space with a second geography primer titled Two Girls in China. And with this, Krout continued to contribute to the imperial imaginations of U.S. school children. 
Bebell 103

\section{Chapter Four}

“A Free American Girl”: Gender, Race, and Economic Empire in

Nellie Bly's Six Months in Mexico

\section{Introduction}

On May 5th 2015, the ubiquitous Google banner celebrated the 151st birthday of turn-ofthe-century "newspaper lady" and activist Nellie Bly. ${ }^{1}$ The doodle, which commemorates holidays, anniversaries, historical figures, artists, and pioneers, featured a sepia-toned animation of a cartoonish looking Bly. For many viewers in the U.S., Bly was unfamiliar face, despite her popularity at the turn into the twentieth century. During Bly's lifetime, her crowning achievement was her 1889 trip around the world, which was sponsored by Joseph Pulitzer's New York World, wherein Bly broke the record set by Jules Verne's protagonist in the fictional adventure Around the World in Eighty Days (1873). After her highly publicized success, Bly returned to the United States as a cultural icon praised (and reviled) by the American public for her embodiment of female accomplishment and her pioneering attitude. Consequently, the U.S. market was flooded with Nellie Bly swag_-including books, costumes, board games, luggage, and toys that capitalized on Bly's visibility within American popular culture. Yet, as is the case with so many notable turn-of-the-century women journalists, Bly is now almost lost to popular historical memory.

As with popular memory, Nellie Bly is also mostly absent from scholarship in the fields of journalism, literature, and history-despite her prolific career. ${ }^{2}$ During the last decades of the nineteenth century, Bly was well-known for her muckraking journalism. In addition to her 1889 Around the World in Seventy-Two Days, Bly published Ten Days in the Madhouse, an exposé wherein Bly had herself committed to a New York City women's mental hospital to uncover 
inhumane treatment of patients. ${ }^{3}$ Around the World was not Bly's first experience with foreign travel. Three years earlier in 1886, while employed at the Pittsburgh Dispatch, Bly traveled to Mexico as a foreign correspondent. She sent articles from Mexico to the Dispatch during her five month trip, but it wasn't until 1889 that Six Months in Mexico was published for a general audience. In addition to these book-length works, which were all compiled from series of newspaper articles, Bly was a prolific contributor to several well-known U.S. newspapers, including The New York World, New York Evening Journal, and Chicago Times-Herald. As a whole, Bly focused on exposing social ills and injustices against those who she felt were oppressed by unfair social and political structures, especially U.S. women.

Born Elizabeth Cochrane near Pittsburgh, Pennsylvania in 1864, Bly began her journalism career at the Pittsburgh Dispatch and wrote extensively on social issues plaguing U.S. society. ${ }^{4}$ Her earliest publication was a fiery letter in response to an article by columnist Erasmus Wilson that insisted the only "proper" role for women was that of housewife. ${ }^{5}$ He even jested that the U.S. might follow China's example by killing their girl babies. Twenty years old at this time, Bly penned a response signed by "Lonely Orphan Girl” vehemently arguing against Wilson's anti-woman logic. In what became titled "The Girl Puzzle," Bly imagined a better future for women and argued for their right to education and professional work. In her ideal society, women would be "receiving men's wages, she would feel independent; she could support herself. No more pinching and starving, no more hard work for little pay" ("Girl Puzzle" 7). "In short," Bly concluded, "she would be a woman and would not be half as liable to forget the duty she owed to her own true womanhood as one pinched by poverty and without means of support” (“Girl Puzzle” 7). After Bly’s public tiff with Wilson, George Madden, managing 
Bebell 105

editor at the Pittsburgh Dispatch, offered her a regular column that focused on the "woman's sphere."

Bly responded strongly to Wilson in part because of her own personal experiences growing up - experiences that would continue to inform her work throughout her lifetime. By her own account, Bly's early childhood was idyllic. Her childhood was abruptly interrupted with the unexpected death of her father, which placed a tremendous economic burden upon Bly's mother, Mary Jane. Mary Jane remarried a man, who according to Bly's later recollections, was an abusive alcoholic. Bly testified in the divorce proceedings and saw first-hand the injustices thrust upon women by an unforgiving legal system that privileged men. Though the divorce was granted, Bly's family found themselves in dire financial straits. This experience would prove pivotal in the construction of Bly's feminist and working-class persona. As her career progressed, Bly became practically synonymous with the figure of the New Woman, which rejected the ideology of separate spheres in favor of an independent, educated, and professional woman.

Like many other nineteenth-century women writers, journalists, and public figures, Bly has been largely forgotten in the historical record. In the only academic biography of her life, biographer Brooke Kroeger notes Bly's near invisibility among academic sources despite her national popularity at the turn-of-the-century $(\mathrm{xv}){ }^{7}$ By the last decades of the nineteenth century, Bly was a household name. Caricatures of Bly appeared in newspapers, games, and children's toys. For the American public, Bly was a symbol of a "distinctive modernity" (Ruddick 2). Her trip around the world, which coincided with the U.S.'s growing expansionist ambitions, signaled in a tangible way changes to the socio-political structure of the United States. Her trip, and the "machines of motion" that made travel possible (such as the steamship and railway), reminded 
U.S. observers that the world was a small place (Smith 6). The image of Bly, who traveled in a professional capacity and unchaperoned by a man, challenged rigidly held gender expectations of the time. From this perspective, Bly's travel writing, including Six Months in Mexico, was first and foremost "a political practice" (Schriber 165). Through her travel writing, Bly made herself "heard on national and international issues, including concepts of gender and rules of decency that impinged their daily lives at home and abroad" (Schriber 165). Of all the sociopolitical issues that interested Bly, gender equality remained her primary focus throughout her journalism career. By the late 1890s, she would find herself in the company of Susan B. Anthony and Elizabeth Cady Stanton, both of whom she interviewed while attending and reporting on various suffrage conventions. Ten years earlier, in the late 1880s, Bly had few "formal" connections to the suffrage movement, and was relatively unknown by the public, yet she was already unwavering in her commitment to women's rights.

Bly, a "girl stunt reporter," understood herself as a character within in her stories and almost always wrote from a first-person perspective. ${ }^{8}$ She carefully crafted her persona to present herself as a plucky, independent, and socially conscious New Woman who took up for the underdog — women, the poor, and even animals — at home and abroad. As her career progressed, Bly became synonymous with muckraking and sensational journalism—so much so that she became the object of criticism among other female journalists, including her contemporary, Margherita Arlina Hamm, who publically questioned Bly's "low grade of sensationalism" for its “extravagance" and lack of "truth" (qtd. in Kroeger 206). ${ }^{9}$ Six Months in Mexico is an early glimpse into the future of Bly's career in stunt reporting - a genre that would later make her famous. Throughout Six Months, Bly filters her account of Mexico through personal impressions and promotes her gender status whenever possible (as the only woman on the railcar for 
example) or when she recalls fleeing Mexico under threat of arrest (for openly criticizing Mexican government). Six Months shows Bly's early ability "to turn her personal circumstances into news" (Lutes xvii). Though the dispatches collected in Six Months in Mexico are from Bly's early career, she certainly already understood the power, along with the social and political significance, of a "free American girl" in Mexico (Six Months 263).

Unlike some of her more "polite" contemporaries who traveled with their husbands, Bly traveled as what Jennifer Bernhardt Steadman calls a "ragged-edge traveler" (111). This label describes working-class women who traveled in a professional capacity outside of the borders of the U.S. Steadman notes that the "figure of the ragged-edge female traveler" challenged "middleclass definitions of appropriate femininity" and provided a "counter-example that reinforces middle-class notions of proper womanhood" (111). Bly fits this description well. She didn't have the financial support of her newspaper and, given the family's financial situation, work was a necessity. Bly challenges the definitions of appropriate femininity in her choice to travel unchaperoned and makes her gender status central to her narrative. At one point, she jests that trials faced by solo female travelers are enough to prompt her to "fall into the arms of the first man who mentions to marry me...then I will have someone to look after me" (Six Months 190). Bly's mother responds to this comment with nothing more than a "little doubting smile" (Six Months 190).

Six Months in Mexico is a collection of Nellie Bly's reports to the Pittsburgh Dispatch over a five-month period. As Bly tells it in the opening pages, she was, at age twenty-one, "too impatient to work along at the usual duties assigned to women on newspapers" and so she set out for Mexico reporting that "a free American girl" caused quite a spectacle on the railway (Six Months 189). Bly relates that most of the women on the train had at least "one male escort," but 
she traveled with the company of her mother and "defied the gaze" of the gawking passengers (Six Months 195). While traveling, Bly sent correspondence back to the Pittsburgh Dispatch on a fairly regular basis; these dispatches were published under the feature title "Nellie in Mexico." The articles (which would later become chapters in the book) covered a variety of topics related to the customs, culture, people, and politics of Mexico. Bly begins with her journey by rail to Mexico and her impressions of the border. Once in Mexico, she describes the landscape and geography; city life; customs related to marriage, death, and religion; brief historical anecdotes; and her impressions (and criticisms) of Mexico's political structure. In 1886 only subscribers to the Dispatch in western Pennsylvania would have read her accounts. ${ }^{10}$ However, Bly became a household name following her 1889 trip around the world. Capitalizing on her fame, New York's John W. Lovell and Company collected and published Bly's Mexico stories as Six Months in Mexico. It was then that Bly's impressions of Mexico reached a far wider U.S. reading public.

\section{A "Sister Republic" to the South: U.S. Travel Writing and Mexico}

I join other scholars such as Jason Ruiz and Gilbert González in examining the links between U.S. imperialism and late-nineteenth U.S. travel writing about Mexico. They discuss how travel writing about Mexico assisted in the production of the U.S. imperial imaginary in regards to what was commonly called America's "sister republic." Typically, nineteenth century U.S. travel writing presented Mexico as a viable "sphere of influence" wherein the U.S. could exercise what González terms the "economic conquest" of Mexico with the cooperation of Mexican president Porfirio Diaz and wealthy U.S. capitalists (47). As the recent "transnational turn" in American Studies shows, U.S. empire-building was achieved in more ways than just militaristic force or annexation. Yet Mexico is often left out of academic discussions of U.S. imperialism at the turn into the twentieth century, which instead focus on more conspicuous 
Bebell 109

locations of empire such as Hawaii, the Philippines, or Puerto Rico. Ruiz notes that often "historians consider American aggression against Mexico in the 1840s as a foundational moment in the historiography of U.S. imperialism" but then "tend to shift away from Mexico following the Treaty of Guadalupe Hidalgo and the Gadsden Purchase" (5). ${ }^{11}$ Late-nineteenth and turn-ofthe-century U.S. travel writing demonstrates the extent to which Mexico was viewed by Americans through the lens of imperial fantasy and the extent to which travel discourse was "deeply bound to racialized and sexualized accounts of Mexican bodies" that functioned as sites of knowledge for the production of U.S. empire (Ruiz 4). My goal throughout the remainder of this chapter is to consider the ways in which Bly's representations of Mexico not only function to establish Mexico as a site of U.S. economic conquest, but also how these depictions function within broader discourses of U.S. gender and racial politics in the later years of the nineteenth century.

Not only did U.S. capitalists and businessmen take an economic interest in Mexico in the late nineteenth century, but Mexico was an increasingly popular location for U.S. travel writers, artists, students, anthropologists, and pleasure seekers. There was an especially robust market for travel books about Mexico, which worked in tandem with U.S. economic interests to create a “culture of empire” (González 7). Articles about Mexico appeared in books, magazines, newspapers, and popular journals in the late nineteenth and early twentieth centuries. Booklength works include Two Thousand Miles through the Heart of Mexico (1886), A White Umbrella in Mexico (1895), Mexico of the Twentieth Century (1907), Mexico Today: Social, Religious, and Political Conditions (1913), and The Mexican Problem (1917) (González 47). Articles appeared in venues such as Collier's, Atlantic Monthly, Survey, The Independent, and National Geographic. U.S. women also contributed to this work. The most well-known U.S. 
Bebell 110

woman travel writer in Mexico during this period was Mary Robinson Wright who wrote Mexico (1892) and Picturesque Mexico (1910). Bly knew she wasn't the first female journalist to write about Mexico but hoped she would "be more fortunate than other female correspondents in getting the character of Mexican life" (Six Months 196). González argues that late-nineteenth century U.S. travel writers were nearly unified in their unabashed support for the “Americanization" of Mexico and in their support for Mexico's president Porfirio Diaz, who was extremely open to developing an economic relationship with the United States. But Bly departed from this common narrative and offered a different take on Mexican politics. She supported an economic partnership between the U.S. and Mexico, but waged an anti-Diaz critique. Rather than celebrating Diaz's attitude toward U.S. influence and modernity, as so many other U.S. writers did, Bly instead focused on the human suffering she witnessed in the name of modernity under Diaz's regime.

Although Bly viewed Mexico as a resource for U.S. economic interests, she criticized the Díaz regime for its brutal treatment of women and indigenous people (usually called "peons" in the U.S. press). From this perspective, Bly both supported and subverted conventional discourses of U.S. economic imperialism toward Mexico. Her critique focused on the condition of Mexico's women and children, and she waged a cross-cultural critique of Mexican and U.S. patriarchies in the service of a proto-transnational feminist argument for women's rights. At the same time that Bly finds commonality between U.S. and Mexican women, she nonetheless racializes Mexican and indigenous peoples in ways typical of turn-of-the-century U.S. discourses on Mexican “others.” Her gender politics reveal an unevenness in which U.S. women, indeed oppressed by patriarchy, are nevertheless superior-racially, culturally, and nationally — to Mexican and indigenous women whom Bly's renders as bare life even in her sympathetic account. Moreover, 
Bly is almost myopic in her critique of Díaz, thus effacing U.S. responsibility for what she views as a humanitarian crisis among Mexico’s poor. Bly's Six Months shows readers that an individual can object to an aspect of the imperial agenda (in this case, the support for Díaz) without rejecting the imperial project as a whole. Bly's stance blurs the line between "pro" and "anti" imperialist and suggests the complex dynamics at play in the discursive creation of Mexico for U.S. audiences.

\section{U.S. Economic Relations with Mexico and Bly's Critique of the Porfirio}

Bly supports U.S. cooperation with Diaz for its economic benefits and "modernization" efforts but criticizes Diaz for leaving indigenous Mexicans out of his plan for progress. Bly departs from the mostly popular images of Diaz circulating in the United States. Diaz, as Ruiz notes, "embodied in the American imagination both an idealized colonial leader who could facilitate their economic conquest and, crucially, the mestizo subject whose modernization would ensure the political stability of the nation" (66). Bly critiques the Diaz regime for its mistreatment of the poor, unfair allocation of resources, withholding of voting rights, and the lack of a free press or open political dialogue in Mexico. Ultimately, she argues that Mexico was "a republic in name, being in reality the worse monarchy in existence" (Six Months 291). Bly separates economic and social matters, thus ignoring the ways in which each informed and impacted the other. In other words, Bly neglects to consider how the economic support of the U.S. upheld many of the unfair policies she criticizes. Instead, Bly concludes that Mexico's social problems were the direct result of a corrupt and "tyrannical czar" (Six Months 291).

By the 1880s, the U.S. launched an economic and cultural invasion into Mexico that would lay the groundwork for Mexico's status as an official sphere of U.S. influence. When Bly traveled to Mexico there was already evidence everywhere of U.S. capital and investment - the 
railroads, the mining operations, the roads, and telephones. By the 1880s, one billion dollars of U.S. capital was invested in railroad construction alone (Truett 77). U.S. politicians and industrialists considered Mexico a viable market for overproduced goods, a source of cheap labor, and the home of abundant natural resources. While the U.S. didn't formally colonize Mexico, it made Mexico an "economic satellite," that was "subjected to an overriding economic influence tantamount to colonization" (González 17). This policy purposefully avoided territorial annexation in favor of "an economic domination that served emerging corporate interests" in the U.S. (González 17). The U.S. State Department offered incentives to U.S. capitalists, such as government-backed loans, and actively encouraged U.S. business interests in Mexico. The enactment of these initiatives would have proven impossible without the active support of the Mexican government under the direction of President Diaz and an elite class of Mexican landowners whose interests Diaz represented. His presidency, known as the Porfirio, lasted over thirty years (1876-1911). During this time, Diaz encouraged an "open door policy” toward U.S. capital through tax waivers, cheap property costs, cheap labor, and other incentives. By the end of the nineteenth century, U.S. businesses established footholds in the areas of railroad construction, mining, oil, and agribusiness, among others (Foley 40).

The influx of U.S. capital transformed Mexico’s economy, but did so with disastrous social consequences. Diaz, who was of indigenous roots, wished to remake Mexico as a "modern" nation with the assistance of wealthy advisors called cientificos, an elite Mexican upper-class, and U.S. monetary investment. Diaz maintained power by terrorizing the poor and executing tight control over local governments. The poor were stripped of voting rights and communal lands were confiscated and transformed into "large holdings (haciendas) where a small class of wealthy land owners held a large peasant workforce in semi-feudal bondage 
through debt personage" (Foley 44). Diaz's modernization plans included a feudal-landowning system, which impoverished Mexico's indigenous populations through an endless cycle of generational debt. Diaz sold the confiscated land, at dirt cheap prices, to European and U.S. investors to make way for railroad construction, oil fields, and copper mines. The result was the emergence of a colonial pattern of labor. As González explains, "new social relations introduced into Mexico by foreign capital bore a striking resemblance to the colonial pattern whereby foreigners design, administer, and enrich themselves from the country's important economic undertakings with the assistance of local elites" (45). In other words, it was mostly indigenous Mexicans who performed the labor of U.S. economic conquest.

Bly supports the U.S. economic intervention in Mexico as a way of creating a new frontier for American expansion. Along these lines, she calls Mexico "a new California” (Six Months 224). She boasts that "Mexico makes many bright promises for the future. As a winter resort, as a summer resort, a city for men to accumulate fortunes, a paradise for students, for artists; a rich field for the hunter of the curious, the beautiful, the rare" (Six Months 310). This "bright future," Bly notes, "is not far distant" (Six Months 310). Thus, even before Frederick Jackson Turner announced the "official" closing of the western frontier in 1893, Bly sees Mexico as a promising future frontier of U.S. expansion and development. ${ }^{12}$

Even though Bly supports U.S. efforts to "modernize" Mexico, she also expresses a sense of loss over changes to indigenous Mexican culture. Like other U.S. travel writers, pleasure seekers, and businessmen, Bly finds scopic pleasure in the perceived backwardness of Mexico's indigenous population. She reports that "the poor Indian woman is replacing the fascinating rebozo with a horrid shawl; the Indian man is changing sandals for torturing shoes and cool linen pantaloons and serape for American pantaloons and coats" (Six Months 224). "Civilization," Bly 
writes, and "her twin sister style have caught them in their grasp" (Six Months 224). Bly supports Mexico's "bright future," but she expresses ambivalence (if not distaste) toward changes in the appearance of Indians. In U.S. travel narratives, Mexico's “living Indians, positioned among ancient ruins, served as a primary site of contact that showed Americans how to desire Mexico" (Ruiz 21). Here, Bly desires both a modernized and ancient Mexico—a Mexico that resembles a new California while simultaneously maintaining its primitive charm.

While Bly seems to support an economic relationship between Mexico and the United States, she critiques the Diaz regime for its social injustices. Specifically, Bly finds reprehensible the Porfirio's mistreatment of the poor. Bly summarizes her critique in the following passage: Very few people outside of the Republic of Mexico have the least conception of how government is run here. The inhabitants of Mexico - at least as it is estimated-number 10,000,000 souls, 8,000,000 being Indians, uneducated and very poor. This large majority has no voice in any matter, whatever, so the government is constructed by the smaller, but so-called better class. (Six Months 291)

Bly asserts that this sort of social inequity represents the tyrannical actions of a "czar" who purports to run a democratic republic. In the spirit of investigative reporting, Bly presents this information to readers as "facts which... have never reached the public prints" (Six Months 291). Indeed U.S. critiques of Diaz did exist; however, Bly was definitely in the minority with her vocal anti-Diaz criticisms. The vast majority of U.S. travel writers praised Diaz for his commitment to modernizing Mexico in the image of the United States. 
Bebell 115

\section{"Sisters in the States": Nellie Bly's Transnational Critique of Patriarchy}

Bly wages a critique of the Mexican government, under the direction of Diaz, for its mistreatment of the poor. She focuses on the lives (and deaths) of peons, with an emphasis on the experiences of indigenous women and children. In doing so, Bly creates a cross-cultural comparison of politically-sanctioned patriarchies wherein she advocates on behalf of indigenous women and children, thus using the "Mexico example" to highlight the inequities of U.S. gender politics at home. Bly looks to intimate spaces, such as marriage and reproduction, to highlight the oppression of Mexico's poor women and children. She laments that Mexican children are apt to die before maturity due to disease-filled streets, lack of nutrition, and the absence of proper parenting.

While Bly is sympathetic toward the domestic constraints placed upon Mexico's women, she nonetheless racializes Mexican women and renders them bare life. In doing so, Bly reveals the unevenness in which U.S. women, though victims of patriarchy, maintained racial superiority over non-white women. Bly's focus on her Mexican "sisters" reveals the limits of universalizing white feminism, which has been effectively critiqued by Chandra Mohanty, Trinh T. Minh-ha, Norma Alarcōn, and other postcolonial feminist scholars (Six Months 229). Bly's identification with and against Mexican women suggests a problem inherent in discourses of (proto)transnational feminism. Bly presents Mexican women without individualization, thereby suggesting that all Mexican women experience patriarchy in the same way-and in a way that is similar to (perhaps worse) than U.S. women. Bly reveals the "dark lives" of Mexico's women and children through the language of otherness and difference. As a result, Bly promotes her own cultural, moral, and racial superiority as an "American girl," which lends itself to "the dominant culture's compartmentalized ordering of individual, family, and nation as colonizing, capitalist 
strategies" (Pérez 26). To this end, Bly looks to the intimate areas of the domestic lives of indigenous and Mexican women in the service of U.S. feminism, which results in creating "clear distinctions between native and foreigner, domestic and international, America and América" (Alemán 77). In other words, though Bly wishes to find commonality in the experiences of Mexican women and U.S. women, she ultimately reproduces the very power structures she wishes to subvert.

In a section titled "Cupid's Work in Sunnyland," Bly critiques Mexican courtship and marriage practices for the constraints they place on women. She states that she wants to show Mexican women's "sisters in the States" a comparison between "the system here with home customs" (Six Months 229). She describes Mexican courtship (among the middle- and upperclasses) as a process that is quick and unforgiving. Skeptical of the uneven deployment of marriage laws in the U.S. following the divorce of her mother, Bly sarcastically announces: "Love! That wonderful something - the source of bliss, the cause of maddened anguish! Love and marriage form the basis of every plot, play, comedy, tragedy, story, and, let it be whispered, swell the lawyer's purse with breach of promise and divorce case fees" (Six Months 229). Bly focuses on the "tragedy" of marriage practices that subjugate women in Mexico, but her account certainly reflects her ideas about gender politics in the U.S. as well. To speak of "sisters in the States" suggests that Bly considers the experiences of women from different cultures overwhelmingly similar. In this way, she indicts both U.S. and Mexican patriarchies in a general critique of patriarchal marriage practices.

For Bly, Mexican marriage practices, and to a lesser extent U.S. marriage practices, reflect cultural "barbarism" and female "slavery." Bly explains that Mexican women "have absolutely nothing" and are, perhaps, worse off than "their sisters in the States" when it comes to 
the social arrangement of marriage (Six Months 231). She explains a typical marriage in Mexico as a legal transaction that disenfranchises women who do not have the freedom to choose their partner, writing, "If a man gets impatient and feels like he is rejected he can go to a public official... and agreements are drawn up" to arrange the marriage — with or without the woman's consent - and to determine "how much will be the daughter's portion at the death of her parents" (Six Months 231). After a lengthy description of a Mexican wedding, Bly notes that immediately after the ceremony, "The husband claims his bride, and with jealously does her guard her" (Six Months 232). Once married, a Mexican woman's life is “spent in seclusion," and she is left with "a desperately jealous" husband who prohibits his wife from "being in the company of another man" or having a public life outside the home (Six Months 232). For this reason, Mexican women cannot work or find professions thus leaving them financially reliant upon their husbands or else destitute. And, if their husbands tire of them, Bly reveals, they are left with nothing. To emphasize this issue, Bly relates that Diaz's right-hand official, Manuel Gonzales, separated from his wife. After the separation, Bly reports, Gonzales "lives like a king" while his wife lives “in abject poverty, and, like all Mexican women, with the door to the way of gaining an honest livelihood barred against her because of her sex" (Six Months 292). The Gonzales example shows that the mistreatment of women is not solely a problem within the lower classes of Mexican society. Rather, it is a practice sanctioned by and in the interest of Mexico's patriarchal elite.

Bly equates the social seclusion of Mexican women with physical and social death. She argues that Mexican women are never free from Mexican patriarchy. To this point, Bly highlights a particularly ghoulish cultural practice. She reveals that in Mexico "when death takes one [a wife] away" the bones remain "buried for ten years" (Six Months 232). At the end of that 
time, the wife's bones are exhumed by the husband and "placed in a jar and taken home" (Six Months 232). Bly recounts a Mexican man who shows her an unassuming jar that she learns contains "his first wife, even her fingernails" (Six Months 232). Bly considers this a "dismal ornament and memento," which is akin to desecrating human remains. Yet it serves a powerful symbolic purpose; it suggests to Bly that Mexican women are kept in seclusion and confinement under the complete control of their husbands. From this episode, Bly gleans that Mexican women are always experiencing a type of social death—or at least a life that isn't "really worth living" (Six Months 221).

Bly uses these examples of the mistreatment of Mexican women to further her critique of marriage and divorce laws in the United States. As stated, the divorce of Bly's mother from an allegedly abusive man shaped Bly's attitudes toward women's marriage rights and economic independence. As a newspaper lady, Bly advocated for laws that would legally and financially protect women in marriage and divorce. But more than that, Bly advocated for more education and professional opportunities for women as the only way to guarantee independence from men. She argued that women should have access to professions beyond that of factory worker, clerk, teacher, or maid (which, Bly explains, do not provide a real living). In her first published article, “The Girl Puzzle," Bly asks readers why women cannot work in the same fields as men, "as merchant travelers" or as "Pullman palace car" conductors ("Girl Puzzle" 7). She then calls to "believers in women's rights" (most likely referring to suffragists) and suggests they "forgo their lecturing and writing and go to work; more work and less talk" (“Girl Puzzle" 7). While Bly supported the suffrage movement, it is obvious here that she considered their approachlecturing and writing about the "woman problem"—-stale and somewhat ineffective. In 1896, a little over ten years after she wrote "The Girl Puzzle" and Six Months in Mexico, Bly reported on 
Bebell 119

the National Woman Suffrage Convention in Washington D.C. (where she scored interviews with both Susan B. Anthony and Elizabeth Cady Stanton for The World). Bly still felt as though suffragists talked a good game but had yet to see real results from their efforts.

\section{The “Dark Lives" of Mexico's Poor: Aesthetic Pity and Bly's Racialization of Mexicans}

Although Bly offers her sympathy and support to Mexican women, she uses racialized descriptions of Mexicans throughout Six Months thereby maintaining the uneven racial dynamics of U.S-Mexico relations. Specifically, Bly uses the language of "aesthetic pity" (Spurr 53). Aesthetic pity, as Richard Spurr explains, refers to the "aesthetic representation of human suffering that is always once removed from economic and social realities" (53). The language of aesthetic pity "treats the third world as material for sentimental human interest of melodramatic entertainment" (Spurr 54). In one indicative scene, Bly describes "the lowest class of Mexicans" who are "homeless" (Six Months 199). They "huddle in the shadows...devouring what food they scraped up, consisting of refused meats" (Six Months 199). Bly's descriptions of peons' abject poverty, even bare life status, is squarely situated within her broader critique of the Mexican government, but it still remains removed from the historical and political reality of U.S. economic imperialism, which certainly contributed to the condition of Mexico's working class. If one takes the "home" as the nation in miniature, then the lack of a home (in a traditional sense) suggests a challenge to Mexican nationhood itself, thereby creating a need for U.S. intervention. Further, travel writing like Bly's discursively produces the "Mexican other" —-sometimes as an object of pity and other times as a threat to U.S. imperial interests in Mexico (or even as both). These depictions continue to dictate the direction of U.S.-Mexican relations, particularly regarding Mexican immigration, which was increasing in numbers at the turn in to the twentieth 
Bebell 120

century. These racialized treatments often involve issues of disease and hygiene, which she explores through discussion of the domestic arrangements of peons.

These discussions serve the imperial function of biopolitical surveillance. As Foucault makes clear, discourses of disease are crucial in modern population control: "[T]he old power of death that symbolized the sovereign power was now carefully supplanted by the administration of bodies and the calculated management of life" (Lectures 138). Within the colonial context, as Ann Laura Stoler and Laura Briggs observe, race and disease were linked in discussions regarding the management of colonial subjects and their "fitness" for self-rule. Six Months shows how biopolitical surveillance operated in U.S. "spheres of influence"-where inequities in power relations were maintained through economic subordination as opposed to territorial annexation. The proximity of Mexico to the U.S. caused concern among Americans regarding foreign disease, which many perceived as a legitimate threat to the U.S. public. This anxiety was only exacerbated by the influx of Mexican migrants and laborers who were entering the U.S. in record numbers as the U.S. continued its "economic invasion" of Mexico.

Bly does not offer a full racial taxonomy of Mexicans as did Hamm in the Philippines or Krout in Hawaii. Rather, she tells readers that there are three general "races" of people living in Mexico: "Indians," "real Mexicans," and Euro-Americans (Six Months 289). Bly directs most of her disdain toward "real Mexicans," who, she explains, are "a mixture of several nationalities, and have a great greed for cash, and think the Americano, Yankee, or gringo, was sent here to be robbed” (Six Months 289). By contrast, she presents Indians as “poor, ragged, tired, and dirty," but "good and honest" (Six Months 289). On the one hand, Bly attempts to dispute the common opinion in the U.S. that indigenous Mexicans are "indolent and lazy" (Ruiz 306). To this end, she tells U.S. readers to "put an American domestic and a Mexican servant together, even with the 
difference in the working implements, and the American will 'get left' every time" (Six Months 276). "But cleanliness," she adds, "may be confined somewhat to such work as sweeping and scrubbing; it does not certainly exist in the preparation of food" (Six Months 276). Here, though Bly tries to dispute the "historic complaint" of Mexican laziness, she nonetheless assigns indigenous Mexicans to the zone of U.S. domestic service. In this gesture, Bly interrupts one stereotype (Mexican laziness) only to promote another - that of the Mexican burden bearer. Instead of carrying packs on their backs, Bly suggests that indigenous Mexicans are ideal for bearing the burden of domestic labor in United States — an association that would define U.S. attitudes toward Mexican immigration for the next century.

Bly uses the image of disease as clear evidence of Mexicans' cultural backwardness and racial degeneracy. The perceived threat of disease often functioned as "sanitary justification for U.S. intervention" in Mexico in the late nineteenth and early twentieth centuries (Ross 584). As U.S. economic exchange with Mexico increased, many in the U.S. began to view this contact as a threat to public health. As a result, the U.S. government increased its efforts to develop a "system for the sanitary surveillance in central America" to ensure that, despite "contact" with Mexico, the U.S. would remain disease-free (Ross 584). Progressive Era commitments to disease and hygiene management framed discussions regarding the challenges of growing U.S. commerce with Mexico, a place many Americans associated with diseases like smallpox and yellow fever. Bly exacerbates the perception that Mexico threatens the U.S. with contamination, reporting that "small pox holds undisputed sway in the dirty streets" and that Mexicans refuse to vaccinate in the "name of religion," which suggests their primitivism and rejection of modern medicine. This rejection of modern medicine, as Paul Ross reports in his study of Mexico's Superior Health Council, is usually associated with Mexico's rural poor, though Bly locates 
smallpox in the Mexican "border town" of El Paso de Norte. The location of smallpox in El Paso De Norte suggests the proximity of foreign disease to the domestic U.S. The diseased border town, as McClintock puts it, leads to "paranoia about boundary order" (47). More specifically, McClintock argues that the discourse of contaminated or "bad" blood promoted "an institutionalized fear," which leads to "biological images of disease and pestilence that form a complex hierarchy of social metaphors and carry considerable social authority" regardless of whether or not a threat is legitimate (47).

According to Bly, disease spreads among Mexicans due to a general lack of cleanliness and hygiene, thus perpetuating common late-nineteenth century assumptions among U.S. Americans that those in Mexico were mostly savages (Jacobson 38). In a particularly telling scene, Bly explains that a Mexican crowd "is not a clean, inviting crowd, with blue eyes and sunny hair I would take you among, but a short, heavy-set people, with almost black skins, topped off with the blackest eyes" (Six Months 199). "Their lives," she continues, "are as dark as their skins and hair, and are invaded by no hope that through their effort their lives may amount to something” (Six Months 199). She observes "native Indian” women living in "huts" and "making their toilet—combing their hair with the same kind of brush they scrub with, washing their bodies with a porous soapstone common to the country" (Six Months 208). Despite the supposed lack of hygiene, the condition of the peons remains "most touching" because their lives are "worse off by a thousand times than were the slaves of the United States" (Six Months 203). Here, Bly mentions U.S. slavery as a way to make the racial dynamics of Mexico legible to U.S. readers at a time when state-sanctioned racism surged with the enactment of Jim Crow, the conclusion of Indian Removal, and enactment of race-based immigration laws. 
Though Bly critiques domestic arrangements in the U.S. and Mexico as too oppressive, she nonetheless identifies the "domestic realm" as a marker of civilized status in Mexico. Amy Kaplan argues that during the height of U.S. expansion, "domestic" took on a "double meaning that links space of the familial household to that of the nation" (Anarchy 25). Peon families, Bly writes, "have no home" and live in "mere holes in the ground" with only "scraps" of clothing and no personal possessions (Six Months 199). Considering Kaplan’s formulation, peons' homelessness (their wretched domesticity) begs the question: without a proper home, can Mexico be a proper independent Republic? Moreover, Bly's "reports" on the intimate habits of peons presents peons as object of visual pleasure for U.S. readers through images of abject poverty, nakedness, and a-typical sexuality. To this end, Bly also adds to turn-of-the-century discourses regarding Mexican women's sexuality and reproductive habits. Bly asserts that Mexican women "carry three babies at a time in her rebozo" (Six Months 199). The children know "no home, they have no school, and before they are table to talk they are taught to carry bundles on either the head or packs" (Six Months 199). Here, Bly shares a common cultural assumption of Mexicans' tendency toward over-reproduction, and calls Mexico a "hotbed of children," which prompts anxiety in the U.S. regarding Mexican's ability to assimilate to a modern culture (Six Months 262). Additionally, as Ruiz notes, images of nakedness or discussions of indigenous sexuality reflects an "American impulse to see poor Mexican women and girls as inherently desirable" and as "more inherently sexual — and more exploitable — than non-native women and girls" (38). And, according to Bly, "Mexican women like to be looked at" (Six Months 229). There is, of course, a clear racial component to Bly's assessment. While Bly considers reproduction in Mexico as evidence of an oversexed indigenous culture, white women's reproduction, as McClintock asserts, is considered a key method for "controlling the 
Bebell 124

heath and wealth of the male imperial body politic" (47). Even though Mexican immigration to the U.S. was still relatively small at this point, Bly's assessment and others like it, raised questions about Mexicans’ possible future assimilation into capitalist modernity—or even as potential future U.S. citizens. Passages about "thousands of babies" reflects U.S. anxieties, particularly at the turn into the twentieth century, regarding the preservation of the United States' white racial hierarchy.

Essentially, Bly views the condition of Mexico's poor as a humanitarian crisis that results from a government that refuses to "uplift" its poorest populations. Bly maintains that the Diaz regime strips its poorest citizens of their voting rights, land, work, and health care. Her criticisms were so vocal, in fact, that she fled Mexico one month early to avoid potential imprisonment for speaking against the Mexican government. Once safely back in the United States, Bly sharpens her critique and predicts a future rebellion in Mexico: "They know that Diaz is a tyrannical czar and want to overthrow him. It may be readily believed that Diaz knows they are bound to this superfluous feeling, and would much rather have them vent its strength on the Americans than on himself; thus he stands on war" (Six Months 297). It's hard to know what Bly means here by “war.” Perhaps, she means a revolution sparked by Mexico's indigenous populations, or perhaps she feels that Diaz has some latent desire for war with United States. The latter seems unlikely as diplomatic relations between the U.S. and Mexico were relatively stable at the end of the 1880s. There were still "more Mexico" debates swirling around Foreign Relations committees in Washington D.C., but, overall, talks of annexation—by force or negotiation—remained a minority opinion. ${ }^{13}$ Those who objected to annexing additional Mexican territory, despite potential economic benefits to the U.S., maintained that Mexicans posed a threat to the morals and ideals of the United States. In 1891, a Denver Post article made this point clear: "The 
Mexicans differ from the Americans in blood and language, and in many respects the civilization of the two countries differ. They would not unite. One government might be extended over both, but the two great sections would remain distinct. It would require hundreds of years to make the Mexicans and Americans alike and to establish the English language in place of the Spanish...These conditions forbid all thought of union between Mexico and the United States, whether peaceably or by force" (n.p.). In other words, for a variety of reasons, many U.S. Americans adamantly argued that Mexicans were incapable of assimilation into U.S. culture. U.S. politicians and citizens continued to debate the issues of Mexican difference and assimilation colloquially known as the "Mexico Problem," as more and more Mexicans crossed into the United States as the nineteenth century drew to a close. ${ }^{14}$ As Matthew Frye Jacobson reports, from 1906-1915 there were approximately 127,000 Mexican immigrants living and working in U.S. cities (41). Even more entered as migrant workers or seasonal laborers. As Mexicans became common fixtures in U.S. social culture, racial and cultural stereotypes, like those deployed through travel literature, shaped their experiences. Like other immigrant groups, many Mexicans faced an inhospitable environment in the United States, which persists into present day. More than one hundred and twenty years after Bly traveled to Mexico, the "Mexico Problem" still occupies a strong presence in U.S. domestic and foreign policy. As U.S. Americans look toward the 2016 presidential elections, and in almost every U.S. presidential election over the past twenty-five years, Mexican immigration is considered one of the "hot button" issues. In the current U.S. political context, anti-immigration rhetoric seethes with Hispanophobia in its demands to "secure the boarder" in order to stop "illegal aliens" from entering the country. Recently, conservative rhetoric surrounding Mexican immigration has taken on heightened tones of paranoia and racial intolerance. Business mogul/celebrity-turned- 
Republican presidential candidate Donald Trump's promise to "build a great wall" to keep Mexican "murderers" and "rapists" away from U.S. soil appears to have received a disheartening amount of public support among conservatives. ${ }^{15}$ That this message resonates with any U.S. citizen (let alone the tens of thousands represented by polling numbers and rally attendance) suggests the extent to which Mexico-and Mexicans-continue to be imagined as economically, culturally, and racially inferior to America within the U.S. imperial imaginary.

As the nineteenth century ended and the twentieth began, the United States continued to build its reputation as an emerging global power. The U.S. had gained possessions in the "American Pacific" and the Caribbean while continuing to exert influence in Mexico and Latin America. The following chapter shifts the frame of U.S. empire-building once more; I examine the transnational flow of imperialism in Edith Wharton's In Morocco. 


\section{Chapter Five}

Into the Bled: ${ }^{1}$ Edith Wharton's Islamic Morocco

\section{Introduction}

In a November 1920 article published in The Independent, a newspaper devoted to the “consideration of politics," an anonymous reviewer praises Edith Wharton's travel guide In Morocco for offering an "impersonal" view of her 1917 travels through the French protectorate as the guest of General Lyautey, the Resident General of French Morocco (242). ${ }^{2}$ This review of Wharton's work, aptly titled "Traveling by Proxy," suggests the importance of travel writers to U.S. readers' sense of the global. Travel writing, whether about Hawaii, Mexico, or Morocco, provides commentary on the time's most pressing social issues, including U.S. attitudes toward expansion, European colonialism, the woman question, and concerns over race and immigration. Moreover, Wharton's observations in In Morocco demonstrate how religious identity/affiliation impact categories of race, gender, and nation. Wharton describes Islamic Morocco as a modern "death world," and uses necropolitical narration to suggest the living dead status of Moroccans who continue to observe the violent, backward, and misogynist religious practices, such as blood-rituals and harem seclusion. In her description of Islamic traditions, Wharton's criticism of Islam takes on a distinctly racial tone wherein she creates a discursive link between death, violence, race, and Islam.

In Morocco sheds light on another sort of U.S. imperial fantasy, which is expressed through discourses of American Orientalism. In this case, however, it is not about making the foreign more domestic as part of the growing nation (as was the case in Hawaii), but about protecting the U.S. domestic space against the perceived threat of the foreign. Morocco was a French protectorate at the time of Wharton's visit and suggests the extent to which French empire building impacted the domestic culture of the U.S. U.S. possession over Hawaii and the 
Bebell 128

Philippines, along with U.S. economic control of Mexico, perhaps provide more straightforward examples of U.S. imperialism in action. But Wharton's work reflects how American Orientalism was a transnational phenomenon, which was mediated, in this case, through the lens of French colonialism. Shealeen Meaney notes that U.S. women who traveled to European-controlled colonial spaces often promoted U.S. moral and cultural superiority, thus filtering their impressions of European colonialism through an American lens (765). In this case, Wharton's rendering of French Morocco polices U.S. domestic space against perceived threats of Islam. Thus, although Wharton does not discuss a territory within the U.S. empire, her text is instructive regarding the role of imperialist discourse regarding the need to protect the nation against intrusions of the foreign within domestic borders.

In addition to Wharton's anti-Islam agenda, In Morocco provides insight into issues directly related to gender and racial politics in the U.S. in the early twentieth century. Most scholars use the word "ambivalent" to describe Wharton's gender politics. Elizabeth Ammons notes that Wharton's attitudes toward women's rights changed throughout her lifetime. Growing up in the affluent class of New City's elite, Wharton spent 1890s and early 1900s developing a theory of women's rights that fused "sociological, economic, psychological, and anthropological perspectives" (Ammons, Argument ix). As Wharton's fiction of this period demonstrates, Wharton was extremely critical of traditional marriage, which she likened to an economic transaction (Ammons, Argument 55). She objected to the notion that women were objects that could be "bought" and "sold" within the economy of marriage. Indeed, Wharton supported women's education and professionalism, but always felt like the women's movement was overly optimistic. Wharton criticized what she saw as a continuing U.S. preference for weak or infantile women despite gains made by suffragists and other reform-era women's initiatives. In fact, 
Wharton vocally dismissed the efforts of not only the suffrage movement but women's Progressivism generally. Mostly, Wharton objected to the "women's only" aspect of such initiatives. "Real civilization," Wharton maintained, necessitated "close and constant and interesting and important relationships between men and women" (French Ways 144). In French Ways and Their Meaning, Wharton claimed that female segregation in groups and clubs did not equate "real living" (French Ways 119). "No matter how intelligent women are individually," Wharton argued, "they tend collectively to narrow down their interests, and take a feminine or even female, rather than a broadly human view of things" (French Ways 119). Even worse, Wharton maintained that U.S. women's clubs "public investigation of everything under the heavens from the 'social evils' to 'baking powder"' were not enough to garner full political and professional citizenship for women (French Ways 120). Not surprisingly, Wharton remained “aloof” toward suffrage (Ammons, Argument 2).

By the time the Nineteenth Amendment passed in August of 1920, Wharton was growing more conservative in her gender politics. She became increasingly interested in issues related to motherhood and childrearing (Ammons, Argument 157). She admonished the 1920s "flapper" as an infantile woman shirking her national duty of motherhood and ignoring her responsibility for the preservation of white culture. This may initially seem a jarring departure from her position in the late 1890s and early 1900s when she identified marriage and motherhood as oppressive structures that turned women into mere commodities. However, much had changed during those crucial years. To start, the violence of World War I had made an indelible impression upon Wharton (especially its impact on war widows and children). Even as U.S. women were making real, tangible gains toward equality they were met with a conservative social backlash and a desire to recover women's more traditional roles. At the same time, African Americans were 
agitating for increased civil rights and immigration numbers in the U.S. were at a record highboth of which threatened Wharton's preference for racial uniformity as opposed to hybridity. Additionally, Wharton likely was influenced by her close friend Teddy Roosevelt's campaign against what he called "racial suicide." In short, Roosevelt argued that "the first and greatest duty of womanhood, able and willing to bear, and to bring up as they should be brought up, healthy children, sound in body, mind, and character, and numerous enough so that the race shall increase and not decrease" (n.p.). ${ }^{3}$

As the above shows, Wharton's gender and racial politics were deeply intertwined. In one of the only sustained studies of Wharton's views on race, Jennie Kassanoff identifies Wharton's racial politics as a brand of "conservative neo-nativism” (88). Wharton, who spent most of her later life living in France, associated America with "class, racial, and sexual hybridity" (Kassanoff 88). Kassanoff argues that Wharton "responded to the possibilities of racial and ethnic hybridity by forging a racial aesthetic...that encoded a deeply conservative, and indeed essentialist, model of American citizenship" (5). Wharton's fiction promotes "neo-nativist laws of 'pure English' and her colonial determination to suppress pure anarchy” thus providing an "aesthetic and political bulwark against the menacing possibilities of democratic pluralism" (Kassanoff 5). This chapter investigates Wharton's experiences as an American in a French colony and the space this creates to interrogate not only the cultures of French colonialism in Morocco but U.S. domestic culture as well. Specifically, I argue that Wharton's impressions reflect her xenophobia and her own sense of racial superiority. In the travel guide, Wharton identifies Islam as a savage religion practiced by non-whites - a holdover over from an ancient pre-civilized (i.e., pre-French) past. Wharton's impressions further reflect similarly held attitudes that proliferated U.S. popular and political discourse at the turn into the twentieth century. 
Moreover, Wharton racializes the practice of Islam in order to represent it as antithetical to white Western (and Christian) civilization.

Wharton's racial and gender politics clearly informed her attitudes toward expansion and imperialism and contributed to her imperial aesthetic. As the work of Frederick Wegener has shown, Wharton surrounded herself with well-known U.S. expansionists, including her close friend Roosevelt. ${ }^{4}$ Based upon her papers and letters, Wharton appeared to support U.S. imperialism along with French and British imperialism in the early years of the twentieth century. She even once identified herself as a "rabid imperialist" in a 1901 letter to Sara Norton (Letters 45). ${ }^{5}$ Wharton makes clear her total support for the French imperial project in Morocco, but does not directly address U.S. imperialism or U.S. culture. Nonetheless, In Morocco gestures toward its effects. As Meany notes, U.S. women who traveled to European colonies found space to "resituate themselves geographically" to order to deploy U.S. discourses "of liberty, modernity, and democracy in imperial contexts" (767). In other words, as a very well-known American author, Wharton could not help but signal American modernity as she traveled abroad even under the umbrella of French colonialism.

By the mid-nineteenth century, the American and European markets on travel guides were completely saturated. By 1900, Americans alone had published almost 2000 books of travel. ${ }^{6}$ In Morocco was not Wharton's first travel-themed book. Fifteen years before she visited Morocco, she wrote two travel accounts: Italian Backgrounds (1905) and A Motor-Flight Through France (1908). Mary Schriber notes that by the time Wharton began penning travel narratives, around the turn into the twentieth century, "the American book of European travel was exhausted" (148). In her preface to In Morocco, Wharton addresses this issue head-on. Morocco, she argues, is a novel place for an American-authored travel guide. According to 
Wharton, all that currently exists are travel accounts of Morocco written in French, which she calls "large and often inaccessible" (In Morocco x).

In Morocco underwent several editions and re-printings between the years 1919-1927. It was published in serial form and in whole. ${ }^{7}$ It appeared in well-read venues such as Scribner's Magazine and the Yale Review. Following In Morocco's 1920 publication, the travel guide was not reprinted until 1984. Compared to the rest Wharton's oeuvre, In Morocco has received far less scholarly attention by contemporary critics in both Wharton studies and studies of travel literature. Those critics that have studied In Morocco have primarily examined Wharton's support of French imperialism as an extension of her well-documented Francophilia. Others have examined her use of Orientalist tropes or her use of architectural description to illustrate networks of colonial rule, which again establishes Wharton's unwavering support of the French colonial project. No critic has yet offered a sustained study of Wharton's treatment of Islam throughout In Morocco as it relates to early-twentieth century U.S. culture, but they have offered various important insights and contributions regarding Wharton's identification with the French imperial project throughout her travel guide.

Wharton traveled under far different circumstances than Hamm, Krout, and Bly. Unlike Krout and Bly, who lacked support from their newspapers and had to finance their own travel, Wharton went to Morocco as the esteemed guest of the French Resident General Lyautey. According to one critic, Wharton received "VIP treatment" from the French colonial establishment (Hunter 62). General Lyautey provided Wharton with a motor coach, a military chauffeur as a driver, and a French staff officer" (Hunter 62). As Wharton emphasizes throughout In Morocco, there were few tourists to the French colony prior to 1917. Her trip dovetailed with a French initiative, also begun in 1917, to open Morocco to commercial 
Bebell 133

enterprises - namely tourism. By this time, Wharton was a well-known and celebrated American author, and it seems likely that General Lyautey saw the commercial potential in inviting Wharton to tour Morocco. Before travel began, Wharton had already arranged a deal with Scribner's Magazine as a publication venue for her travel sketches. Wharton spent a total of 41 days in Morocco (15 September through 25 October 1917) with the primary purpose of attending the French Fair at Rabat. General Lyautey, and his colonial functionaries, arranged Wharton's entire trip from start to finish. According to Wharton, her French "connections" assured that she'd see the country as no one had before.

Wharton's rhetorical choices throughout In Morocco are an example of necropolitical narration - a narration style that focuses on images of death, decay, and debasement. Wharton emphasizes such images as a potent reflection on death-obsessed Islam, but also as a possible reflection on what she viewed as the eventual death of white Anglo-America. Wharton's rendering of Islam serves as an example of the ongoing efforts of Western Orientalism to label Islam as violent, backwards, and antithetical to Western ideals. Not only does Wharton associate Islam with death, but she argues Islam's primary victims are women. Wharton describes Morocco and Moroccans through images of death that double as a "political metaphor" that represent Wharton's opinion that Muslims are a menacing threat to democratic ideals (Castonovo 1). The imperial context upholds this assertion. In a literal sense, France holds colonial power over Morocco and its inhabitants. Wharton supports French colonialism and uses her travel guide to promote the image of Muslim as a threat to U.S. audiences, an image that continues to haunt U.S. perceptions of the Middle East and North Africa.

Necropolitics, an extension of Foucault's theory of biopower, has been used to characterize the relationship between the sovereign and subject within the context of European 
colonialism and plantation slavery. Wharton's necropolitical narration shows us the extent to which discourses of necropolitics and necrocitizenship shaped U.S. approaches to and interpretations of imperialism abroad and policies at home. Wharton's support of French colonialism is deeply rooted in U.S. ideals of democracy and passivity which are often expressed through the language of death. Russ Castronovo traces the link between death and democracy in U.S. discourses of citizenship and national belonging. He writes, "state and citizen are mediated by necrophilic conjunctions of aversion and desire: fear of the dissolution or death of the state creates the longing for an inactive, forever tranquil citizenry; meanwhile, the continued stable existence of government requires historically dead subjects. The metaphor of death has exerted real pressures in falsely idealizing passivity and disconnection as democratic virtues" (8). Nowhere is this phenomenon more obvious than in a colonial context wherein passivity of subjects is not just preferred but it is required in order for the colonial hierarchy to thrive.

Throughout In Morocco, Wharton uses “metaphors of death" in her description of Arabs and black Moroccans living under French colonial control. She uses her literary skill to create elaborate portraits/deathscapes of Morocco that are littered with macabre images of blood, death, graveyards, ghosts, and other ghoulish imagery. In short, Wharton creates a "death world" occupied by "the living dead" or what Agamben might characterize as "bare life" (Mbembe 40, Agamben 9). Wharton's descriptions of Morocco demonstrate and celebrate France's success in creating seemingly docile colonial subjects. At the same time, Wharton's necropolitcal narration also seeks to associate the practice of Islam with political death, corporeal violence, abuse of women, and blackness. ${ }^{8}$ Moreover, Wharton's In Morocco is a reflection of the tense relationship between democracy and death in the U.S., and also adds to popular and political discourses regarding the growing anxiety over Islam, race, and immigration in the U.S. at the turn into the 
Bebell 135

twentieth century. Further, Wharton's rendering of Islam serves as an example of the ongoing efforts of Western Orientalism to label Islam as violent, backwards, oppressive, and antithetical to Western ideals. Wharton presents Islam not just as a religion but as "part fiction, part ideological label" (Said, Covering 1).

\section{Arabian Africa: Orientalism and Islam in U.S. Culture}

The arabesques that circulated in U.S. culture in the early twentieth century were created and sustained by discourses of Orientalism and Islamaphobia, which were informed by a longstanding U.S. fascination with the Arab world. ${ }^{9}$ Since the country's inception, the U.S. had an interest in Arab culture, Islam, and North Africa. During the colonial period, as Timothy Marr points out, "Patriots used islamicist images of Muhammed and the excesses of contemporary Sultans as useful models to dramatize the injustice of British exploitation of their dependent colonies" (20). In the early days of Republic, the U.S. was involved in what became known as the Barbary crisis. The U.S. engaged in a series of military confrontations with the "Barbary states," which were under the control of the Ottoman Empire, over U.S. refusal to pay tributes on merchant ships. Throughout the conflicts, from about 1801-1815, the public learned of incidents wherein Barbary pirates raided U.S. ships, kidnapping and enslaving crew members. The cultural response to political engagement in the Muslim Mediterranean manifested itself in publications like An Algerine Spy in Pennsylvania, The Algerine Captive, and Slaves in Algiers. ${ }^{10}$ These texts promoted images of the Islamic world as politically despotic, culturally backward, and savage whereas the U.S. was idealized as democratic, modern, and civilized. As Marr points out, "events in the Muslim Mediterranean (and in the broader Islamic orient) enabled worldly-minded Americans to affirm upon a global stage — through both historical and rhetorical means - the humanity of their own cultural practices, the relevance of their new political system, and the 
heroism of their men and women" (Marr 22). Ultimately, these political events and cultural materials helped the U.S. define itself as a nation while fostering what would be a continual fascination/fear regarding the Islamic world.

At the turn into the twentieth century, the U.S. continued its fascination with North Africa. In the context of popular culture, the U.S. reading public encountered several works on the region of North Africa or Arabness, including Robert Hitchens's Garden of Allah, P.C. Wren's Beau Geste, and Edith Hull's The Sheik. ${ }^{11}$ Brian Edwards examines the intense U.S. interest in the "Maghreb" beginning in the late nineteenth century. ${ }^{12}$ Edwards notes that "the Maghreb was one of the most familiar locations of the American exotic and one of the places to which filmmakers and novelists turned often for tales of the 'Oriental' splendor and decadence" (1). Edith Wharton was aware of American's penchant for the literary arabesque in popular culture. As such, Wharton places In Morocco within a broader body of work that depicts North Africa through references to classic texts like Arabian Nights. ${ }^{13}$ Early in the travel guide, Wharton tells readers that "everything that the reader of Arabian Nights expects to find is there" (In Morocco 21). Wharton further plays upon popular images of Arab and Oriental culture by frequently mentioning "Djinn's carpets" and other exotica (In Morocco 3). She describes "the whitewashed niches wherein pale youths sit weaving the fine matting for which they are still famous; the tunneled passages where indolent merchants with bare feet crouch in their little kennels hung with richly ornamented saddler and arms, or with slippers or pale citron leather and bright embroidered babouches" (In Morocco 24). Yet Wharton's initial impression of Morocco's "Oriental color and gaiety" is quickly replaced by visions of a "melancholy underworld" (In Morocco 59). 
Despite the American public's interest in the arabesque, most Americans perceived actual Muslims as a threat to the body politic. The perceived threat of Islamic influence in the United States was reflected in contemporary newspapers circulating in the U.S. at the turn into the twentieth century. The articles published during this time suggest U.S. citizens concern over the "spread" of Islam. For instance, titles of news articles included "The Spread of Islam" (1906), “The Crisis of Islam" (1912), and "The Moslem Menace” (1911). The titles alone suggest a general anxiety regarding the impact of Islam on U.S. citizens' sense of cohesive (i.e. white, Christian) national unity. Taken together with Wharton's travel guide, popular circulating “secular" newspapers present Islam as something that needs to be contained, controlled, and eradicated. For example, "The Moslem Menace” published in The Outlook in 1911 articulates this concern and provides context for Wharton's journey to Morocco just a few years later. The reporter notes that the "fear of such a revival in Mohammedanism is a quickly approaching reality: Mohammedanism is making marvelous progress in the interior of Africa. It is crushing paganism out. To-day, so rapid has been the spread of Islam, the voice of the muezzin from his minaret calling the faithful to prayer is heard from Cape Verde straight away to the shores of the Pacific Ocean" (Powell 369). Another article, aptly titled "The Spread of Islam" warns of a similar scenario in which the "Sultan is organizing a movement of revival of Mohammedanism throughout the world" resulting in "the bringing of recruits from other religions" and an "enormous increase" in the followers of Islam (New York Tribune 106). Other reports communicate anxiety over the spread of Islam using raw data. For instance, in 1909 The Independent reported a rise in "confessors of the faith" totaling "223,985,780" Muslims in the "whole world," many living covertly under "Christian governments" (614). If U.S. readers remained unfazed regarding the spread of Islam, the author also notes the following statistic: 
“there at least 56,000 confessors of Islam" living within U.S. borders (614). Taken together, this sample of articles suggest that many U.S. citizens regarded Islam as a threat to the otherwise unified U.S. citizenry. Moreover, popular media sources often presented Islam as a diseased/dangerous element within the otherwise healthy/safe U.S. body politic.

Wharton's rendering of Islam falls in line with the already established rhetoric promoted by the newspapers excerpted above. Throughout In Morocco, Wharton supports popular contemporary notions that Islam was a religion that is "distinct and separate [from] culture and civilization" (Current Literature 415). The newspapers and Wharton's take on Islam are early examples of what Edward Said labeled "covering Islam.” According to Said, "covering Islam" refers to the ways that media and news outlets present Islam to Western audiences through the lens of Orientalism. Specifically, Said asserts that "the term Islam as it used today seems to mean one simple thing but is in fact part fiction, part ideological label, part minimal designation of a religion called Islam" (Covering 1). In "covering Islam” Western media sources have often perpetuated "patent inaccuracies...expressions of unrestrained ethnocentrism, cultural and even racial hatred, deep yet paradoxically free-floating hostility" (Said, Covering li). Though Said pulls his examples from late-twentieth-century media coverage of the Iranian hostage crisis, one cannot help but see that this discursive process was already firmly in place at the turn into the twentieth century.

As evidenced by the periodicals, the "spread" of Islam was perceived by many Americans as a legitimate threat. Wharton accentuates that threat as she describes Muslims as hoards, swarms, and frenzied bodies. Like contemporary periodicals, In Morocco contains imagery of Muslims that are meant to overwhelm the Western reader. Wharton expresses concern over "draped, veiled, turbaned mobs" and "ashen crowds swarming gloomily through 
the dark tunnels" (In Morocco 60). Wharton expounds on this further when she visits Fez noting that "one looks, on the plan of Fez, at the space covered by the bazaars, one breasts the swarms that pour through from dawn to dusk — and one remains perplexed and disappointed" (59). Wharton's confusion and disappointment stems from a disconnect between one's expectation of Morocco (as articulated by her comparison to Arabian Nights) with the reality of "mobs" and "swarms" that disrupt the "Oriental splendor" that Wharton expects to find. The contrast between what Wharton expects and what she finds reflects a contradiction: American readers had a fascination for arabesques in the form of stories yet an intolerance for actual people who identified as Muslims, and especially those living within the United States. Contemporary newspapers and Wharton's choice to describe groups of people in threatening terms ("swarms," "hoards," and "mobs") reflects a similar anxiety among readers regarding the U.S. (and by extension the West) being overrun with Muslims.

Wharton's presentation of Moroccans as bare life neutralizes the perceived threat of Muslim presence in the United States. The "swarms" that Wharton encounters are mostly nonspecific, faceless masses of draped figures. To this end, many of the Moroccans that Wharton describes for readers are stripped of individual agency and are reduced to a mere physical presence without any political autonomy. The discursive process of reducing Moroccans to bare life is made possible via the context of French colonialism, which imposed a hierarchy between those in positions of imperial power and those who are subject to it. Though Wharton is not a formal member of the French imperial cohort, she does travel as a guest of the Resident General. Wharton's descriptions may also serve to neutralize the perceived threat of Muslim presence in the United States; as Wharton describes it, most of the Muslims she encounters are well controlled within the French imperial network. 
Bebell 140

Aside from the peoples of Morocco, Wharton spends time discussing the geography of Morocco and continues to use language affiliated with death. Wharton describes Morocco as part African and part Arabian. Edwards points out that for many early twentieth-century Americans North Africa offered the perfect space in which to observe the practice and potential spread of Islam, but it also provided a space to observe "internationalism in action" along with the "global flow of Orientalist discourse" (Edwards 2). Edwards notes that many Americans viewed the geographical space of Morocco as "both African and Arab and this provoked many Americans to see a complex series of possibilities — neither simply 'Oriental' antithesis to the West, nor African "blackness"' (4). Wharton supports the concept that Morocco is a space that is both Arabian and African (a point that becomes essential in Wharton's conflation between Islam, Arab, and blackness). Wharton draws on stereotypes familiar to both Arabia and Africa. She writes that "it is one of the surprises of Morocco to find the familiar African pictures bathed in this unfamiliar haze" (In Morocco 17). The unfamiliar haze that Wharton describes constitutes the "Arabness" of Morocco. She continues, "Morocco is Tunisia seen by moonlight" (In Morocco 17). In these passages, Wharton argues that brash Africa is somehow tamed and enhanced by its "Oriental" influence. Yet Wharton surmises that Morocco "seems not be Africa itself, but...the Africa crusaders dreamed of" (In Morocco 24, 28). Wharton's mention of the crusaders reminds readers of the holy wars that demanded the conversion to Christianity. Even though the Crusades occurred centuries before Wharton's birth, she still uses the familiar reference to remind readers of the extent to which the ideological "war" between Christianity and Islam continues well into the twentieth century. 
Bebell 141

\section{Into the Shadowland: Islam vs. Christianity}

Wharton presents French Morocco as an ideological battle ground between Western Christianity and Eastern Islam. In Morocco contains several instances where Christian "dignity" confronts Islamic "barbarity." She begins with a comparison between Roman and Islamic architecture. One can see the confrontation between the two faiths in Wharton's descriptions of Roman ruins versus the ruin of a Muslim city: "So the two dominations look at each other across the valley: one, the lifeless Roman ruin, representing a system, an order, a social conception that still runs through all our modern ways, the other, the untouched Moslem city, more dead and sucked back into an unintelligible past more than any broken architecture of Greece or Rome" (In Morocco 31). In this passage, the distance between Islam and Christianity is emphasized by the valley that separates the two former cities. Rome represents order and has left a rich legacy for Western culture to emulate, while the Muslim city is merely "dead" and sucked back into an unarticulated past. According to Wharton, even the formerly "Christian" spaces of Morocco contain relics of their Islamic past. She concludes that "even in the new thriving French Morocco, the outline of a ruin or the look of a pair of eyes shift the scene, renders the thick veil of European illusion and confronts one with the old grey Moslem reality" (In Morocco 23). Here, perhaps unwittingly, Wharton suggests the possibility for resistance to the French imperial project. A "look of a pair of eyes"- a vestige of Islam — is enough to lay bare the "illusion" of French colonial order.

Despite occasional moments where Wharton reveals the tenuousness of French colonialism in Morocco, she overwhelmingly asserts that as Morocco "progresses" it will lose all vestiges of Islam and thus remain "alive" (i.e., modern). Wharton believes that Islam is merely part of the past, uncivilized, pre-colonial Morocco. According to Wharton, at the time of 
her visit, Morocco is at a point of "abrupt transition from remoteness and danger to security and accessibility" (In Morocco 12). This transition has clear religious overtones. Wharton maintains that this particular historical moment (1917) offers a rare glimpse into what has previously been off-limits to white, Western, Christian, and female travelers. Specifically, she argues that nonMuslims finally have access to the previously hidden parts of Morocco: "The Christian might taste the transient joy of wandering unmolested in the cities of ancient mystery and hostility, whose inhabitants seem hardly aware of its intrusion" (In Morocco 12). In other words, Christians can freely explore Islamic Morocco only because of the protection offered by the French colonial administration. However, Wharton still encounters the "threat" of Islam. Even with French protection, Wharton tells her readers that there still is animosity toward Christian visitors in Morocco. While waiting to view the Saadian Tombs and mosque, Wharton tells readers that "almost mysteriously, permission was given to us to visit the tombs of the Saadian Sultans" (In Morocco 77). When their guide never shows up to take them through the tombs, Wharton explains that "we waited in vain. Oriental dilatoriness, or at least secret reluctance to admit unbelievers to a holy place, has caused the Cadi to forget his appointment" (In Morocco 77). Here, Wharton acknowledges that some "holy places" in Islamic Morocco will remain offlimits to her despite her association with French colonial authority. In this instance, religious affiliation seems to trump colonial affiliation.

Now that we have considered Wharton's attitudes toward Islam generally, it is important to examine the attributes that Wharton associates with Muslims. According to Wharton, Islam lacks the integrity and sincerity of Christianity. Those who practice Islam strike Wharton as disingenuous and insincere. Wharton describes "confessors of the faith" as "sordid heaps of humanity" that litter the Moroccan landscape. She seems to depart from this description while 
traveling to Volubilis as she encounters a scene she can only assume is a "mirage": "There was something celestial, almost diaphanous, in the hundreds of figures turbaned and draped in white marching slowly through the hot colorless radiance of the hot colorless sand" (In Morocco 29). Wharton first notes the tranquility and aesthetic beauty of what she sees; "celestial" stands in stark opposition to the death world she encounters prior to this moment. After pondering the scene, Wharton brings her reader back to reality when she notes that "instantly the holy men [previously described as "turbaned figures"] became prey to the darkest passions" (In Morocco 29). She reports that "even in this land of contrasts the transition from pious serenity to rapacious rage can seldom have been more rapid" (In Morocco 29). She continues, "The devotees of the marabout fought, screamed, tore their garments and rolled over each other with sanguinary gestures in the struggles for our pesetas; then, perceiving our indifference, they suddenly remembered their religious duties, scrambled to their feet, tucked up their flying draperies, and raced after the trail end of the procession" (In Morocco 29). Wharton's description of the procession as "sanguinary" calls to mind images of self-mutilation and bloodshed. In the passage, Wharton presents the peaceful, non-fanatical practice of Islam (her fleeting celestial scene) as a mere performance. The "devotees of the marabout" (marabout refers to a Muslim religious teacher) transition abruptly from "something celestial" to a writhing, blood-thirsty mob. In Wharton's estimation, there is no "real" Islam except that which is volatile and fanatical. For Wharton, anything else is mere illusion.

\section{Death, Race, and Islam}

Wharton further describes the Moroccan landscape, people, and practice of Islam in terms and images associated with blackness and death. Wharton describes a kind of "living death" in her description of non-white Moroccans (Clough and Willse 8). Generally, a living death refers 
to a type of population racism that is related to necropolitics. Population racism occurs when segments of a given population (in this case Arabs and blacks living in Morocco) are viewed as non- or sub-human (bare life) and are completely under the power of the governing body. Wharton relegates most Moroccans to the status of the living dead, which works to consolidate and ensure French colonial control over the protectorate. ${ }^{14}$ If Moroccans are reduced to bare life, it is easier for France to maintain complete control. As Patricia Holland notes "by ensuring control of the corpse, society ensures control of its opposite, the living nation" (31). In other words, by relegating Moroccans to the living dead, Wharton can celebrate the success of the French colonial administration in Morocco. Wharton promotes the idea of Morocco as a modern death-world in need of salvation in at least two ways. First, In Morocco is a clear example of Wharton's support for French colonialism; since Morocco is on the precipice of social and political death (mostly due to its association with Islam), French re-birth via colonial control is necessary to the survival of Morocco as a modern nation. Second, Wharton's critique of Islam as a religion of blackness, fanaticism, and death operates as evidence of anti-Islamic and anti-black attitudes in the U.S. at the turn into the twentieth century.

Wharton's choice to racialize the practice of Islam as a non-white practice reflects the historical process described by David Theo Goldberg wherein "the figure of the Muslim, alongside that of the Jew, has historically book-ended modern Europe's explicit historical anxieties about blackness. 'The Muslim' has haunted the continent from the earliest moments of its modernity" (163). Wharton's status as an American traveling through the French protectorate adds to a more global understanding of not only Orientalist discourse but also U.S. attitudes toward Islam within in the context of a European-controlled colony. Morocco's proximity to 
both the Middle East region and Africa lends itself to a complex analysis of Wharton's critique of Islam as a defining feature of both Arabian and African cultures.

The framework of population racism fits within the broader colonial ideologies that legitimated French colonial control in Morocco. It's obvious before even reading In Morocco that Wharton aligns herself with French imperialism. Clear evidence of this is found in her dedication of In Morocco: “To GENERAL LYAUTEY: Resident General of France in Morocco... Thanks to whose kindness the journey I had so long dreamed of surpassed what I had dreamed" (n.p.). In addition to dedicating In Morocco to the single most visible representation of French colonialism in Morocco, Wharton also discusses Morocco as a country on the verge of death without the aid of French intervention. According to Wharton, Moroccans are "perpetually struggling to reach some higher level of culture from which they have always been swept down by a fresh wave of barbarism" (In Morocco 80). She continues, “They are still only a people in the making. It may be that the political stability which France is helping them to acquire will at last give their higher qualities time for fruition" (In Morocco 80). In other words, Wharton asserts that the French may be able to save Morocco from its own eventual death.

In a literal sense, Wharton uses language and imagery associated with death throughout In Morocco to further support the necessity of French colonialism and to racialize those who practice Islam. Wharton's description of the "real Moghreb [sic]" is one of dead landscapes and dead inhabitants. Throughout In Morocco, Wharton is preoccupied with numerous "solitary tombs," "saint's graves," and "white draped riders" that she encounters throughout her trip (In Morocco 14). Wharton describes the immense bled as an "earth devoid of life" that is marked with “a great emptiness" (In Morocco 14). As her travel guide continues, Wharton recounts being surrounded by images of death. Wharton traverses the bled via motorcar and muses that 
"death and desert [are] forever creeping up" to overwhelm the Western traveler (In Morocco 22). According to Wharton, even those traveling through Morocco must "enjoy a certain fatalism" to overcome the sense of death that accompanies such journeys to the proverbial underworld of Africa (In Morocco 26). Judith Funston argues that Wharton's trip to Morocco is akin into a "decent into hell" based on the language that Wharton uses to describe her encounters (3). ${ }^{15}$ Wharton explains to the reader that the "real Moghreb" is a collection of "dark tunnels" and "ghostly passages," which are "devoid of any color or laughter" (In Morocco 60, 63). Wharton reduces Moroccan universities to "dead houses of learning" and claims that all of "old" (i.e. preFrench) Morocco is "dying, just as her learning and commerce have died" (In Morocco 26). Wharton extends her description of "real Moghreb" beyond descriptions of place to the living dead inhabitants of Morocco. Holland notes that it is common for colonial powers to equate the colonized with the dead: "the living seeks nation status, and the dead serve as the signifiers of that loss, of that impossibility. But what is even more macabre is the colonial power's ability to render the subjected population as "dead"' (25). Wharton notes that most of the inhabitants of Morocco are non-descript "draped figures...like shadows on the way to Shadowland" (In Morocco 64). At the time Wharton was writing "shadowland" referred to an "abode of ghosts and spirits," or an "indiscriminate space" (Online Etymology Dictionary) ${ }^{16} \mathrm{Her}$ figurative description of shadows and shadowlands mirror her articulation of necropolitics when she describes Moroccan lives as "squalid and indifferent [who] work among grave sites" (In Morocco 57). Wharton takes this a step further and notes the close proximity (or lack of distinction) between life and death in Morocco. She notes that "there is such little separation between the living and the dead" (In Morocco 57). 
Wharton considers this lack of separation between life and death odd, unnatural, and a fundamental characteristic of native Moroccan life and by extension the Islamic tradition, which according to Wharton fetishizes death. Specifically, she notes the predilection of Moroccans to work and socialize on gravesites among the "unknown dead" (In Morocco 57). It bothers Wharton that graves are not demarcated or separated from public space. She notes that the graves are not "enclosed, but, as in most Moroccan cemeteries" are located in non-designated areas where "perpetual lines of camels and donkeys trample the dead a little deeper into the dusty earth" (In Morocco 56). For Wharton, the landscape is a place of death, a mere Shadowland, and those who occupy the landscapes a merely ghosts. In Wharton's travels through the "ghostliest Medersas" she notes the utter "absence of life" (In Morocco 21, 19). Wharton's assertion that there is an "absence of life" in Morocco stands in contrast to her descriptions of draped hordes and swarms of Moroccans. Yet this makes sense if we remember that Wharton's necropolitical narration strips inhabitants of life in favor of bare life - an existence that is reduced to a bodily presence but little else. In this way, Moroccans, like ghosts, haunt the landscape but do so without any acknowledgment of their status (or lack thereof) as a political subjects.

Wharton's identification with Christianity is unquestionable. ${ }^{17}$ Wharton inserts Christian mythos throughout her travel-guide as a way to narrate her experiences. I maintain that this action is a form of epistemic violence wherein Wharton places Christianity above the practice of Islam. Two clear examples are when Wharton uses the biblical Lazarus narrative and her cooption of the language of Christian burial rights. Wharton refers to the Christian biblical story of Lazarus of Bethany to describe the "waste space of intermural Fez, formerly the lines of defense of a rich perpetually menaced city, now chiefly used for refuse-heaps, open-air fondaks, and dreaming places for rows of Lazaruses rolled in their cerements in the dust" (In Morocco 81). In 
the New Testament of the Christian Bible, Jesus resurrects Lazarus from the dead claiming, "I am the resurrection of life. He who believes in me will live, even though he dies; and whoever lives and believes in me will never die" (John 11.38-44). Wharton's logic suggests that the "rows of Lazaruses" can only be saved by Jesus Christ, suggesting the power of Christianity over death and by extension over Islam. Again, Wharton likens those she sees in Fez to the living dead literally wrapped in "cerements," burial clothes, lying in the dust awaiting a presumably Christian resurrection.

A second example of Wharton's superimposition of Christian ritual in Islamic space occurs in her recital of Christian burial rights. Wharton tours the abandoned dwellings of Fez and concludes that "Dust to dust' should have been the motto of the Moroccan palace-builders" (In Morocco 49). The quotes around "dust to dust" indicate that Wharton consciously drew the phrase from the Christian tradition most closely linked to death. She mentions this a second time when she considers the "melancholy" nature of Fez (In Morocco 52). For the most part, Fez does not meet Wharton's expectations. She writes that in Fez "the lack of carved shop-fronts and gaily adorned coffee houses, and the absence of painted coffers and vivid embroideries of Tunis, remind one that Morocco is a melancholy country, and Fez a profoundly melancholy city" (In Morocco 52). Wharton describes everything that Morocco lacks in a similar vein to what Goldberg describes as "the collection of lacks" that dominates imagery of Islam in the West (163). Moreover, Fez is so melancholy that, according to Wharton, it is on the verge of death. Following her description of the "melancholy city," Wharton continues, "Dust and ashes. Dust and ashes, echoes from the grey walls, the moldering thatch of souks, the long lamentable song of the blind beggars sitting in rows under the feet of the camels and asses...the population goes mournfully by in earth-color" (In Morocco 52, emphasis original). 
In the two examples above, Wharton creates space for a confrontation between Christianity and Islam, an ideological showdown of sorts. Wharton's direct mapping of a Christian identity onto contexts where it does not apply creates a tension between the two religions that is upheld throughout the text. Wharton clearly believes that Christianity has already emerged as the superior, more civilized religious tradition. Wharton identifies Islam as a dying religion that mirrors crumbling Morocco: "The old religious fanaticism of Sale is dying also as her learning and her commerce have died" (22). Wharton is a product of the Western view that Islam was “diametrically opposed” to Christianity and European and U.S. culture (Subair Majaj 323). Symbolically, In Morocco reads as a long drawn out funeral for pre-French (i.e., ancient) Morocco and Islamic traditions.

In her description of Islamic traditions, Wharton's criticism of Islam takes on a distinctly racial tone. Wharton creates a discursive link between death, violence, race, and Islam. As such, Wharton's support of Christianity and her criticism of Islam have direct links to the ideologies of race and civilization. Lisa Subair Majaj argues that essential to notions of "race is Christian identity" (323). In the West, as seen in the newspaper excerpts, Islamic culture "was viewed as diametrically opposed to European culture" (Subair Majaj 323). Through the description of certain Islamic practices, Wharton reinforces that Islam is fanatical, violent, deadly, and nonwhite. Wharton's association of Islam with violence is most apparent in her recollection of Muslim rituals. Specifically, Wharton observes the Hamadchas ritual from her hotel terrace. As if she is viewing a performance staged for her viewing pleasure, she notes that she was an observer "of some extravagantly staged ballet" (34). Her choice of "ballet" is peculiar since she describes the ritual dance as "a blood-rite": 
Bebell 150

The dancers were all dressed in white caftans or in blue shirts of the lowest classes. In the sunlight something that looked like fresh red paint glistened on their shaved black or yellow skulls and made dark blotches on their garments. At first these stripes and stains suggested only a gaudy ritual ornament like the pattern on the drums; then one saw that the paint, or whatever it was, kept dripping down from the whirling caftans and forming fresh pools among the stones, that as one of the pools dried up another formed, redder and more glistening, and that these pools were fed from great gashes which the dancers hacked in their own skulls and breasts with hatchets and sharpened stones. The dance was a blood-rite, a great sacrificial symbol, in which blood flowed so freely that all the rocking feet were splashed with it. (In Morocco 35)

Wharton's description of this blood-rite is both grotesque and gratuitous. She creates an arabesque, wherein a Western fantasy of an Arab other "displaces the physical, material world in favor of an imagined world" (Rama-Berman 16). In this case, Wharton creates an arabesque that consolidates and links self-harm/destruction with race, violence, Islam.

Wharton maintains the binary between Christianity and Islam and by extension between West and East and white and black respectively. As such, her description of Moroccans, and the Hamadchas dancers specifically, rely on overt racial overtones. She identifies the Hamadchas dancers as "yellow" or "brown" and as a "bestial horror" comprised of both Arab and black participants (In Morocco 35). She suggests their sub-human or animal status to further advertise Morocco's need for colonial intervention, but also as an effort to align blackness (really, nonwhiteness) with Islamic practices.

In her descriptions of Islam and Muslims, Wharton creates a racial hierarchy that is reflective of her own conservative racial politics. According to Kassanoff, Wharton's attitudes 
toward race within the U.S. were "deeply conservative and indeed essentialist" (5). In her fiction, Wharton reacts against what she felt was the "hybrid origins" of the United States and she resisted notions of cultural diversity and the "pluralist excess of life in the U.S. (Kasinoff 7). In Morocco provides a non-fiction example of Wharton's racial politics within the international context of imperialism. Spencer Segella argues that Wharton used the travel guide "to advance her own racial views and not those of the Protectorate leadership" (24). In other words, Wharton's views on racial politics were structured by an American framework. It is important to note that Wharton's understanding of "race" could and did encapsulate factors beyond skin color, including nationality, ancestry, and religious beliefs. In the case of In Morocco, Wharton combines/collapses two of these factors: race and religion.

During her observation of the Hamadchas ritual, Wharton considers the different "roles" occupied by Arab ("yellow”) and black ("negro") participants to advance her critique of Islam. In doing so, the reader sees a shift in Wharton's well-documented conservative racial politics to a slightly more progressive position. Wharton scholars suggest that blacks occupy the lowest rung on Wharton's racial ladder. However, Wharton dislikes the practice of Islam so much that she takes her "lowest" racial preference and positions them as pitiable victims of a despotic religion. Wharton differentiates between several racial categories in Morocco: Arabs, blacks, Jews, and Berbers. Yet I would argue that Wharton identifies Arabs as the ultimate object of her racial distrust due to her equation of Arab with Islam. During the Hamadchas ritual, Wharton provides a seemingly out-of-place critique of the Arab treatment of black Moroccans within the context of Islam. She observes that during the ritual "it became evident that many of the dancers simply rocked and howled, without hacking themselves, and that most of the bleeding skulls belonged to the Negroes" (In Morocco 35). She continues, "Every now and then the circle widened to let in 
another figure, black or dark yellow [who] were suddenly 'getting religion' and rushing forward to baptize himself with his own blood" (In Morocco 35). Her description emphasizes the racial nature of what she's viewing; at this point, Wharton even modifies "yellow" with "dark yellow" to highlight the non-whiteness of Arab participants in the ritual. Here, Wharton offers an unexpected defense of black Muslims who participate in the Hamadchas ritual. According to Wharton, the ritual has an Arabic ring-leader who takes advantage of black slaves. She describes an "inspired looking creature" who "whirled about on his axis, black ringlets standing out in snaky spirals from his haggard beard" (In Morocco 34). She continues her description of the man leading the ritual as the "only calm figure in the tumult" who "moved gravely here and there, regulating the dance, and stimulating the frenzy" (In Morocco 39). Wharton feels compassion for those who merely participate in the ritual (mostly black slaves) under the direction of the leader. According to Wharton, "there is something far more sinister in this passionless figure, holding his hand on the key that let loose such crazy forces, than in the poor central whirligig” black participants (In Morocco 35). Wharton is critical of what she views as the coercion of black Moroccans to participate in a self-harming ritual in the name of Islam. Wharton tells the reader that one's role in the ritual is determined by their racial status. Participants divide "their racial duties into two classes, the devotions of the free men... and slaves" (In Morocco 36). The slaves must experience the bloodshed, or what Wharton refers to as "a horrid end" to the ritual (In Morocco 36). So, even though Wharton was known for her racial intolerance, she argues that even black slaves deserve protection from the violence and fanaticism that she associates with Islam. 
Bebell 153

\section{"White Slavery" in the Harem}

Wharton reports that she is especially interested in the lives of Moroccan women, which were usually presented by Western travelers as totally inaccessible. Wharton feels compelled to describe the "grave-clothes" covering native women even noting their symbolic allure. After her first "sighting" of a native woman, Wharton writes that "all the mystery that awaits us looks out through the eye-slits in the grave clothes muffling her" (In Morocco 71). According to Wharton, the "mystery that awaits" lies beneath the native woman's veil. "Lifting the veil" is a common trope in white women's travel writing, since they had access (unlike men) to harems and other spaces inaccessible to male travelers. Wharton eagerly accepts an invitation to "the Sultan's harem" as a guest of Lyautey's wife. Prior to the visit to the harem, Wharton only catches quick glimpses of native women who she describes in fairly overt eroticized terms. She tells readers of the "swaying hips" of the "lusty slave girls" in the bazaars (In Morocco 71). She describes "bluebronze negresses bear from the waist up" contrasted with Arab women who are draped in layers "grave-clothes" (In Morocco 47). Before she's granted access to the harem, Wharton describes her attempt to see underneath two Arab women's "ashy mufflings" in order to more clearly view “their light veils, long earrings and caftans" (In Morocco 54). Wharton contrasts Arab women as covered in "grave-clothes" and "ashy mufflings" with "negressess" who are usually described in highly sexualized terms. Wharton finds fault with both ends of this spectrum (totally repressed or overly sexual) and maintains that all women —Arab and black — are victims of the patriarchal insistence in Islam.

When Wharton finally visits a harem, she immediately identifies the space a "smoldering prison" of "sexual enslavement" (In Morocco 84). But more, the visit to the harem prompts Wharton to consider the impact of the exposure to Islam on one's sense of gender and national 
identity. It is safe to say that this section of Wharton's travel guide, "Harems and Ceremonies," has garnered the most critical attention from contemporary critics. Many readers suggest that this section primarily functions as a "mouthpiece" for Wharton's gender politics (Tromly 239). ${ }^{18}$ In the popular imagination, the harem was synonymous with idleness, overt sexuality, and unchecked patriarchal power — characteristics that Wharton detested (Grewal 50). As such, it made an ideal place for Wharton to construct an argument for women's rights in the U.S. Even though Wharton was ambivalent about suffrage and less than supportive of women's Progressive-era initiatives, she nonetheless criticizes the harem as a "smoldering prison" where the "whole structure" of society "hangs on the whim of one man" (In Morocco 84). Moreover, Wharton's interpretation of the harem — as a space defined by sexual slavery—reflects another growing concern in the U.S. at the turn into the twentieth century: the "moral panic" over forced prostitution, which was commonly referred to as "white slavery." In the context of the U.S., as in the Moroccan harem, the "slavers" are often depicted as racially marked and as a threat to white womanhood. America's early twentieth century obsession with white slavery signaled “American's anxieties with female kidnapping and coerced prostitution" and reflected "America's deepest sexual fear" of "immigrant males possessing the daughters of the land while their men stand by unable to protect" (Lui 394, Thomas 118). ${ }^{19}$ Further, notions of white slavery fueled other national anxieties including growing numbers of unmarried women, urbanization, economic concerns, and the consolidation of corporate conglomerates (Haylock 64).

In the Western imagination, depictions of the harem were associated with discourses on slavery and sex. In certain contexts, the Muslim harem system was often built upon the system of slavery (DelPlato 19). Conversely, as Sarah Graham-Brown and Reina Lewis's work shows, harems were not always (or even often) Wharton's "smoldering prison"; rather, harems were 
often dynamic social spaces and sites of female society with its own internal power structures. This image of the domestic harem, more like a Western drawing room as opposed to a brothel, was not what most Americans had in mind when they conjured within fantasies of American Orientalism. At any rate, as Joan DelPlato suggests, Western depictions of the harem were almost always self-referential. Burrowing from Foucault's work on Victorian sexuality, DelPlato argues that "typical of the nineteenth-century discourse on 'deviant' sexualities, the harem is understood in reference to the speaker's 'normal' sexuality. In binary fashion, eastern sexual and social experience constructs western sexual and social experience" $(26) .{ }^{20}$ In addition to gender and sexuality, the harem marked racial difference as well. As elsewhere in In Morocco, Wharton describes a racial hierarchy within the harem. The "negresses" are those in a servile positions, while Arabs, who Wharton names "the Sultan's favorites," are of a higher distinction (88).

Wharton does more than merely argue for the rights of women secluded in harems. She uses the harem to further build her argument about the dangers of unchecked Islam to one's sense of national identity. Judith Funston argues that Wharton "felt horror at the situation of the harem" (18). The horror that Wharton experiences is primarily the result of her experience with one woman at the harem. Wharton describes "a rosy fair-haired girl, dressed in Arab costume, but evidently of European birth" (In Morocco 93). The reader learns that this young lady's mother was French and that she is an "intimate friend of the ladies of the household" (In Morocco 93). Wharton is intrigued by a woman with Western European origins who is dressed in "Arab costume" affiliated with the harem. Wharton notices that "the fair-haired girl" is never allowed to speak in the harem under the watchful eye of a "vigilant guard" (In Morocco 94). Wharton takes it upon herself to question the woman (in French). She asks, "So your mother is French, Mademoiselle? From what part of France did she come?" (In Morocco 94). When the 
woman cannot answer the question in French and then says that her mother comes from "the Switzerland" part of France, Wharton concludes that, "The poor girl could not speak only a few words of her mother's tongue. She had kept the European features and complexion, but her soul was the soul of Islam" (In Morocco 94). Wharton suggests that perhaps the real horror is not the bloodshed of the rituals, or the proximity between life and death, but it is rather the ability of Islam to convert a young (white) woman's national, racial, and religious identification. Wharton concludes her meeting with the French woman by noting that Islam had placed its "powerful imprint upon her, and she looked at me with the same remote and passive eyes as the daughters of the house" (In Morocco 94).

For Wharton, the racial underpinning of harem slavery is disrupted by the presence of the white "French" harem girl. So, while Wharton is disturbed by the gender and sexual politics of the harem, it is only when she encounters the "French" harem girl that Wharton is truly terrified. Wharton's horror at seeing a "white" harem woman reflects the fear/fantasy of white sexual slavery. Since the times of the Barbary captivity narratives, stories of "white slaves" held by Muslim "masters" circulated in the West. Reina Lewis explains that white slaves did exist in Muslim harems: "Slaves, mainly women, from the Caucasus regions of Georgia and Circassia were very important to the harem slave trade, but also gained the attention of the West for whom the prospect of 'white' slavery was particularly troubling" (132). White woman held "a special positon in domestic slavery, being legendary for their pale beauty and much sought after for elite harems and the palace" (Lewis 132). Stories of white women enslaved in harems took on mythological status and even became a rallying point for arguments against slavery and prostitution in the Britain and the United States during the mid-nineteenth century. 
Since harems were typically discussed as a racialized space, and as diametrically opposed to Western styles of marriage and monogamy, Wharton's encounter with the "French" girl has a destabilizing effect. Wharton is terrified by the collapse of difference between herself and the "French" harem girl. The harem girl simply does not fit within Wharton's racial classification or understanding of the racial hierarchy so prevalent in the United States. In other words, the "French" girl is a ghastly double as her outward appearance in is white/Western and her "soul is the soul of Islam." Wharton does more than merely argue for the rights of women secluded in harems. She uses the harem to further build her argument about the dangers of unchecked Islam to one's sense of national identity.

Ultimately, the "French" harem girl not only suggests the fear/fantasy of white enslavement but it also "arouses the terrible specter of miscegenation" (Grewal 47). For Wharton, this all suggests that women (regardless of racial of religious status) are potential victims of the Islamic institution of the harem. As Wharton notes, "Respectability wears the same face in an Oriental harem as in England or America" (In Morocco 94). In the end, for Wharton the terrors of the harem are tied back to a social system structured by the persistence and evils of Islam.

Though Wharton offers her sympathy to the black Moroccans (like participants in the ritual), she also dismisses these participants as subhuman or bare life. The half-French girl from the harem receives gentler treatment but is still used as a symbol of Islam's destructive tendencies. It remains ironic that Wharton criticizes Islamic violence as she participates in her own form of epistemic violence by portraying Islam as an essentially barbaric religion consumed with violence and death. Wharton identifies the Moroccan landscape and people as the living dead, while she characterizes Islam as the epitome of living death. Taken together, Wharton's 
assessments of Morocco generally and Islam specifically reflect Goldberg's assertion that within Western imaginaries Islam is associated with a lack of freedom and life (165). This lack, then, becomes affiliated with a "renunciation of the values of life" and of "life itself" (Goldberg 165). Wharton's In Morocco continues this historical discourse wherein "the Muslim stands for the European... as the figure of death's approach, death walking, the plague" (Goldberg 165). Wharton perpetuates this discourse by presenting the harem as the ultimate space of lack-the lack of women's rights, and, for the French girl, the lack of national identity.

I've maintained that Wharton's rendering of Islam throughout In Morocco is indicative of a wider anti-Islamic sentiment prevalent in the turn-of-the-century United States. At first glance it may be difficult to appreciate what influence Morocco, a French colony, had on the United States. From a global or transnational perspective, we can see that French Morocco did impact the U.S. Even Wharton notes that the two countries were closer than what a reader may initially think. Wharton acknowledges the transnational relationship between the U.S. and Morocco as she considers the "acres and acres of graves [that] fall away from the red ramparts to the grey sea; the breakers rolling straight from America to cast their spray across the lowest stone" (In Morocco 17). This passage alludes to the flow of transnational influence from America to Morocco and in reverse. For instance, Wharton's problematic conflation of race and religion was evident in U.S. immigration law. At the time Wharton traveled to Morocco, "Arab" was used to refer to any number of things, including a homeless child, a street vendor, any person of "mixed breed," any dark complexioned person, and so on (Rama Berman 17). The national origin of Arabs was not easy to identify either. "Arab" could refer to those who were Turkish or had a Central European or Middle Eastern origin. Therefore, there was general confusion as to what/who constituted an Arab in the U.S. Islam was not always necessarily equated with Arabs 
as it is in Wharton's travel guide. But the equation of Arab, non-white, and Islam was nonetheless a popular assumption in the United States (up to present day). In Morocco contributed to the general process of racialization where Islam became "a generic signifier used to single out the Moslem for its 'irrational, morally inferior, and barbaric masculinity and its passive victimized, and submissive femininity"' (Moallem 322). Given the context, it is no wonder so many "Arabs" immigrating to the United States felt the social and legal pressures of assimilation and religious conversion (Suhair Majaj 329). Through the language of death, Wharton found an ideal way to express her distaste for Islam in a way that would resonate with a Western reading audience already trained to consider Islam as a symbol of lack and death.

One should not underestimate the role of the turn-of-the-century guide book in propagating anit-Islamic content and the subsequent racialization of Muslims in the West. As Said points out in his landmark text Orientalism, orientalist conceptions of the other started far earlier than Wharton's time. It is equally safe to say that it has continued long after Wharton wrote In Morocco. Despite the assertions that the racial profiling of Arabs began primarily following 9/11, In Morocco shows that the process of racialization in regards to Islam was already firmly rooted as part of the U.S. national consciousness over a century ago. Of course, the Bush administration's War on Terror caused significant increases in the racial profiling of Arabs (Goldberg 96). More now than any time in recent historical memory, Arabs living within the United States are configured as "present-day pariahs" who are subject to "state-mandated racial profiling" (Goldberg 96). Currently, images of Islamic fanaticism and violence dominate Western media, thus perpetuating the over-simplified and long-standing image of a civilized (Christian) West in battle with a barbaric and apocalyptic (Islamic) East. Images of public beheadings of Western journalists at the hands of Islamic radicals play on major media networks. 
Like early twentieth century concerns over the "Moslem menace," the media proliferates reports of U.S. intelligence agencies on the hunt for "secret" Muslim "terrorists" living in the United States or, worse, U.S. citizens who have converted and are committed to the jihadist cause. The media has replaced reports of "white slavery" with reports of the white "brides of ISIS." 21 Considering the current socio-political climate, along with the United States' precarious relationship with the Islamic world, texts like Wharton's deserve careful reconsideration. 


\section{Conclusion: Moving Forward}

In her work on Edith Wharton's conservative racial politics, Jennie Kassanoff laments her difficulty in writing about Wharton's racism. The impulse, at least in Wharton studies and perhaps scholarly discourse more generally, has been to avoid the issue of race all together or to "forgive" Wharton's racism as simply a "product of the time." Perhaps the latter approach is even more damaging than the former in that it leaves un-interrogated the machinations of white supremacy that defined and continue to define U.S. political and social culture. In this project I have sought, instead, to interrogate the relationship between the politics of gender and the politics of race for white women journalists and travel writers writing about U.S. imperialism at the turn-of-the-twentieth century. Demonstrating that their gender politics were inseparable from their racial politics, I've worked to advance studies of women's involvement in U.S. imperialism. In general, these women had few qualms about asserting racial superiority in their fight for (white) women's rights, whether at the expense of African American or Native American women at home or colonized others abroad. But rather than bury these texts as unsightly reminders of a racist past, I've recovered the work of Hamm, Krout, Bly, and Wharton in hopes of answering Hazel Carby's call for "more feminist work that interrogates sexual ideologies for their racial specifics and acknowledges whiteness, not just blackness, as racial categorization" (16). Although it is not the current critical trend to "recover" work that represents hegemonic discourse (as if it somehow implicitly reproduces the discourse it interrogates), the travel writing that I examine disrupted hegemonic patriarchy even as it perpetuated white privilege and supported U.S. imperialism to varying degrees. In fact, these writers used the imperial context to advocate for the rights of women. Thus, the vectors of power 
and hegemony intersect instructively. Hamm, Krout, Bly, and Wharton demonstrate how white women negotiated the discourse of expansion for their own interests.

While my work on Hamm, Krout, Bly, and Wharton has helped lay the foundation for thinking about dominant U.S. cultural attitudes regarding gender, race, and imperialism in the late-nineteenth and early-twentieth centuries, the next step is to consider their works in conversation with other women who perhaps didn't share their enthusiasm for empire, their privileged racial status, or their national affiliation. Moving forward, I'm guided by questions such as how did women outside of the dominant culture negotiate and experience travel and empire? How did their strategies regarding the nexuses of race, gender, and nation shift compared to those examined here?

Mable Craft provides an alternative narrative of U.S. imperialism that differs from many of her contemporaries. Also a newspaper woman and foreign correspondent, Craft wrote for the San Francisco Chronicle and traveled extensively. ${ }^{1}$ Not without some of her own racial prejudices, Craft was nonetheless one of the few white suffragists to dispute the "color line" imposed in women's social clubs and organizations. ${ }^{2}$ Craft brought this racial sensibility with her as she traveled to Hawaii for the San Francisco Chronicle in 1898. Unlike Krout and Hamm, Craft strongly objected to U.S. annexation of Hawaii (and the Philippines) and combined her progressive racial and gender politics to argue against U.S. expansion. In 1899 she wrote a travel guide, Hawaii Nei, wherein she dismantled the logics of U.S. imperialism in Hawaii-along with reversing the racist assumptions that underpinned such logics. ${ }^{3}$ In Hawaii Nei, Craft provides a "corrective" account of U.S. annexation on geographical, political, economic, religious, and cultural grounds. She rebukes the political justification for annexation, namely that annexation was replacing a "savage" Hawaiian monarchy with a "civilized" territorial government. Craft 
offers a contrasting narrative wherein she explains the "civilizing" motives of the "millionaire missionaries" and critiques the "prevailing idea that lurks under white skins, that the AngloSaxon civilization is the only one worth having" (19). Craft surmises that when the missionaries taught native Hawaiians a new religion, "they should also have taught them how to maintain themselves in the throat-cutting civilization of the Anglo-Saxon" (18).

Craft disrupts the popular belief that Hawaiian women were victimized by native men under native religious practices. While acknowledging the harshness of tribal laws, Craft nonetheless maintains that "there was one equal standard of morality" among native women and men (76). Craft explains that "domestic duties were shared" between men and women that practices like polygamy (a typical example of Hawaiian barbarism) didn’t apply solely to men. For instance, as Craft explains, while it is true that chiefs took multiple wives, it also true that when there was a female chief, she took multiple husbands. Based upon these examples and others, Craft asserts that "if the position of women is to be taken as a criterion of civilization, the Hawaiians were not so low in the scale" (76). She takes this a step further and concludes, "In the matter of sex equality, Hawaii could give some points to some of her more civilized sisters" (189). Craft's Hawaii Nei represents just one counter-narrative to the gendered and racialized discourse U.S. imperialism. While her view represents a minority opinion she certainly wasn't alone in her anti-imperialist sentiment. As progressive as her writing appears alongside that of Mary Krout or Margherita Hamm, Craft is still a product of white privilege even as she challenges the discourses of civilization and white supremacy.

In addition to anti-imperialist writing, it is necessary to consider the ways in which African American women writers and travelers negotiated and responded to U.S. imperialism and expansion. Important recent works like Gretchen Murphy's Shadowing the White Man's 
Burden (2010) and John Cullen Gruesser's The Empire Abroad and the Empire at Home (2012) both consider the responses of African American writers to U.S. imperial ambitions at the turn into the twentieth century. ${ }^{4}$ Beyond this work, we need to consider how African American women negotiated their race and gender status as it related to travel and empire. Carlotta Stewart Lai was one such African American woman who spent her adult life living and working in Hawaii as a teacher and school administrator. ${ }^{5}$ Unlike Krout and Hamm who published their writings, Stewart Lai's archive is comprised of personal letters that she sent to the mainland during her time in Hawaii (her letters are held at Howard University Library). Her letters provide one of the few available accounts of African American women's experiences in U.S. held territories at this time. Specifically, her experiences demonstrate that black women could achieve a comfortable middle-class status in Hawaii while simultaneously experiencing similar racial prejudices as those in the States.

For a truly transnational understanding of U.S. imperialism, in addition to studying accounts of non-white U.S. women, we need also to consider the perspective of women from the territories dominated by the U.S. Along these lines, in the next stage of this project I plan to examine the life and work of Clemencia Lopez, the Filipina who addressed the New England Women's Suffrage Association in 1902 in an attempt to convince her "sisters in the States" of the atrocities of the U.S. occupation and colonization of the Philippines. Lopez lobbied against U.S. imperialism and personally experienced some of its most devastating effects. Beyond the speech given in the Washington D.C. in 1902, Lopez wrote extensively on U.S. colonization, yet there remains little academic scholarship on her work. ${ }^{6}$ Work like Lopez's provides tremendous insight into strategies of resistance deployed by women who had a vastly different relationship to the structures of U.S. imperialism. 
For every Margherita Hamm, Carlotta Stewart Lai, Mabel Craft, and Clemencia Lopez there are dozens (if not hundreds) more that remain buried deep within the archives. Studying them can yield a more nuanced picture of women's involvement in U.S. imperialism. 
Notes

Chapter 1

\begin{abstract}
${ }^{1}$ According to John Eperjesi, imperialist imaginary refers to a "moment in which a particular representation, or misrepresentation, of a geographical space supports the expansion of the nation's political and economic borders" (2). Key to this formulation is that "the imperialist imaginary produces the region that it takes as its geographical foundation" (Eperjesi 4).
\end{abstract}

${ }^{2}$ A note on terms: I typically use "U.S. women" and "U.S. imperialism" rather than "American women" or "American imperialism" in an effort toward geopolitical specificity and to avoid the totalizing use of "America/American" to only refer to the U.S., thus eliding the rest of the American continent.

${ }^{3}$ Most discussions of the racial dynamics of imperialism are indebted to Edward Said's foundational formulation of Orientalism. In 1979, Said defined Orientalism as "a style of thought based upon ontological and epistemological distinction made between 'the Orient' and... 'the Occident"” (Orientalism 5). "The phenomenon of Orientalism," Said continues, "deals principally, not with a correspondence between Orientalism and Orient, but with the internal consistency of Orientalism and its ideas about the Orient ... despite or beyond any correspondence, or lack thereof, with a 'real' Orient" (Orientalism 5). Orientalist representations projected the East as a monolithic, subordinate, feminized, and racially "other," compared with a racially superior, rational, strong, and masculine West.

${ }^{4}$ To this end, postcolonial and feminist theorists have approached the symbolic and material role of white women in the colonial project from a variety of angles. Influential recent work by feminist scholars Anne McClintock, Laura Wexler, Jenny Sharpe, Jane Higgins, and Vern Ware explore white Victorian women's often ambivalent role as boundary markers between the 
domestic and the foreign, or how women domesticated colonial space. As more scholars examine the role of white women in empire, theorists, such as Trinh T. Minh-ha, Gayatri Spivak, and Chandra Mohanty have critiqued Western feminist work that continues to ignore white women's complicity in imperialism. I share Sharpe's call for nuanced intersectional analysis of race and gender. As she explains, "the task is not to resolve the problems of white femininity by mapping race onto gender but to maintain those problems as sites of textual and theoretical production" (11).

${ }^{5}$ There are a handful of exceptions to this trend including the scholarship by Amy Kaplan and Laura Wexler among others.

${ }^{6}$ In her study of late nineteenth century women journalists, Alice Fahs argues that most studies of U.S. women and journalism focus on mid-nineteenth century journalists, such as Fanny Fern, rather than the work of women entering the newspaper business at the end of the nineteenth century (8).

${ }^{7}$ Taketani examines women's antebellum children's geography primers as "school textbooks [that] worked in conjunction with the formation and subversion of colonialism" (39).

${ }^{8}$ This quote is taken from an article that appeared in The World on March 8, 1896. The headline and caption read: "Nellie Bly Fin de Siecle Joan of Arc: Nellie Bly Proposes to Fight for Cuba" (Kroeger 288).

${ }^{9}$ It had become increasingly clear by 1890 that the National American Woman Suffrage Association (NAWSA) had no intention of making black women's votes part of their agenda. One reason was most likely due to the NAWSA's alliance with Southern women's temperance groups who joined suffrage efforts only under the condition that the vote be reserved for white women only. Additionally, Louise Newman argues that "the possibility of interracial cooperation 
between the struggles for civil rights and women's rights was diminished in the 1870s and 1880s... when black men received the franchise ahead of them [white women]" (4).

${ }^{10}$ A particularly illustrative example of the racial tension within the women's movement was a public argument over lynching between Ida B. Wells and Mary Krout, which played out in the Chicago Daily Inter Ocean. Reporting from London, Krout sent a dispatch to the Inter Ocean titled "The Negro is Discussed" wherein she criticized an anti-lynching lecture delivered by "Mr. Williams, a colored man" (qtd. in Fahs 266). Krout complained that Mr. Williams "made no discrimination whatever between the North and the South" and that there "were glaring inaccuracies of grammar and punctuation" throughout the lecture (qtd. in Fahs 265). Well-known for her activity in the anti-lynching movement, Wells responded to Krout with a letter to the Inter Ocean. In the letter, Wells argued against Krout point by point. Wells argued that "Miss Krout is grievously in error when she states that 'throughout the North everything has been done for the Negro that could be done"' (qtd. in Fahs 267). In response to Krout's criticism of Mr. Wells' grammar, Wells wrote, "glaring inaccuracies of grammar and punctuation was generally a misfortune, rather than a fault, when it known that the negro's parents, through circumstances over which they have no control, were deprived of liberty, and the fruits of their labor went for the education of the white offspring of their masters" (qtd. in Fahs 266) ${ }^{10}$ Krout's (mis)understanding of racial history, and Wells's response, demonstrates the tension that existed among black and white women committed to their own images of social justice.

${ }^{11}$ The 1875 Supreme Court Case Minor v. Happersett ruled that suffrage was a state's rights issue not a federal/national issue. However, U.S. expansion—westward continental expansion in the 1870s and 1880s and extra-continental expansion in the 1890s — made suffrage a national issue and not merely a states' rights issue. Many suffragists sought a constitutional amendment 
allowing for women's suffrage as opposed to the current states' rights approach. The states' rights approach to suffrage had disastrous consequences for not only women, but for many black U.S. citizens.

${ }^{12}$ Wharton referred to herself as a "rabid imperialist" in a March 1901 letter to Sara Norton.

${ }^{13}$ Kaplan challenges the dominant narrative regarding the political participation and significance of those domestic women considered examples of True Womanhood during the Westward expansion of the United States. Rather than being non-participatory, Kaplan maintains that these women were essential in the demarcating the domestic from the foreign within discussions of manifest destiny and expansion during the mid-nineteenth century (Anarchy 24-25).

${ }^{14}$ The New Woman and Bachelor Girl are just two of several terms assigned to women who desired participation in the public sphere. Others included "business girl" and "working girl," though these had vastly different connotations than New Woman or Bachelor Girl. For information regarding the distinction between these labels as they were expressed in U.S. newspapers see Alice Fahs's Out on Assignment: Newspaper Women and the Making of Public Space (2011). 


\section{Chapter Two}

1 “Treasure Island of the Pacific" is from Hamm's chapter title "The Philippines, or the Treasure Islands of the Pacific" in America's New Possessions and Spheres of Influence (1899).

${ }^{2}$ Lopez's address was printed in the Boston-based Woman's Journal on Saturday, June 7, 1902. The speech was delivered earlier that year in May. Between Lopez's address and its subsequent publication, the Philippine-American War was declared over on July 4, 1902, though fighting continued through 1913. Lopez was part of an active revolutionary Filipino family who fought first against Spanish control, then against the U.S. occupation. She traveled to the United States to plead for the release of her brother, Sixto Lopez, from banishment to Talim Island. After her visit, she became affiliated with the Anti-Imperialist League. While in the U.S., Lopez became the first Filipina to enter the White House where she met President Roosevelt. Eventually she returned to the Philippines were she founded the Philippine Feminist Association in 1905. She died in 1965. Overall, Lopez has been left out of discussions pertaining to all aspects of Philippine-American relations. All biographical information came from the website Positively Filipino: Your Window on the Filipino Diaspora:

(http://www.positivelyfilipino.com/magazine/2013/3/clemencia-lopez-independista)

${ }^{3}$ This article was an opinion piece authored by Frank Carpenter wherein he considers viable women for the U.S. Congress.

${ }^{4}$ In 1893 Hamm married William Fales, a New York-based lawyer and newspaperman. In the only available academic study of Hamm's life, Alice Fahs describes Fales as “a bohemian of the old school, a man about town" (251). Hamm and Fales divorced in 1902.

${ }^{5}$ For additional information on the Spanish American war and the Philippine American war see Kristin Hoganson's Fighting for American: How Gender Politics Provoked the Spanish- 
American and Philippine-American War (1998), Stanley Karnow's In Our Image: America's Empire in the Philippines (1990), and Stuart Creighton's Benevolent Assimilation: The American Conquest of the Philippines 1899-1903 (1984).

${ }^{6}$ President William McKinley issued the Benevolent Assimilation Proclamation on December $21^{\text {st }}, 1898$, which outlined his plan for pacifying and managing the Philippines. The plan was announced by Major General Elwell S. Otis in the Philippines on January 4, 1899. Emilio Aguinaldo composed an oppositional response to Otis's proclamation, which appeared in the $E l$ Herlado De la Revolucion, the official newspaper of the Philippine government.

${ }^{7}$ Hamm literally wrote hundreds of pieces for various newspapers including the New York Journal, Current Literature, The Boston Globe, and Pearson's Magazine. The majority of these articles have not been archived, though a few have. In addition to Manila and the Philippines and America's Possessions and Spheres of Influence, Hamm wrote a book-length account of Puerto Rico titled Porto Rico and the West Indies. She also wrote a biography of Admiral Dewey Dewey the Defender. She is probably best known today for her historical text First Families of New York, which was a volume tracing New York's most prominent families. She also published a collection of short stories about the lower east side of New York, Ghetto Silhouettes, along with several short stories about the "Egyptian Colony" of New York in Pearson's Magazine. Hamm published poetry occasionally, including an ode to Elizabeth Cady Stanton.

${ }^{8}$ The sheer breadth of Hamm's America's New Possessions and Spheres of Influence is impressive. A full list of the locations she discusses includes: Alaska, the Aleutian Islands, Hawaii, Puerto Rico, the Philippines, Mariana Islands, Samoa, Wake Island, Navassa, Cuba, Nicaragua, Mexico, China, Japan, Jamaica, the Bahamas, and the Danish West Indies. 
${ }^{9}$ When Hamm traveled to the Philippines in 1898 , there was not a large population of American women present. In the years following the Spanish-American War, some American women did permanently live in the Philippines. Many were teachers or missionaries, along with journalists and travel writers. For example, over 150 American women traveled with the Thomasites in 1901 as teachers in the American schools in the Philippines. Additionally, the wives of military businessmen and investors also made the Philippines home. Stanley Karnow notes that by the first decade of the twentieth century, "American women in Manila largely set standards. Like the memsahibs of India, they were determined to preserve their code of conduct in a foreign landwhich did not include social ties with the natives, regardless of rank" (Karnow 563).

${ }^{10}$ Livermore was a well-known reformer who served as the president of the Massachusetts Woman Suffrage Association. She also worked as the pro-suffrage editor for the Woman's Journal.

11 The U.S. army regulated and managed prostitution in the Philippines through medical inspections of prostitutes and licensure. Medical inspections and licensure were both mandatory, and put in place by the U.S. army to control the spread of venereal disease among U.S. servicemen. Ian Tyrrell explains that the army's "answer" to the demand for reform "was not the eradication of world's oldest profession, but closer regulation to improve military health....Suspected prostitutes were to be examined weekly and issued certificates of clean health" (137). If a woman was found to be "infected," then she was sent to a "specially designated hospital" (Tyrrell 137). For more on moral reform and prostitution in the Philippines see Ian Tyrrell's Reforming the World: The Creation of America's Moral Empire (2013). ${ }^{12}$ Nerissa S. Balce discusses race and gender in her work on colonial intimacy. Balce examines the American production of the colonized Filipino woman in U.S. popular culture through the 
Bebell 173

image of bare breasts, which continued to create and propagate the image of the Filipino savage in need of saving by the benevolent U.S. 


\section{Chapter Three}

"The "Hawaiian Revolution" was the name assigned to the forceful U.S. overthrow of the Hawaiian monarchy in 1893, thus solidifying U.S. political control over the Islands. Formal annexation came in 1898 following the Newlands Resolution that assigned Hawaii the status of "unincorporated territory." The Resolution denied Hawaii the advantages of U.S. statehood and withheld U.S. citizenship to Hawaiians. The U.S. did not grant Hawaii statehood until 1959. ${ }^{2}$ After much political debate, The House of Representatives passed the joint resolution on June 15, 1898 to officially annex the Hawaiian Islands. The resolution gained Senate approval on July 6, 1898. The resolution passed with a significant margin. In the House of Representatives, the vote was in favor 209 to 91 . In the Senate, the vote was 43 to 21 (on the day of the vote 26 Senators were absent from the session, despite the importance of the vote) (Love 156). ${ }^{3}$ Alice's Visit to the Hawaiian Islands was published by the American Book Company (ABC) and marketed as a "geography primer." It was published as part of the ABC's collection of "Eclectic School Readings" intended for home and classroom use (Dail 1). As it was originally produced, Alice's Visit was a small and portable volume with photographs taken by New-York based photographer C.C. Langhill. Langhill was hired by the Charles Skinner, the State Superintendent of New York, to take photographs of Hawaii for educational purposes so that it could be incorporated into New York's school curriculum (Skinner 275). The images were available for use when Krout compiled the primer.

${ }^{4}$ There are some provocative studies of the intersection between children's literacy practices and imperialism. See Roderick McGillis’s A Little Princess: Gender and Empire (1996); Rashna B. Singh's Godly is Our Heritage: Children's Literature, Empire, and the Certitude of Character 
(2004); Voices of the Other: Children's Literature and the Postcolonial Context, an edited collection by Roderick McGillis (1999); and Perry Nodelman's essay “The Other: Orientalism, Colonialism, and Children's Literature" (1992).

${ }^{5}$ Primers in the Colonial and Early National periods were usually focused on religious or spiritual instruction for children. For more information on primers in this period, see Veronica Schanoes's "Fearless Children and Fabulous Monsters." Marvels and Tales 26.1 (2012): 30-44; see also Johanna M. Smith's “Constructing the Nation: Eighteenth-Century Geographies for Children." Mosaic: A Journal for the Interdisciplinary Study of Literature 34.2 (2001): 133-149. ${ }^{6}$ The sales materials contained within Alice's Visit advertise other geographies that seem, based upon the title, to have an international focus. For instance, one text advertised is Australia, Our Colonies, and Other Islands of the Seas.

${ }^{7}$ Geography as a science and discipline during the $19^{\text {th }}$ century was undergoing major changes, including the development of clubs and societies dedicated to the study of geography like the National Geography Society founded in 1887 . The discipline of geography was becoming widely studied in the academy and was closely connected to the field of cartography (Michie and Thomas 2).

${ }^{8}$ For more on feminist geography see the edited collection Writing Women and Space: Colonial and Postcolonial Geographies (1994).

${ }^{9}$ Not much is known about Krout's early life beyond what is listed in short entries in a handful of reference books, such as Who's Who, and books dedicated to notable citizens of Indiana. What is known is that Krout was born sometime around 1852 in Crawfordsville, Indiana. Limited biographical information is available in Zach's Crawfordsville: Athens of Indiana (2003), Fahs's Out on Assignment (2011), and Schriber's Writing Home (1997). 
${ }^{10}$ Many Americans argued against the U.S. annexation of the Hawaii and the Philippines. Many who argued against imperialism (known by the label anti-Imperialist) cited "race" as a primary reason not to annex locales occupied by non-white others. For more regarding how race placed limits on U.S. expansion see Eric T. Love's Race Over Empire (2004).

${ }^{11}$ For additional information on U.S. Americans living in Hawaii during the 1890s and early twentieth century see Judy Rohrer's Haoles in Hawaii. Honolulu: University of Hawaii Press, 2007.

12 The status of "incorporated" verses "unincorporated" territory was decided in a series of 1901 Supreme Court decision known as the Insular Cases. For additional information on the Insular Cases see Bartholomew Sparrow's The Insular Cases and the Emergence of American Empire. Lawrence, Kansas: University of Kanas Press, 2006. See also Gerald Neuman and J. Sinclair Armstrong's Reconsidering the Insular Cases: The Past and Future of American Empire. Cambridge: Harvard UP, 2015.

${ }^{13}$ For additional information on the masculine rhetoric of U.S. empire-building see Gail Bederman's Manliness and Civilization: A Cultural History of Gender and Race in the United States, 1880-1917 (1996) and Kristin Hoganson's Fighting for American Manhood: How Gender Politics Provoked the Spanish-American and Philippine-America Wars (2000).

${ }^{14}$ For additional information on American girlhood in the nineteenth century see Melanie Dawson's “The Miniaturizing of Girlhood: Nineteenth-Century Playtime and Gendered Theories of Development” in The American Child: A Cultural Studies Reader (2003).

${ }^{15}$ Anti-Chinese sentiment in the U.S. was typified in the passage of several Immigration Acts, which placed strict immigration quotas on Asian and European immigrants. Specifically, the Chinese Exclusion Act (1882) prohibited the immigration of Chinese laborers to the United 
States. For additional information see Lisa Lowe's Immigrant Acts: On Asian American Cultural Politics (1996).

${ }^{16}$ The realities of the sugar cane industry in Hawaii in 1900 were far harsher than what Krout describes. The industry was tightly controlled by a wealthy, white American planter class ("The Big Five"), which dominated the sugar trade. Sugar plantations, owned by American businessmen, greatly changed the landscape of Hawaii and in the process displaced native Hawaiians from their homes (Kauanui 69). The most viable land was "ceded" to the U.S. at the time of annexation in 1898, thus making the land "public lands of the colonial territory" (Kauanui 79).

${ }^{17}$ The Appeal was written by Elizabeth Cady Stanton and contained several signatures of prominent suffragists. Krout's name does not appear on the petition. For additional information on the Hawaiian Appeal see Allison Snider's Suffragists in an Imperial Age: U.S. Expansion and the Woman Question, 1870-1920 (2008).

${ }^{18}$ For additional information on "hula circuits" see Adria Imada's essay "Hawaiians on Tour: Hula Circuits through the American Empire." American Quarterly 56.1 (2004): 111-149. 


\section{Chapter Four}

${ }^{1}$ The Google doodle animation was created by Katy Wu (http:www.google.com/doodles/Nellieblys- $151^{\text {st }}$-birthday).

${ }^{2}$ Following the Google banner, there was a short but robust media blitz regarding Bly's life and work. Many popular news sources published short biographies on Bly following the Google doodle, including The Huffington Post, CNN, Time, ABC, and The Washington Post. This was likely the most "visibility" Bly had since she fell out of cultural / popular memory sometime around the 1930s.

${ }^{3}$ For more information on Bly's trip around the world see Matthew Goodman's Eighty Days: Nellie Bly and Elizabeth Bisland's History-Making Race Around the World (2013). Goodman tracks Bly's competition with Elizabeth Bisland. In an effort to increase readership, Bisland was employed by The Cosmopolitan magazine to "race" Bly around the world.

${ }^{4}$ Cochrane took the pen name Nellie Bly (though misspelled) after the song of the same name by Stephan Foster. The name was not chosen by Bly, though she didn't object to it. It was suggested by her editor and mostly male co-workers at the Pittsburgh Dispatch.

${ }^{5}$ Wilson's article for the Pittsburgh Dispatch was titled "Anxious Father," and it was published in January 14, 1885. Despite the difference in their attitudes toward gender, Wilson and Bly became life-long friends (Lutes 315).

${ }^{6}$ Bly's "Girl Puzzle" is quoted from Maureen Corrigan and Jean Marie Lutes's collection Nellie Bly: Around the World in Seventy-Two Days and Other Writings (2014). The recent publication of this volume suggests increased interest in the work and life of Nellie Bly. 
${ }^{7}$ Kroeger speculates that a reason for Bly's absence within academic source materials is due to her rather sudden death. She didn’t leave any papers, records, or letters prior to her death. So, most of what is known about Bly has been painstakingly cobbled together from various sources. 8 "Girl stunt reporting" was a popular subgenre of journalism during the final decade of the nineteenth century. This type of reporting, where the reporter would go "undercover," had a highly performative aspect. Stunt reporting often covered "human interest stories. Stunt reporting was used to discuss factory conditions, opium dens, illegal abortion hospitals, and, in Bly's case, an asylum. Bly wasn't the only girl stunt reporter at this time, but was likely the best-known. ${ }^{9}$ Hamm disliked all sensational news in favor of what she deemed serious reporting, but she wasn't always so critical of Bly. Following a public fall-out between Bly and the New York World, Hamm came to Bly's defense in the press. Writing for The Journalist in 1891, Hamm acknowledged that Bly had been treated badly by the paper and experienced "much unnecessary suffering." Hamm continued, "Miss. Bly is always faithful, authentic and clear in her work...and she certainly accomplished what no other woman has been able to do." Bly "deserved a great deal of credit...for her detective work," concedes Hamm. Hamm held World accountable for their "mistreatment" of Bly in the years following her trip around the world ("Pleasure Trip to Europe" The Journalist Dec. 19, 1891, 9.4. qtd. in Kroeger 191).

${ }^{10}$ It is possible, even probable, that other U.S. newspapers "picked up" Bly's articles from The Dispatch. The full extent to which this occurred is unknown, but Kroeger reports that at least one dispatch (from March 22, 1886) was picked up by The St. Louis Globe-Democrat. It was this article, published in the Globe-Democrat, which found its way back to Mexico City, thus alerting Mexican authorities to Bly's criticisms of the Mexican government (Kroeger 70). 
${ }^{11}$ In the aftermath Mexican American war of 1848, the U.S. acquired more territory from Mexico than it had acquired from the Louisiana Purchase. In the 1840s, there was even an intense "all Mexico" debate wherein U.S. politicians debated the merits of annexing the entire country (Nugent 208). The all Mexico plan was indeed disregarded, but the U.S. has acquired all of upper- California, Texas, and New Mexico following the Mexican American war. President Polk gained public support for the Mexican American war by using the language of manifest destiny to legitimate and justify an armed conflict with Mexico.

${ }^{12}$ Margherita Hamm offered her vision for the future of Mexico in America's New Possessions and Spheres of Influence (1899). Hamm predicted that since "the policy of Mexico is that of extreme friendship toward the United States" then it only made sense that Mexico would soon "pass under the Stars and Stripes" (221). Even if the United States didn’t annex Mexico, Hamm felt certain that Mexico’s “coming development will be achieved largely if not exclusively by American capital and American enterprise" (221).

${ }^{13}$ Many assume that that the All Mexico debate had dissipated by the late nineteenth century, and, for the most part, it had. Yet, in the 1880s, there remained interest in annexing additional Mexican territory among members of the U.S. Congress and State Department. In 1891, a resolution was presented by New York's Senator Matt Quay to the U.S. Committee on Foreign Relations that argued for the territorial annexation of a large part of Northern Mexico. The resolution posed the following question: "whether the acquisition of those portions of the state of Sonora, Chihuahua and Coahuila...in the Republic of Mexico, is practicable and for the interest of United States" (Congressional Record 23.47). The resolution was rejected. Objectors claimed that it was better that Mexico keep its independence to avoid the problem of incorporating Mexican people into U.S. social and political culture. 
${ }^{14}$ Specifically, Gilbert González defines the "Mexico problem" as the "sum total of the cultural and character 'defects' that distinguished Mexicans from the Anglo-Saxon or American norm" (10). As an article published in an 1873 edition of the Overland Monthly further articulates the "Mexican problem" in terms of power inequities between the U.S. and Mexico: "the policy of the U.S. toward Mexico is considered as the attitude of a great and prosperous nation to a weak and bankrupt one" (63). The article continues and identifies those with stakes in settling the Mexico question, including "the interests of American citizens in Mexico, of American commerce, and the residents of the United States living near the border" (63).

${ }^{15}$ These quotes are taken from Donald Trump's June 16, 2015 presidential announcement. The full text and video can be found at: http://time.com/3923128/donald-trump-announcementspeech/ 


\section{Chapter Five}

${ }^{1}$ According to the Oxford English Dictionary, bled is defined as: "In parts of North Africa formerly under French rule: an uncultivated wasteland; the hinterland behind a fertile, populated area"(http://www.oed.com.www.libproxy.wvu.edu/view/Entry/20092?rskey=vKfCcE\&result=1 \&isAdvanced=false\#eid).

${ }^{2}$ The 1912 Treaty of Fez established Morocco as a French "protectorate" (Spain received a portion of northern Morocco). The Alwai dynasty remained as "figurehead" Sultans, but a "French resident general controlled affairs" (Naylor 163). Lyautey was the first French Resident General of Morocco. Frequent uprisings occurred throughout the duration of the French protectorate in Morocco. By 1955, Mohammed V negotiated for the gradual emancipation of Morocco from France. The French-Moroccan Agreement of 1956 officially relinquished Morocco as a protectorate of France. At that point, Morocco became a constitutional monarchy.

${ }^{3}$ This quote is taken from Roosevelt's speech “On American Motherhood," which he delivered in March 1905 to the National Congress of Mothers. In the speech, Roosevelt acknowledged women's rights to education but argued that they had a national obligation to remain in the home as wife and mother.

${ }^{4}$ Frederick Wegener provides a detailed account of Wharton's “pro-imperialist" cohort in the U.S. In addition to Roosevelt, Wharton associated with Henry Cabot Lodge, George Cabot Lodge, Archibald Coolidge, and William Morton Fullerton (784).

${ }^{5}$ Wharton's letters from 1898 suggest that she didn't support the Spanish American War. According to Wegener, Wharton "objected more to the belligerence toward an esteemed European power than to an incipient colonialism on the part of the United States in Cuba" (784). 
${ }^{6}$ The advent of the steam ship accounts for a spike in American-authored travel writing from 1850-1900. In that fifty year period, 1439 books of travel were published (Schriber 148).

${ }^{7}$ The first edition of In Morocco was published in 1920 by Scribners and by Macmillan. There were two later printings, one in 1920 and another in 1925. An English edition was printed in 1927 by Jonathan Cape in London. In terms of serialization, In Morocco appeared in Scribner's Magazine from July through October 1919 in four parts. In the Yale Review, "Harems and Ceremonies" appeared in October of 1919. In 1984, Jonathan Cape's edition was re-printed. ${ }^{8}$ As Franz Fanon, Homi Bhabha, and other postcolonial scholars others have shown, colonial rule is never absolute and presents with it opportunities for colonized resistance to colonial power.

${ }^{9}$ Jacob Rama Berman defines "arabesques" as an "imitation of the original that translates its meaning into a new cultural context" (xi). These images of the "Arab" supported the "American public's taste for representations of Arabs and Islam" in popular culture which affirmed (and occasionally contradicted) the fantasy of U.S. cultural and political unity (5).

${ }^{10}$ The Algerine Spy in Pennsylvania: or, Letters Written by a Native of Algiers on the Affairs of the United States in America was anonymously published in 1787 and is credited by some for having influenced the adoption of the new U.S. Constitution in 1789. Royall Tyler's The Algerine Captive (1797) is a two-volume novel that takes the form of a fictitious memoir of protagonist Updike Underhill's experience as a slave in Algiers. Slaves in Algiers, published in 1793, is a play by Susanna Rowson. The play uses "white slavery" to highlight the freedoms enjoyed in the U.S., and emphasizes equality for women.

${ }^{11}$ Robert Smythe Hichen's The Garden of Allah sold well in the U.S. and was later made into three films (the earliest in 1916). P.C. Wren's adventure novel Beau Geste (1924) depicts the 
French Foreign Legion in North Africa and was later made into several films. Edith Maude's The Sheik (1919) depicts a white woman's solitary travel through Algeria. Each of these books and films sold well in the U.S.

12 "Maghreb" refers to Morocco, Algeria, and Tunisia and some of the Sahara (Edwards 1). I use this spelling throughout the chapter, but defer to Wharton's spelling when quoting In Morocco directly.

${ }^{13}$ There are ongoing debates regarding what geographically constitutes "North Africa." According to historian Phillip Naylor, most scholars agree that North Africa includes the Sahara and the northern land along the Mediterranean. Some consider Egypt part of North Africa, but histories of Egypt are usually associated with the histories of the Middle East region, as opposed to North Africa (Naylor 2). For my purposes, I use North Africa to refer to Morocco, Tunisia, and Algeria.

${ }^{14}$ Morocco was officially a French "protectorate," not a colony. In Morocco, General Lyautey advocated a "method of peaceful penetration and indirect rule" in Morocco (Holsington vii). Lyautey boasted that the "protectorate over Morocco was the highest form of French imperialism and the truest expression of association" rather than assimilation (Holsington 42). While this may have been the official position, the reality of French colonialism in Morocco did not match the Resident General's ideal. As Naylor points out, Lyautey exerted a "paternalist" superiority over Moroccans and "Lyautey ensured Morocco maintained its identity, or more accurately, his perception of Moroccan identity. The Resident General's proprietary and moral perspective regarding Morocco’s welfare resembled Lord Croner’s Egyptian 'burden.' Nonetheless, Lyautey's earnest enterprise tempered the inevitable colonial exploitation of Morocco" (164). 
15 Judith Funston focuses on elements of Orientalism in In Morocco in her essay "Edith Wharton's Heart of Darkness" (1988).

16 The definition of shadowland was taken from: "shadowland." Online Etymology Dictionary. Douglas Harper, Historian. 27 Feb. 2015.

<Dictionary.com/http://dictionary.reference.com/browse/shadowland $>$.

${ }^{17}$ Edith Wharton identifies as a Christian in In Morocco. However, her relationship with her faith was complicated. For a full study of Wharton's spiritual identity and its impact on her fiction see Carol J. Singley's Edith Wharton: Matters of Mind and Spirit. Cambridge: Cambridge UP, 1998.

${ }^{18}$ For more on Wharton's feminist politics in the harem see Lucas Tromly’s “The Small Talk of the Harem: Discursive Communities and Silences in Edith Wharton's In Morocco" (2009). For work on Edith Wharton's general feminist politics see Elizabeth Ammons's Edith Wharton's Argument with America (1980).

${ }^{19}$ For further resources on white slavery see Christopher Diffee "Sex and the City: The White Slavery Scare and Social Governance in the Progressive Era” in American Quarterly 57.2 (2005):411-37; Mara L. Keire "The Vice Trust: A Reinterpretation of the White Slavery Scare within the U.S. 1907-1917” in the Journal of Social History 35.1 (2001): 5-41. For more on Wharton's treatment of "white slavery" in her fiction see Jennifer Haytock's Edith Wharton and the Conversations of Literary Modernism (2001).

${ }^{20}$ It should be noted that depictions of harem varied greatly. While harems were almost always discussed within the context of sex, the actual "responses to the harem were varied and diverse depending upon the social position of the viewer" (gender, class, national affiliation, religion) (DelPlato 22) 
${ }^{21}$ There has been dozens (if not more) media reports of U.S. women (usually teenage girls) who have attempted to join Islamic terrorist organizations such as ISIL. Examples include an Associated Press report in the New York Post titled "Three U.S. Girls May Have Tried to Join ISIS" and Ben Brumfield's report for CNN titled "Girls Skipped School to Join ISIS." 


\section{Conclusion}

${ }^{1}$ Alice Fahs dedicates a few paragraphs to Craft in Out on Assignment. Craft was one of the first women to attend University of California, Berkeley and was the first woman recipient of the University Medal for earning the highest GPA in her graduating class (Fahs 267).

${ }^{2}$ In a 1902 speech regarding the admission of African American women into white women's social clubs in California, Craft argued that, "“As a citizen of America, Booker T. Washington and others of his race should have full entrée into all polite circles—white, black, or yellow"' (qtd. in Fahs 269). “"The color line,"” Craft asserted, "“was drawn by prejudice”" (qtd. in Fahs 270).

3 "Hawaii Nei" translates in English to "This beloved Hawaii." "Nei” translates in English to "this" and is used to denote love or affection for the word that precedes it. This translation is taken from: The Online Hawaiian Dictionary http://hawaiiandictionary.hisurf.com/dictionaryresults.lasso.

${ }^{4}$ Both texts include a chapter about Pauline Hopkins's writing as it related to U.S. expansion and imperialism.

${ }^{5}$ Stewart Lai's collection of letters is preserved in the archives at Howard University Library in Washing, D.C. The letters are included in the "Stewart Family Papers" collection. Carlotta Stewart is the daughter of African American lawyer and Civil Rights leader Thomas McCants Stewart. She arrived in Hawaii at age 18 in 1898. For more on the lives of the Stewart family see Albert S. Broussard's African American Odyssey: The Stewarts, 1853-1963. Lawrence: University Press of Kansas, 1998. 
${ }^{6}$ One exception is Laura R. Prieto's recent essay “A Delicate Subject: Clemencia López,

Civilized Womanhood, and the Politics of Anti-Imperialism" Journal of the Gilded Age and Progressive Era 12.2 (2013): 199-233. 


\section{Works Cited}

Abdulnadi, Rabab, Evelyn Alsultarry, and Nadine Naber. "Introduction." Arab American Feminisms: Gender, Violence, and Belonging. Eds. Rabab Abdulnadi, Evelyn Alsutarry, and Nadine Naber. Syracuse: Syracuse University Press, 2010. Xix-1. Print.

Adas, Michael. Dominance by Design: Technological Imperatives and America's Civilizing Mission. Cambridge: The Belknap Press of Harvard University, 2006. Print.

Alacrón, Norma. "Chicana Feminism: In the Tracks of the "The” Native Woman." Between Woman and Nation: Nationalisms, Transnational Feminisms, and the State. Eds. Caren Kaplan, Norma Alacrón, and Minoo Moallem. Durham: Duke University Press, 1999. Print.

Alemán, Jesse. "The Other Country: Mexico, the United States, and the Gothic History of Conquest.” Hemispheric American Studies. Eds. Caroline F. Levander and Robert S. Levine. New Brunswick, N.J.: Rutgers University Press, 2008. 75-95. Print. Agamben, Giorgio. Homo Sacer: Sovereign Power and Bare Life. Trans. Daniel Heller-Roazen. Stanford, C.A.: Stanford University Press, 1998. Print.

Ammons, Elizabeth. Edith Wharton's Argument with America. Athens: University of Georgia Press, 1980. Print.

---. Conflicting Stories: American Women Writers at the Turn into the Twentieth Century. New York: Oxford University Press, 1992. Print.

Anderson, Benedict. Imagined Communities: Reflections of the Origins and Spread of Nationalism. New York: Verso Publishing, 1983. Print.

Arnold, David. Imperial Medicine and Indigenous Societies. New York: St. Martin's Press, 1989. Print. 
Avery, Gillian. "Home and Family: English and American Ideals in the Nineteenth Century." Stories and Society: Children's Literature in its Social Context. Ed. Dennis Butts. New York: St. Martin's Press, 1992. 37-50. Print.

Balce, Nerissa S. "Savagery, Docility, and the Erotics of the American Empire." Social Text 24.2 (2006): 43-89. Print.

Bederman, Gail. Manliness and Civilization: A Cultural History of Gender and Race in the United States, 1880-1917. Chicago: University of Chicago Press: 1995. Print.

Bendixen, Alfred and Judith Hamera. "Introduction." Cambridge Companion to American Travel Writing. Eds. Alfred Bendixen and Judith Hamera. Cambridge: Cambridge University Press, 2009. Print.

Berman, Jacob Rama. American Arabesque: Arabs, Islam, and the Nineteenth-Century Imaginary. New York: New York University Press, 2012. Print.

Bhabha, Homi. The Location of Culture. 2nd Edition. New York: Routledge, 2004. Print. "bled, n." OED Online. Oxford University Press, September 2015. Web. 14 October 2015. Bly, Nellie. Six Months in Mexico (1886). Nellie Bly Collection: The Books. Ed. Tri Fritz. Bloomington, I.N.: Xlibris Publishing, 2011. Print.

---. "Champion of her Sex Susan B. Anthony." The New York World 2 Feb. 1896. Around the World in Seventy-Two Days and Other Writings. Ed. Jean Marie Lutes. New York: Penguin Books, 2014. Print.

---. "Should Women Propose?" The New York World 11 Nov. 1888. Around the World in Seventy-Two Days and Other Writings. Ed. Jean Marie Lutes. New York: Penguin Books, 2014. 122-129. Print. 
---. "The Girl Puzzle" Pittsburgh Dispatch 25 Jan. 1885. Around the World in Seventy-Two Days and Other Writings. Ed. Jean Marie Lutes. New York: Penguin Books, 2014. 4-8. Print.

"Book of the Month: Manila and the Philippines." The Phrenological Journal and Science of Health Dec. 1898: 197. Print.

Briggs, Laura. Reproducing Empire: Race, Sex, Science, and U.S. Imperialism in Puerto Rico. Berkeley: University of California Press, 2002. Print.

Brody, David. Visualizing American Empire: Orientalism and Imperialism in the Philippines. Chicago: University of Chicago Press, 2010. Print.

Brown-Benitez, Lyca. "Clemencia Lopez, Idependista." Positively Filipino: Your Window on the Filipino Diaspora. Positively Filipino Online Magazine. 13 March 2013. Web. 22 June 2015.

Brückner, Martin. "Literacy for Empire: The ABCs of Geography and the Rule of Territoriality in Early-Nineteenth-Century America." Nineteenth-Century Geographies: The Transformation of Space from the Victorian Age to the American Century. Eds. Helena Michie and Ronald R. Thomas. New Brunswick: Rutgers University Press, 2003. 172206. Print.

Cameron, Ardis. "Landscapes of Subterfuge: Working-Class Neighborhoods and Immigrant Women." Gender, Class, Race, and Reform in Progressive Era. Eds. Nancy Dye and Noralee Frankel. Lexington: University Press of Kentucky, 1991: 56-72. Print.

Canham, Stephen. "Images of Hawaii for Children: Cultural Deprivileging and Reprivileging." The Image of the Child: Proceedings of the 1991 International Conference of the Children's Literature Association at the University of Mississippi (1991): 89-99. Print. 
Carby, Hazel. Reconstructing Womanhood: The Emergence of the Afro-American Woman Novelist. Oxford: Oxford University Press, 1987. Print.

Carpenter, Frank G. "If Women Were Members of Congress" Boston Sunday Globe 10 November 1895, 20. Print.

Choy, Catherine Cenzia. Empire of Care: Nursing and Migration in Filipino American History. Durham: Duke University Press, 2003. Print.

Clough, Patricia Ticento and Craig Willse. "Beyond Biopolitics: The Governance of Life and Death." Beyond Biopolitics: Essays on the Governance of Life and Death. Eds. Patricia Ticiento Clough and Craig Willse. Durham: Duke UP, 2011. 1-18. Print.

Coffman, Tom. The Island Edge of America: A Political History of Hawaii. Honolulu: University of Hawai'i Press, 2003. Print.

Coloma, Roland Sintos. "White Gazes, Brown Breasts: Imperial Feminism and Disciplining Desires and Bodies in Colonial Encounters.” Pedagogica Historica 48.2 (2012): 243-261. Print.

Craft, Mabel. Hawaii Nei. New York: Godfrey A.S. Wieners, 1899. Print.

Delpar, Helen. The Enormous Vogue of Things Mexican: Cultural Relations between the United States and Mexico, 1920-1935. Tuscaloosa: The University of Alabama Press, 1992. Print.

DelPlato, Joan. Multiple Wives, Multiple Pleasures: Representing the Harem 1800-1877. Teaneck, N.J.: Fairleigh Dickenson University Press, 2002. Print.

Derereux, Cecily. “Women's Suffrage, Eugenics, and Eugenic Feminism in Canada." Women's Suffrage and Beyond. (1 Oct. 2013) Web. 27 June 2015. 
Domosh, Mona. "Toward a Feminist Historiography of Geography." Transactions of the Institute of British Geographies 16.1 (1991): 95-104.Print.

"Donald Trump’s Presidential Announcement Speech.” Time. Time Magazine Online. 16 June 2015. Web. 28 Aug. 2015.

Dye, Nancy. "Introduction." Gender, Class, Race, and Reform in Progressive Era. Eds. Nancy Dye and Noralee Frankel. Lexington: University Press of Kentucky, 1991: 1-10. Print.

Edwards, Brian T. Morocco Bound: Disorienting America's Maghreb, From Casablanca to the Marrakech Express. Durham: Duke University Press, 2005. Print.

Eperjesi, John R. The Imperialist Imaginary: Visions of Asia and the Pacific in American Culture. Hanover, N.H.: Dartmouth College Press, 2005. Print.

Eppler-Sanchez, Karen. Dependent States: The Child's Part in Nineteenth-Century American Culture. Chicago: University of Chicago Press, 2005. Print.

Fahs, Alice. Out on Assignment: Newspaper Women and the Making of Modern Public Space. Chapel Hill: University of North Carolina Press, 2011. Print.

Fishkin, Shelley Fisher. "Crossroads of Cultures: The Transnational Turn in American Studies.” American Quarterly. 57.1 (2005): 17-5. Print.

Foucault, Michel. The History of Sexuality: Volume 1, An Introduction. Trans. Robert Hurley. New York: Random House, 1976. Print.

---. “Society Must Be Defended" Lectures at the College De France 1975-76. Trans. David Macey. Eds. Mauro Bertani and Alessandro Fontana. New York: St. Martin's Press, 1997. Print.

Fowler, J.A. "Margherita Arlina Hamm: The World Renowned Journalist, Inheritance.” The Phrenological Journal and Science of Health Sept. 1898: 106. Print. 
Foley, Neil. Mexicans in the Making of America. Cambridge: Harvard University Press, 2014. Print.

Funston, Judith E. "In Morocco: Edith Wharton's Heart of Darkness.” Edith Wharton Newsletter 5.1 (1988): 1-12. Print.

Geiger, Jeffery. Facing the Pacific: Polynesia and the U.S. Imperial Imaginary. Honolulu: University of Hawai'i Press, 2007. Print.

Goldberg, David Theo. The Threat of Race: Reflections on Racial Neoliberalism. Malden, M.A.: Blackwell Publishing, 2009. Print.

González, Gilbert G. Culture of Empire: American Writers, Mexico, and Mexican Immigrants, 1880-1930. Austin: University of Texas Press, 2004. Print.

Goodman, Matthew. Eighty Days: Nellie Bly and Elizabeth Bisland's History Making Race Around the World. New York: Ballantine Books, 2013. Print.

Grewal, Inderpal. Home and Harem: Nation, Gender, Empire, and the Cultures of Travel. Durham: Duke University Press, 1996. Print.

Griffith, Elisabeth. In Her Own Right: The Life of Elizabeth Cady Stanton. New York: Oxford University Press, 1984. Print.

Haddad, Yvonne Yazbeck. Becoming American? The Forging of Arab and Muslim Identity in Pluralist America. Waco: Baylor UP, 2011. Print.

Haggis, Jane. "White Women and Colonialism: Towards a Non-Recuperative History." The Feminist Postcolonial Reader. Eds. Reina Lewis and Sara Mills. New York: Routledge, 2003. 161-189. Print.

Hall, Stuart. "The Question of Cultural Identity." Modernity and its Futures. Eds. Tony McGrew and Stuart Hall. Oxford: Polity Press, 1992. 273-327. Print. 
Hamm, Margherita Arlina. America's New Possessions and Spheres of Influence. New York: F. Tennyson Neely, 1899. Print.

---. Manila and the Philippines. New York: F. Tennyson Neely, 1898. Print.

---. “To Elizabeth Cady Stanton.” Current Literature XVIII.6 (1895): 526. Print.

---. "Women as Travelers: The American Woman in Action." Frank Leslie's Popular Monthly June 1899, 13. Print.

"Home Reading for Young People." The Dial: A Semi-monthly Journal of Literary Criticism, Discussion, and Information (1880-1992). Xx (August 16, 1901) 1. Print.

Howes, Craig. "Hawaii Through Western Eyes: Orientalism and Historical Fiction for Children." The Lion and the Unicorn: A Critical Journal of Children's Literature 11 (1987): 68-87. Print.

Haytock, Jennifer. Edith Wharton and the Conversations of Literary Modernism. New York: Palgrave Macmillan, 2008. Print.

Hewitt, Nancy. "Politicizing Domesticity: Anglo, Black, and Latin Women in Tampa's Progressive Movements." Gender, Class, Race, and Reform in Progressive Era. Eds. Nancy Dye and Noralee Frankel. Lexington: University Press of Kentucky, 1991: 24-41. Print.

Hoganson, Kristin. “'As Badly Off as the Filipinos': U.S. Women's Suffrage and the Imperial Issue at the Turn of the Century." Journal of Women's History 13.2 (2001): 9-33. Print. ---. Fighting for American Manhood: How Gender Politics Provoked the Spanish American and Philippine American Wars. New Haven: Yale University Press, 1998. Print. 
Hoisington, William A. Lyautey and the French Conquest of Morocco. New York: St. Martin's Press, 1995. Print.

Holland, Sharon Patricia. Raising the Dead: Readings of Death and (Black) Subjectivity. Durham: Duke UP, 2000. Print.

Hunter, F.R. "Manufacturing Exotica: "Edith Wharton and Tourism in French Morocco, 191720.” Middle Eastern Studies 46.1 (2010): 59-77. Print.

Imada, Adria L. "Hawaiians on Tour: Hula Circuits through the American Empire." American Quarterly 56.1 (2004): 111-149. Print.

“Is Islam Now Ready to Yield to Christian Influences?" Current Literature Oct. 1909. American Periodicals Series Online Web. 15 Aug. 2014.

Jacobson, Matthew Frye. Barbarian Virtues: The United States Encounters Foreign Peoples at Home and Abroad, 1867-1917. New York: Hill and Wang, 2000. Print.

Kaplan, Amy. "'Left Alone with America': The Absence of Empire in the Study of American Culture." Cultures of United States Imperialism. Eds. Amy Kaplan and Donald E. Pease. Durham: Duke University Press, 1993. Print.

---. The Anarchy of Empire in the Making of U.S. Culture. Cambridge, M.A.: Harvard University Press, 2005. Print.

Karnow, Stanley. In Our Image: America's Empire in the Philippines. New York: Random House, 1989. Print.

Kassanoff, Jennie A. Edith Wharton and the Politics of Race. Cambridge: Cambridge University Press, 2004. Print. 
Kauanui, Kēhaulani, J. Hawaiian Blood: Colonialism and the Politics of Sovereignty and Indigeneity. Durham: Duke UP, 2008. Print.

Kietrys, Kyra A. and Montserrat Linares. Women in the Spanish Novel Today: Essays on the Reflection of Self in the Works of Three Generations. Jefferson, N.C.: McFarland, 2009. Print.

Kroeger, Brooke. Nellie Bly: Daredevil, Reporter, Feminist. New York: Times Books, 1994. Krout, Mary Hannah. Alice's Visit to the Hawaiian Islands. New York: American Book Company, 1900. Print.

---. Hawaii and a Revolution: The Personal Experiences of a Correspondent in the Sandwich Islands and Subsequently. New York: Dodd, Mead, and Company, 1898. Print.

---. “The Home Circle: Travel as a Means of Liberal Education” Chicago Inter Ocean July 1893. 265. Print.

---. "The United States and Hawaii” The Chautauquan: A Weekly Newsmagazine June 1898. American Periodicals Online. 11 April 2014. 27. Web.

---. “The Woman's Kingdom: The Bachelor Girl” Chicago Inter Ocean May 1893. 11. Print.

--- . "The Women of Hawaii." The Chautauquan: Organ of the Chautauqua Literary and Scientific Circle July 1904 American Periodicals Online. 11 April 2014. 419-426. Web.

---. “Women's Vote in Cities.” Friends' Intelligencer. 24 Dec. 1892. American Periodicals Online. 11 April 2014. 49, 52. Web.

Levander, Caroline F. and Carol J. Singley. "Introduction." The American Child: A Cultural Studies Reader. Eds. Caroline Levander and Carol J. Singley. New Brunswick: Rutgers University Press, 2003. 3-12. Print. 
Lewis, Reina. Gendering Orientalism: Race, Femininity, and Representation. London:

Routledge, 1996. Print.

Lewis, Reina and Sara Mills. “Introduction.” Feminist Postcolonial Theory: A Reader. Eds.

Reina Lewis and Sara Mills. New York: Routledge, 2003. 1-25. Print.

Lopez, Clemencia. "Women of the Philippines: Address of Senorita Clemencia Lopez at the Annual Meeting of the New England W.S.A. May 29 1902.” Woman's Journal. Vol. XXXIII. No. 23. 7 June 1902. Proquest Historical Newspapers. 27 June 2015. Web.

Lowe, Lisa. Immigrant Acts: On Asian American Cultural Politics. Durham: Duke University Press, 1996. Print.

Love, Eric T. Race over Empire: Racism and U.S. Imperialism 1865-1900. Chapel Hill: The University of North Carolina Press, 2004. Print.

Lutes, Jean Marie. "Into the Madhouse with Nellie Bly: Girl Stunt Reporting in Late NineteenthCentury America.” American Quarterly 54.2 (2002): 217-253. Print.

Majaj, Lisa Sbair. "Arab Americans and the Meaning of Race." Postcolonial Theory and the U.S.: Race, Ethnicity, and Literature. Eds. Amritjit Sighn and Peter Schmidt. Jackson, Mississippi: UP of Mississippi, 2000. 320-337. Print.

Marr, Timothy. The Cultural Roots of American Islamicism. New York: Cambridge University Press, 2006. Print.

"Mary Hannah Krout." American Primary Teacher. Ed. A.E. Winship. Boston: New England Publishing Company, 1910. 208. Print.

"Mary Hannah Krout." Who Was Who in America, Volume 1. $5^{\text {th }}$ ed. 1900. Print.

“Mary Hannah Krout Dies." New York Times (June $2^{\text {nd }}$ 1927) 25. Print.

Mbembe, Achille. "Necropolitics." Public Culture 15.1 (2003): 11-40. Print. 
McClintock, Anne. Imperial Leather: Race, Gender, and Sexuality in the Colonial Contest. New York: Routledge, 1995. Print.

McGillis, Roderick. A Little Princess: Gender and Empire. New York: Twayne Publishers, 1996. Print.

McGowan, William P. “Industrializing the Land of Lono: Sugar Plantation Managers and Workers in Hawaii, 1900-1920.” Agricultural History 69.2 (1995): 177-220. Print.

Meaney, Shealeen. “'In My American Fashion': National Identity, Race, and Gender Tourism in Select Works by Zora Neale Hurston, Grace Seton-Thompson, and Zatella Turner.” Journal of Women's Studies 38.7 (2009): 765-790. Print.

Michie, Helena and Ronald R. Thomas. "Introduction.” Nineteenth-Century Geographies: The Transformation of Space from the Victorian Age to the American Century. New Brunswick: Rutgers University Press, 2003. 1-22. Print.

Mills, Sara. "Knowledge, Gender, and Empire.” Writing Women and Space: Colonial and Postcolonial Geographies. Eds. Alison Blunt and Gillian Rose. New York: The Guilford, Press, 1994. 29-51. Print.

Moallem, Minoo. "Transnationalism, Feminism, and Fundamentalism." Between Woman and Nation: Nationalism, Transnational Feminisms, and the State. Eds. Caren Kaplan, Norma Alarcon, and Minoo Moallem. Durham: Duke University Press, 199. 320-348. Print. Mohanty, Chandra Talpade. "Under Western Eyes: Feminist Scholarship and Colonial Discourse.” Dangerous Liaisons: Gender, Nation, and Postcolonial Perspectives. Eds. Anne McClintock, Aamir Mufti, and Ella Shohat. Minneapolis: University of Minnesota Press, 1997. 255-277.

Moran, Michelle T. Colonizing Leprosy: Imperialism and the Politics of Public Health in the 
United States. Chapel Hill: The University of North Carolina Press, 2007. Print.

Naylor, Phillip C. North Africa: A History from Antiquity to the Present. Austin: University of Texas Press, 2004. Print.

Newman, Louise. White Women's Rights: The Racial Origins of Feminism in the United States. New York: Oxford University Press, 1999. Print.

Nugent, Walter. Habits of Empire: A History of American Expansion. New York: Vintage Books, 2008. Print.

O’Byrne, Patricia. Post-War Spanish Women Novelists and the Recuperation of Historical Memory. Rochester, N.Y.: Tamesis, 2014. Print.

“On Behalf of Hawaiian Women.” The Woman's Journal. Vol. XXX, No. 6. 11 Feb. 1899: 20. Proquest Historical Newspapers. 15 May 2015. Web.

“Our Relations with Mexico.” Overland Monthly. Vol. XI. No. 1. July 1873: 63. American Periodicals Online. 12 August 2015. Web.

Patterson, Martha H. Beyond the Gibson Girl: Reimagining the American New Woman, 18951915. Champaign, I.L.: University of Illinois Press, 2009. Print.

Powell, E. Alexander. “The Moslem Menace.” Outlook 14 Oct. 1911. American Periodical Series Online 15 Aug. 2014. Web.

Pratt, Mary Louise. Imperial Eyes: Travel Writing and Transculturation. New York: Routledge, 1992. Print.

Rafael, Vicente. "White Love: Surveillance and Nationalist Resistance in the U.S. Colonization of the Philippine." Cultures of United States Imperialism. Eds. Amy Kaplan and Donald E. Pease. Durham: Duke University Press, 1993. 185-218. Print. 
Bebell 201

“Remarks by Mrs. Mary A. Livermore.” Report of the Fifth Annual Meeting of the New England Anti-Imperialist League. Boston: New England Anti-Imperialist League, 1903. 33-37. Print.

Roediger, David. Working Toward Whiteness: How America's Immigrants Become White. New York: Basic Books, 2005. Print.

Rich, Charlotte. "Edith Wharton and the Politics of Colonialism: The Good Public Relations of In Morocco.” Edith Wharton Review Fall (1999): 8-13. Print.

---. Transcending the New Woman: Multiethnic Narratives in the Progressive Era. Columbia: University of Missouri Press, 2009. Print.

Rihani, Ameen. “The Crisis of Islam.” Forum May 1912. American Periodical Series Online Web.15 Aug. 2014.

Roosevelt, Theodore. “On American Motherhood (1905).” The World's Famous Oration in America (1861-1905). Bartleby.com. n.d. Web. 17 July 2015.

Ross, Paul. “Mexico's Superior Health Council and the American Public Health Association: The Transnational Archive of Porfirian Public Health, 1887-1910.” Hispanic American Historical Review 89.4 (2009): 573-602. Print.

Rouse, Jacqueline A. “Atlanta’s African-American Women’s Attack on Segregation, 19001920.” Gender, Class, Race, and Reform in Progressive Era. Eds. Nancy Dye and Noralee Frankel. Lexington: University Press of Kentucky, 1991. 11-23. Print.

Ruddick, Nicholas. "Nellie Bly, Jules Verne, and the World on the Threshold of the American Age.” Canadian Review of American Studies 29.1 (1999): 1-11. Print. 
Bebell 202

Ruiz, Jason. Americans in the Treasure House: Travel to Porfirian Mexico and the Cultural Politics of Empire. Austin: University of Texas Press, 2014. Print.

Said, Edward. Covering Islam: How the Media and the Experts Determine How We See the Rest of the World. Revised Edition. New York: Vintage Books, 1997. Print.

---. Culture and Imperialism. New York: Vantage Books, 1993. Print.

---. Orientalism. New York: Vintage, 1978. Print.

Sands-O'Connor, Karen. Soon Come Home to This Island: West Indians in British Children's Literature. New York: Routledge, 2008. Print.

Schriber, Mary. Writing Home: American Women Abroad 1830-1920. Charlottesville: University of Virginia Press, 1997. Print.

Segalla, Spencer D. “Re-inventing Colonialism: Race and Gender in Edith Wharton’s In Morocco." Edith Wharton Review Fall (2001): 22-30. Print.

Sharpe, Jenny. Allegories of Empire: The Figure of Woman in the Colonial Text. Minneapolis: University of Minnesota, 1993. Print.

Silva, Noenoe K. Aloha Betrayed: Native Hawaiian Resistance to American Colonialism. Durham: Duke University Press, 2004. Print.

Singh, Rashna B. Goodly is Our Heritage: Children's Literature, Empire, and the Certitude of Character. Lanham, Maryland: The Scarecrow Press, 2004. Print.

Simour, Lhoussain. “The White Lady Travels: Narrating Fez and the Spacing of Colonial Authority." Journal of Women of the Middle East and the Islamic World 7(2009): 39-55. Print.

Singley, Carol. "Race, Culture, and Nation: Edith Wharton and Ernest Renan.” TwentiethCentury Literature 49.1 (2003): 32-45. Print. 
Skinner, Charles. "State of New York Department of Public Instruction Forty-Sixth Annual Report of the State Superintendent for the School Year Ending July 31, 1899.” Documents of the Assembly of the State of New York: One Hundred and Twenty-third Session. Albany: James N. Lyon, State Printer, 1900. Print.

Smith, Johanna M. "Constructing the Nation: Eighteenth-Century Geographies for Children." Mosaic: A Journal for the Interdisciplinary Study of Literature 34.2 (2001): 133-149. Print.

Smith, Sidonie. Moving Lives: Twentieth Century Women's Travel Writing. Minneapolis: University of Minnesota Press, 2001. Print.

Sneider, Allison S. Suffragists in an Imperial Age: U.S. Expansion and the Woman Question 1870-1929. Oxford: Oxford University Press, Print.

Spivak, Gayatri Chakravorty. "Can the Subaltern Speak?" Marxism and the Interpretation of Culture. Eds. Cary Nelson and Larry Grossberg. Chicago: University of Illinois Press, 1988. 66-109. Print.

Steadman, Jennifer Bernhardt. Traveling Economies: American Women's Travel Writing. Columbus: The Ohio State University, 2007. Print.

Stoler, Ann Laura. Carnal Knowledge and Imperial Power: Race and the Intimate in Colonial Rule. New Edition. Berkeley: University of California Press, 2002. Print.

--- "Tense and Tender Ties: The Politics of Comparison in North American History and (Post) Colonial Studies.” The Journal of American History 88.3 (2001): 829-865. Print.

Taketani, Etusko. U.S. Women Writers and the Discourses of Colonialism, 1825-1861. Knoxville: University of Tennessee Press, 2003. Print. 
“The Spread of Islam.” The New York Tribune July 1901 American Periodicals Series Online Web. 15 Aug. 2014.

“The Spread of Islam.” The Independent 9 Sept. 1909 American Periodicals Series Online Web. 15 Aug. 2014. Web.

Tromly, Lucas. "The Small Talk of the Harem: Discursive Communities and Silences in Edith Wharton's In Morocco." Studies in Travel Writing 13.3 (2009): 239-250. Print.

Truett, Samuel. Fugitive Landscapes: The Forgotten History of the U.S.-Mexico Borderlands. New Haven: Yale University Press, 2006. Print.

Tyrrell, Ian. Reforming the World: The Creation of America's Moral Empire. Princeton, N.J.: Princeton University Press, 2010. Print.

Venezky, Richard L. "Introductory Essay.” American Primers: Guide to Microfiche Collection. Ed. Richard Venesky. Bethesda, Maryland: University Publications of America. 1990. ixxxvii. Print.

Wallace, Jo-Ann. "De-Scribing The Water-Babies: 'The Child' in Post-Colonial Theory.” DeScribing Empire: Post-colonialism and Textuality. Ed. Chris Tiffin and Alan Lawson. New York: Routledge, 1994. 171-184. Print.

Ware, Vron. Beyond the Pale: White Women, Racism, and History. London: Verso, 1992. Print. Ware, Vron and Les Back. Out of Whiteness: Color, Politics, and Culture. Chicago: Chicago University Press, 2002. Print.

Webb, Charles Henry. “The New Woman.” Harper's Bazaar 19 March 1898: 264. Print. Wegener, Frederick. "'Rabid Imperialist': Edith Wharton and the Obligations of Empire in Modern American Fiction.” American Literature 72.4 (2000): 783-812. Print. 
Weheliye, Alexander G. Habeas Viscus: Racializing Assemblages, Biopolitics, and Black Feminist Theories of the Human. Durham: Duke University Press, 2014.

Wesling, Meg. Empire's Proxy: American Literatures and United States Imperialism in the Philippines. New York: New York University Pres, 2011. Print.

Wexler, Laura. Tender Violence: Domestic Visions in an Age of U.S. Imperialism. Chapel Hill: The University of North Carolina Press, 2000. Print.

Wharton, Edith. A Backward Glance. New York: D. Appleton-Century Company. 1934. Print.

--- French Ways and Their Meaning. New York: D. Appleton-Century Company. 1919. Print.

--- In Morocco. New York: Charles Scribner's Sons, 1920. Print.

--- The Letters of Edith Wharton. Eds. R.W.B. Lewis and Nancy Lewis. London: Simon \& Schuster, 1988. Print.

Yeğenoğlu, Meyda. Colonial Fantasies: Toward a Feminist Reading of Orientalism. Cambridge: Cambridge University Press, 1998. Print.

Yoshihara, Mari. Embracing the East: White Women and American Orientalism. Oxford: Oxford University Press, 2003. Print.

Zach, Karen Bazzani. Crawfordsville: Athens of Indiana. Mount Pleasant, SC., Arcadia Publishing, 2003. Print.

Ziegler, Mary. “Eugenic Feminism: Mental Hygiene, The Woman’s Movement, and the Campaign for Eugenic Legal Reform, 1900-1935.” Harvard Journal of Law and Gender 31 (2008): 211-235. Print. 